\author{
UNIVERSIDADE DE SÃO PAULO \\ ESCOLA DE COMUNICAÇÕES E ARTES \\ PROGRAMA DE PÓS-GRADUAÇÃO EM MÚSICA
}

LEANDRO QUINTÉRIO DOS SANTOS

\title{
Estratégias para a rotina de estudos do violonista: uma perspectiva baseada na aprendizagem autorregulada
}


LEANDRO QUINTÉRIO DOS SANTOS

\title{
Estratégias para a rotina de estudos do violonista: uma perspectiva baseada na aprendizagem autorregulada
}

\author{
Versão corrigida \\ (Versão original disponível na Biblioteca da ECA/USP) \\ Dissertação apresentada à Escola de Comunicações e Artes \\ da Universidade de São Paulo para obtenção do título de \\ Mestre em Artes. \\ Área de Concentração: Processos de Criação Musical \\ Linha de Pesquisa: Performance \\ Orientador: Prof. Dr. Edelton Gloeden
}

São Paulo

2017 
Autorizo a reprodução e divulgação total ou parcial deste trabalho, por qualquer meio convencional ou eletrônico, para fins de estudo e pesquisa, desde que citada a fonte.

\section{Catalogação na Publicação Serviço de Biblioteca e Documentação \\ Escola de Comunicações e Artes da Universidade de São Paulo Dados fornecidos pelo(a) autor(a)}

Santos, Leandro Quintério dos

Estratégias para a rotina de estudos do violonista: uma perspectiva baseada na aprendizagem autorregulada / Leandro Quintério dos Santos. -- São Paulo: L. Q. Santos, 2017.

117 p.: il. + DVD.

Dissertação (Mestrado) - Programa de Pós-Graduação em Música - Escola de Comunicações e Artes / Universidade de São Paulo.

Orientador: Edelton Gloeden

Bibliografia

1. Violão 2. estratégias de estudo 3. autorregulação da aprendizagem I. Gloeden, Edelton II. Título.

CDD 21.ed. - 780 


\section{FOLHA DE AVALIAÇÃO}

Nome: SANTOS, Leandro Quintério dos

Título: Estratégias para a rotina de estudos do violonista: uma perspectiva baseada na aprendizagem autorregulada

Dissertação apresentada à Escola de Comunicações e Artes da Universidade de São Paulo para obtenção do título de Mestre em Artes.

Aprovado em:

Banca Examinadora

Prof. Dr.

Instituição:

Julgamento:

Prof. Dr.

Instituição:

Julgamento:

Prof. Dr.

Instituição:

Julgamento: 


\section{AGRADECIMENTOS}

À CAPES, pelo apoio financeiro concedido durante o mestrado.

À minha família, onde encontro suporte direta ou indiretamente.

Às professoras Eliane Tokeshi e Luciane Sayuri, pelas indicações de literatura, à professora Sonia Ray, pelas sugestões na revisão do projeto de pesquisa e à Camilla Silva, pelas referências sobre a autorregulação.

Ao Edelton Gloeden, por todos os ensinamentos e incentivo ao longo desses anos.

Aos amigos da pós-graduação Cauã Canilha e Iury Cardoso, pela parceria nessa investida e a toda classe de violão da USP, pelo companheirismo nas aulas, recitais, mostras e cafés.

À Juliana, por estar sempre ao meu lado e me incentivar em todos os momentos. 


\section{RESUMO}

QUINTERIO, Leandro. Estratégias para a rotina de estudo do violonista: uma perspectiva baseada na aprendizagem autorregulada. 2017. 116 f. Dissertação (Mestrado em Música) Escola de Comunicações e Artes, Universidade de São Paulo. São Paulo, 2017.

O presente trabalho investiga estratégias para aperfeiçoar o estudo individual do violonista com base no conceito de autorregulação da aprendizagem e nas informações da literatura musical. Nas últimas décadas, pesquisas têm enfatizado a importância do aspecto qualitativo no estudo individual (Barry, 1992; Nielsen, 1999 e 2001; Williamon e Valentine, 2000; Hallam, 2001) e destacam que saber como estudar é uma habilidade fundamental para sustentar o contínuo aperfeiçoamento musical. Essa capacidade de regular o próprio estudo se relaciona com o mecanismo da autorregulação, conjunto de processos psicológicos pelos quais o ser humano regula seu comportamento. Como referência principal para o estudo desse conceito é utilizado Barry J. Zimmerman (2000, 2002) e também Mcpherson e Zimmerman (2011) que discutem a autorregulação na prática do músico. Da literatura musical as principais referências são os livros de Gerald Klickstein (2009) e dos violonistas Ricardo Iznaola (2000), Richard Provost (1992) e Lee F. Ryan (1991), que discutem vários aspectos relacionados à prática individual do músico. As informações trazidas pelos autores da área musical foram discutidas e organizadas de forma a trazer um panorama das estratégias para o aperfeiçoamento da prática e para estimular o comportamento autorregulado do estudante (de universidade ou conservatório superior). 0 trabalho incluiu também uma etapa prática, na qual as informações levantadas na parte teórica foram aplicadas na rotina de estudos pessoal. A experiência teve o objetivo de observar as implicações desta abordagem e foi registrada como um memorial de estudo através de relatórios e vídeos. Em suma, a análise dessa etapa se alinha com as evidências da pesquisa empírica, de que o engajamento do estudante em procedimentos como analise prévia da tarefa, estabelecimento de metas, planejamento, escolha de estratégias adequadas e reflexão sobre o estudo tem um impacto positivo na eficiência do aprendizado e no desenvolvimento musical.

Palavras-chave: Violão; Estratégias de Estudo; Autorregulação da Aprendizagem; Prática Instrumental 


\section{ABSTRACT}

QUINTERIO, Leandro. Strategies for the classical guitarist's practice routine: an approach based on the self-regulated learning theory. 2017, 116 f. Dissertação (Mestrado), Escola de Comunicações e Artes, Universidade de São Paulo. São Paulo, 2017.

This research explores strategies to improve the classical guitarist's individual practice based on the concept of self-regulated learning and resources from musical literature. During the last decades, a great amount of research has emphasized the relevance of qualitative aspect in music practice (Barry, 1992; Nielsen, 1999 e 2001; Williamon e Valentine, 2000; Hallam, 2001) and suggest that knowing how to practice is an essential ability to support constant musical improvement. The skill of regulating one's study is related to self-regulation mechanisms, which is a set of psychological procedures in which the human being regulates his own behavior. It is chosen, as main reference to the self-regulation study, Barry J. Zimmerman $(2000,2002)$ and also Mcpherson e Zimmerman (2011), that discusses the self-regulation in the musical activity. The main references from the musical literature are the books of Gerald Klickstein (2009) and the classical guitarists Ricardo Iznaola (2000), Richard Provost (1992), Lee F. Ryan (1991), that presents several aspects related to the musician individual practice. The knowledge brought from the authors in musical field were debated and organized in order to provide a panorama of strategies to enhance music practice and to stimulate students' self-regulated behavior (at university or conservatory level). This paper includes a practical stage as well, in which the collected information from the theoretical stage was applied to my study routine. The experiment has had the aim of observing and discussing the implications of self-regulation strategies, and it was registered as a study report through daily logs, audio recordings and videos. Lastly, the analysis and reflection of this practical process relates to the empirical research evidences, which show that the student's commitment in some procedures, such as task analysis, goal setting, planning, the choice of suitable strategies and reflection about the study, leads to a positive impact in practice efficiency and musical development.

Keywords: Classical Guitar; Practice Strategies; Self-Regulated Learning; Instrumental Practice 


\section{ÍNDICE DE FIGURAS}

Figura 1: modelo de 3 fases da autorregulação de Zimmerman $(2000,2002)$....................26

Figura 2: Modelo usado para o plano de estudos semanal.......................................................... 82

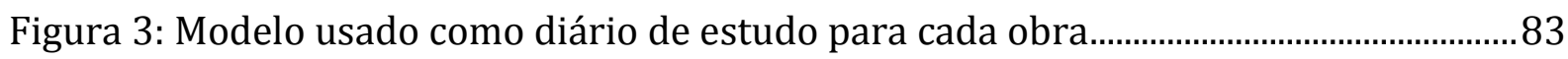

Figura 4: Quantidade de sessões de estudo (01/02 a 24/04).................................................84

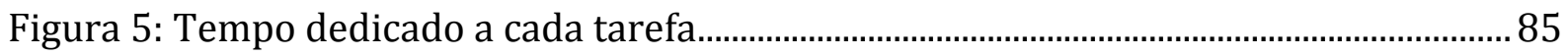

Figura 6: Tempo gasto por semana com as sessões de estudo e estimativa total do

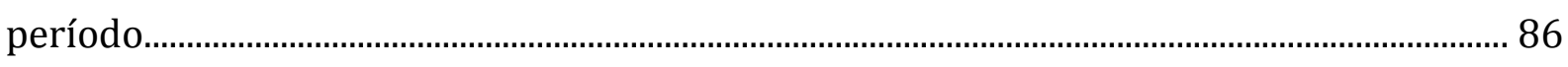

Figura 7: Comparação entre o planejamento e a execução na $5^{\underline{a}}$ semana de estudos........87

Figura 8: Distribuição do repertório na $1^{\mathfrak{a}}$ semana e na $11^{\mathfrak{a}}$, respectivamente...................88

Figura 9: Excerto do diário de estudo da Valsa-Choro 1 (Camargo Guarnieri).....................90 


\section{ÍNDICE DE TABELAS}

Tabela 1: Resumo das estratégias relacionadas às fases da autorregulação..........................70 


\section{SUMÁRIO}

INTRODUÇÃO....................................................................................................................................11

10 ESTUDO INDIVIDUAL DO MÚSICO.......................................................................................17

1.1 Pesquisas sobre a prática instrumental...........................................................................17

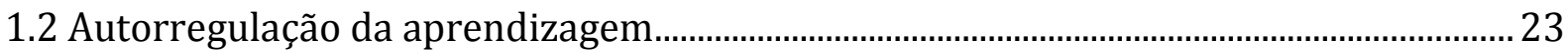

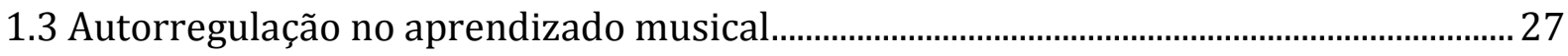

2 ESTRATÉGIAS DE APRENDIZADO NA LITERATURA MUSICAL..........................................33

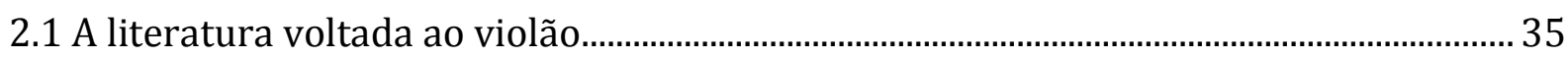

3 ORIENTAÇÕES PARA A ROTINA DE ESTUDO DO VIOLONISTA.......................................40

3.1 Relacionando a autorregulação com as estratégias apresentadas pelos autores

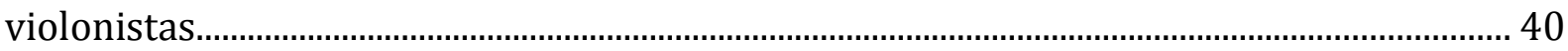

3.1.1 Estratégias na Fase de Preparação.......................................................................41

3.1.1.1 Análise da Tarefa.......................................................................................... 41

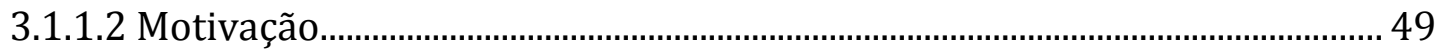

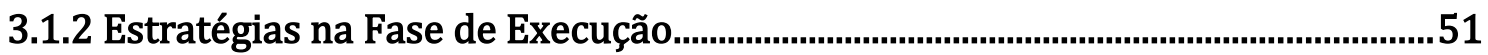

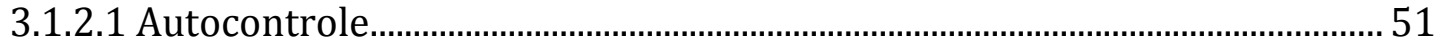

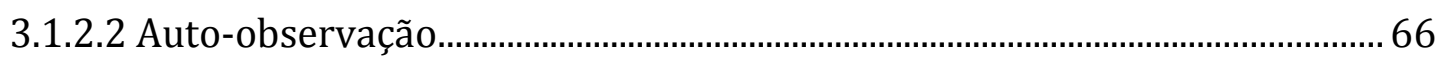

3.1.3 Estratégias na Fase de Autorreflexão......................................................................67

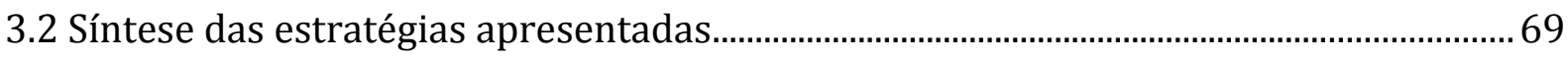

3.3 Estratégias de estudos em entrevistas com músicos avançados.......................................71

4 ETAPA PRÁTICA: APLICAÇÃO DAS ESTRATÉGIAS NA OTIMIZAÇÃO DO ESTUDO..........76

4.1 Avaliação e Planejamento inicial.....................................................................................79

4.2 Resultados e discussão sobre o processo de estudo..........................................................83

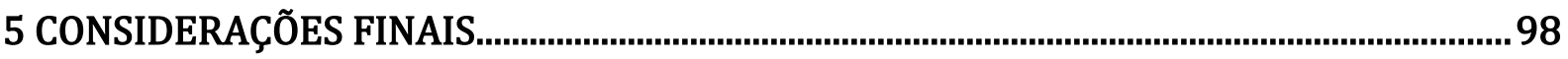

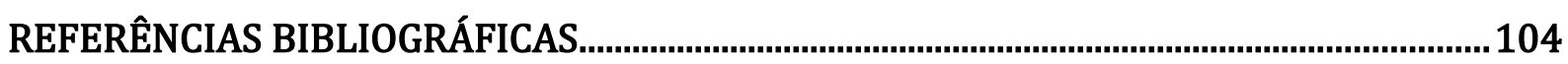

ANEXOS 



\section{INTRODUÇÃO}

O desempenho do músico depende diretamente dos hábitos criados no momento do estudo, sejam eles bons (e.g. precisão, expressividade) ou prejudiciais (e.g. tensão excessiva, memorização falha e insegurança). Dessa maneira, para que obtenha êxito na sua jornada em busca de desenvolvimento constante é crucial uma boa administração da rotina de trabalho e um amplo conhecimento de estratégias para resolver problemas.

Geralmente quando se depara com dificuldades na prática musical o estudante pensa que precisa estudar mais. As pesquisas sobre a aquisição de habilidades em música mostram que a quantidade de horas dedicadas à prática é de fato um diferencial (ERICSSON et al., 1993, SLOBODA et al. 1996). No entanto, outros fatores estão envolvidos no desenvolvimento da expertise e a qualidade do tempo investido na prática musical é um elemento determinante (WILLIAMON; VALENTINE, 2000).

Com foco no aspecto qualitativo da prática do músico, o presente trabalho tem por objetivo investigar estratégias podem ajudar a tornar a prática individual mais equilibrada e produtiva. Para esse propósito serão utilizadas como referências pesquisas na área de psicologia cognitiva e prática instrumental, além de livros escritos por autores músicos.

Os estudantes de música têm diferentes necessidades ao longo das várias etapas de formação e este trabalho volta-se principalmente ao violonista que está cursando o nível superior de ensino (universidades, conservatório superior). Esse é o momento em que o estudante certamente encontrará maior cobrança de seu desenvolvimento e precisará aperfeiçoar a autonomia no estudo, já que talvez seja um dos últimos estágios da sua formação em que terá acompanhamento regular de um professor. Além do mais, essa fase representa uma transição na qual o músico começa a ingressar nas atividades de sua profissão e a gestão do tempo se torna de suma importância em sua rotina. Para prover sua receita, geralmente este se dedica a mais de uma atividade, entre dar aulas, tocar em orquestras, grupos de câmara, fazer gravações, escrever artigos, partituras, etc. Quanto mais aprender a organizar a rotina, mais fácil será lidar com essa carreira multifacetada e continuar seu desenvolvimento artístico. 
Foi escolhido como alvo o violão por ser o instrumento do autor do trabalho, sobre o qual poderia falar com propriedade. Outro motivo é que na literatura voltada a este instrumento poucos falam de planejamento, organização, resolução de problemas e outros aspectos da prática individual. Isso também reflete um pensamento que gira em torno do ensino do instrumento no qual "o que" praticar toma às vezes maior destaque do que "como" praticar. Por essa razão, os principais autores violonistas utilizados foram aqueles que mais abordam aspectos do estudo individual, enfatizando a importância de uma rotina bem estruturada e da prática consciente para o aperfeiçoamento técnico e artístico.

É importante salientar que esta pesquisa não vem com o intuito de criar uma sistematização para o estudo do instrumento, processo este que depende de inúmeras variáveis além da criatividade e inventividade inerentes a toda arte. Várias pesquisas citadas ao longo do texto mostram a grande influência que as diferenças individuais exercem no aprendizado e não seria possível pensar em uma só abordagem servindo a todos. Sendo assim, o estudo da autorregulação da aprendizagem e seu papel no aprendizado musical será fundamental. A autorregulação é um constructo da psicologia que diz respeito aos processos pelos quais as pessoas controlam o próprio comportamento e uma das teorias que estuda este mecanismo é a Teoria Social Cognitiva, de Albert Bandura (1986 apud AZZI, 2015¹). Esta teoria propõe que os indivíduos podem exercer papel ativo na regulação de seu comportamento e que este não é produto apenas de variáveis externas, mas sim da interação entre influências ambientais, comportamentais e pessoais. Trabalhos sobre a autorregulação mostram que ela tem um importante papel no desempenho acadêmico dos estudantes e apontam para o potencial de se estimular esse processo na aprendizagem.

As principais referências para entender esse conceito foram publicações de Azzi e Polydoro (2009) e o livro Teoria Social Cognitiva: conceitos básicos (BANDURA; AZZI; POLYDORO, 2008), uma importante referência do assunto em língua portuguesa. Além disso, foi utilizado Zimmerman $(2000,2002)$ cujo trabalho que se baseia também na Teoria Social Cognitiva, e Mcpherson e Zimmerman (2011), que falam sobre a autorregulação da aprendizagem na prática musical. Várias outras pesquisas recentes que investigam os processos da autorregulação na atividade musical deram suporte a

1 BANDURA, A. Social foundations of thought and action: A social cognitive theory. Englewood Cliffs, NJ: Prentice-Hall, 1986. 
essa etapa (por exemplo: NIELSEN, 2001; LEON-GUERRERO, 2008; MIKSZA, 2011, 2013; HATFIELD; LEMYRE, 2016).

Há vários tópicos abordados pela pesquisa sobre a prática individual e aprendizagem musical (e.g. leitura à primeira vista, memorização, preparo para o palco, etc) e há uma diversidade de trabalhos sobre o assunto. Com os trabalhos de Gabrielsson (2003) e Barros (2008), que apresentam um levantamento da pesquisa empírica em música, com reflexões críticas e caminhos de investigação, foi possível ter um panorama das pesquisas já realizadas. Gabrielsson propõe uma categorização dos temas e mostra dados quantitativos a respeito dos principais tópicos investigados nas décadas anteriores. Barros faz um levantamento mais detalhado a partir de uma das categorias propostas por Gabrielsson, o Planejamento da Execução Instrumental, que inclui trabalhos sobre comportamentos no estudo, organização da prática, estratégias de estudo e o processo de aprendizagem. Como a presente pesquisa se insere nessa categoria as principais referências são autores que tratam desses assuntos.

O livro de Williamon (2004) é outra importante referência no que diz respeito a estratégias para o desenvolvimento musical e traz textos de especialistas que discutem, por exemplo, estratégias para prática individual, memorização, prática de música de câmara e leitura à primeira vista. Um dos textos utilizados é o de Jorgensen (2004) que discute o estudo como uma forma de autoensino, onde o músico atua como seu próprio professor ao guiar seu estudo individual. Baseado também no conceito de autorregulação, o autor apresenta estratégias para diversos aspectos da prática musical.

A pesquisa de autores instrumentistas considerou trabalhos não apenas voltados ao violão, mas também de piano e violino, que já possuem uma longa tradição de ensino e grandes professores como referência. Obviamente há muitos aspectos técnicos específicos, mas em alguns deles é possível encontrar orientações sobre planejamento e estratégia de estudos, tais como Gieseking-Leimer (1972) e José Alberto Kaplan (1987) voltados ao piano, ou Carl Flesch (1939), Ivan Galamian (1962) e Robert Gerle (1983) direcionados ao violino.

Com relação aos violonistas, são importantes os livros de Ryan (1991), Iznaola (2000) e Provost (1992), que tratam de assuntos que vão além do aspecto técnico. Ryan aborda a prática de forma holística e traz estratégias para resolver problemas durante o estudo, preparação individual e performance. Iznaola e Provost são os autores que mais 
falam de organização do estudo e tratam de questões importantes da preparação para performance do violonista.

Klickstein (2009), embora não seja voltado especificamente ao violão, é outra importante referência que abrange diversas orientações relacionadas à rotina do músico, incluindo interpretação, musicalidade, expressão, preparação para a performance, ansiedade de palco, cuidados com o corpo, carreira musical e criatividade. Em seu livro, há uma seção dedicada ao estudo individual particularmente relevante para esta pesquisa, na qual são abordados assuntos relativos à organização da sessão de estudos, com sugestões para estruturar a prática.

Grande parte dos trabalhos utilizados como referência são oriundos de centros de pesquisa, universidades ou periódicos internacionais. A pesquisa sobre a performance musical no Brasil, de modo geral, ainda tem pequena participação no mundo acadêmico, se comparada com musicologia ou educação musical, por exemplo. Os trabalhos de pós-graduação nessa área que de fato se alinham com o trabalho do performer ainda são poucos ou mal divulgados, como apontam Ray e Borém (2012, p. 140) em um levantamento sobre a pesquisa em performance no país entre 2000 e 2012.

Apesar disso, é possível encontrar trabalhos recentes de pós-graduação e em periódicos nacionais que abordam a preparação da performance do violonista. Como exemplo, é possível citar: Araújo (2010), Kaminski (2012), Salgado (2015), Mello (2015), e Silva e Scarduelli (2013). Estes trabalhos têm levantado reflexões sobre abordagem de obras novas, processo de digitação, técnicas estendidas, estratégias de estudo e autorregulação na prática individual. Um dos autores que traz informações relevantes para esta pesquisa é Mendonça (2015). Seu trabalho estudou o uso de representações mentais na preparação para a performance e inclui entrevistas com alguns dos maiores nomes do violão (no Brasil e exterior), nas quais se pode conhecer aspectos do processo de estudo desses importantes violonistas. Vale citar também o trabalho de Silva (2016), que discute a autorregulação e traz propostas para o ensino do violão nos cursos de licenciatura a partir desse conceito, com objetivo de promover o conhecimento de estratégias de aprendizagem nos educadores.

A partir dos dados das etapas anteriores, as orientações da pesquisa empírica e dos autores instrumentistas foram organizadas de forma a servir como um panorama de 
estratégias para o estudo individual. Os procedimentos estão relacionados na tabela 1 (p.71) tendo como referência as etapas da aprendizagem autorregulada.

Como o trabalho está inserido na área da pós-graduação em performance, a parte prática é também produto da pesquisa e deve estar relacionada à investigação teórica. Sendo assim, as estratégias levantadas no trabalho foram aplicadas na rotina de estudos pessoal com o intuito de observar a funcionalidade desses procedimentos. 0 principal questionamento que alimenta esta etapa é se é possível tornar o aprendizado mais produtivo através do planejamento, organização, uso de estratégias adequadas e reflexão sobre a rotina de estudo.

É importante salientar que esta etapa prática não representa uma pesquisa experimental, já que para isso seria necessário ter delineado de maneira clara e coerente os procedimentos metodológicos, tais como a seleção dos aspectos a se avaliar, a definição dos métodos de avaliação e o controle das variáveis. Apesar disso, as estratégias foram aplicadas em uma rotina de estudos para violão de uma maneira o mais semelhante possível de uma situação real, incluindo, por exemplo, desenvolvimento de repertório novo, repertório antigo, trabalho técnico e preparação para performance. Este processo foi registrado em um memorial de estudo com relatórios e gravações, permitindo assim a avaliação e discussão posterior dos resultados desta experiência, observando o que não saiu de acordo com o plano, as adaptações realizadas, além de possíveis vantagens/desvantagens dessa abordagem.

Sendo assim, o trabalho inicia com um breve panorama da pesquisa em prática instrumental no $1^{\mathrm{o}}$ capítulo. Nesta parte é elucidado o conceito da autorregulação da aprendizagem, que tem sido usado como referência em pesquisas sobre o comportamento dos músicos em situações de estudo individual.

No $2^{\circ}$ capítulo estão as referências da área musical, com destaque para os métodos de violão e livros que abordam a prática do violonista.

Partindo do modelo de aprendizagem autorregulada, o $3^{\text {o }}$ capítulo reúne uma seleção das estratégias apresentadas pelos autores violonistas. A ênfase nessa etapa foi nas estratégias que tem relação com os processos da autorregulação e que podem colaborar no aperfeiçoamento do estudo individual. 
Por fim, o $4^{\circ}$ capítulo descreve os procedimentos realizados na etapa prática deste trabalho. São detalhadas as estratégias utilizadas, o repertório trabalhado, as ferramentas de suporte e discutidos os pontos positivos e dificuldades dessa abordagem. Há também material anexo, com excertos dos planos de estudo, relatórios e vídeos realizados no processo. 


\section{ESTUDO INDIVIDUAL DO MÚSICO}

\subsection{Pesquisas sobre a prática instrumental}

A ideia de que é necessário praticar para alcançar proficiência em uma atividade é muito antiga e, pelo menos dentro do último século a pesquisa científica tem se voltado a entender esse processo em áreas como esporte e música (JORGENSEN, 2004, p. 87). Praticar para desenvolver a habilidade musical envolve vários aspectos que vão além do controle motor, o que torna a música uma das atividades humanas mais complexas. Os músicos praticam com diversos objetivos: adquirir, desenvolver ou manter a técnica, aprender novas músicas, trabalhar a interpretação, memorização e o preparar-se para a performance (BARRY; HALLAM, 2002, p.155).

Ao executar uma música, um indivíduo coloca em operação uma tarefa previamente compreendida e armazenada em sua memória através de extensa prática, com uma diversidade de informações, incluindo desde movimentos finos do aparelho motor a padrões sonoros abstratos da linguagem musical. Nesta atividade estão complexamente envolvidos os processos da cognição ${ }^{2}$ humana, como a percepção visual, auditiva e tátil, além dos recursos da atenção. Somados a isso, estão os aspectos emocionais, relacionados não apenas ao significado do discurso musical a qual está comunicando, mas também à sua motivação e à ansiedade na performance.

Para atingir um alto nível de proficiência de performance musical com fluidez e naturalidade é necessário muito trabalho. Esta longa jornada da aquisição de habilidades é uma atividade que tem sido estudada por pesquisadores de áreas da psicologia, neurociência e educação, a fim de entender como a mente humana processa o aprendizado e como seria uma prática eficiente para o desenvolvimento da expertise. Ao estudar vários aspectos da prática musical a pesquisa científica tem levantado informações que raramente são registradas/verbalizadas pelos músicos ou que nunca foram observados sistematicamente (como a preparação para um concerto ou o processo de memorização de uma peça). A investigação desses temas se intensificaram

2 Cognição é uma das faculdades do homem que o permite adquirir, compreender e elaborar conhecimento. Consiste em processos mentais complexamente interligados que vão além da percepção sensorial. Estes processos permitem a realização de atividades abstratas e complexas, como a linguagem, o raciocínio, resolução de problemas, criatividade, a execução de tarefas elaboradas e a própria consciência. Pode-se ler mais sobre em Sternberg (2010) e Sloboda (2005). 
nas últimas décadas do século $\mathrm{XX}$, certamente devido às novas possibilidades tecnológicas, como o registro audiovisual, programas de computador para a análise dos dados e o próprio desenvolvimento da pesquisa na área de psicologia da música, como aponta Barros (2015, p. 288).

Há vários aspectos da atividade musical sendo estudados pela pesquisa empírica. Gabrielsson (2003), um dos primeiros pesquisadores a realizar um mapeamento desses trabalhos, organizou-os em 10 linhas de pesquisa de acordo com a temática: planejamento da performance, leitura à primeira vista, improvisação, feedback na performance, processos motores, medição da performance, modelos de performance, aspectos físicos, aspectos psicológicos/sociais e avaliação da performance. A este trabalho interessa a categoria planejamento da performance, cujas pesquisas abordam: sistematização e organização consciente da prática (estratégias de estudo, metacognição, prática efetiva); a maior relevância da qualidade e conteúdo da prática em relação à quantidade; a maneira como a representação mental e a estrutura da música influenciam a execução e organização da prática; as etapas e o processo de aprendizagem que levam a uma execução de nível avançado (BARROS, 2015, p. 286).

A pesquisa sobre a prática instrumental, em sua maioria, trata do aprendizado dentro da música clássica ocidental e investiga a preparação para a performance e desenvolvimento de habilidades tanto no músico profissional quanto nos estudantes em diversos níveis. Barros (2015, p. 289) explica que a temática desses trabalhos gira em torno de 3 eixos: 1) comportamento durante o estudo, organização, características e tipos de prática; 2) estratégias de estudo; 3) a representação mental da música e processos cognitivos envolvidos na memorização.

Embora com diferentes ideias e abordagens, de maneira geral, as pesquisas que abordam o aprendizado de habilidades na prática instrumental enfatizam dois elementos importantes para o desenvolvimento da expertise em música: a quantidade e a qualidade no estudo.

Um dos mais importantes referenciais nesse assunto é o trabalho de Ericsson et al. (1993) cujos resultados mostram que o nível de proficiência tem relação direta com a quantidade de prática formal realizada por um indivíduo. Em um estudo com violinistas de diversos níveis foi comparado a quantidade de horas de prática e os mais avançados tinham, em média, 10 mil horas acumuladas de prática formal aos 21 anos. Sloboda 
(1996) apresenta outros resultados que corroboram com essa ideia, comprovando que há uma forte e positiva relação entre a quantidade de prática formal realizada por um estudante e o nível de desempenho. De maneira geral, esses trabalhos indicam que o acúmulo de prática ao longo de vários anos, o início cedo da aprendizagem ao instrumento e a regularidade semanal está fortemente relacionada a altos níveis de expertise.

Isso não significa que se um indivíduo se empenhar em realizar uma grande quantidade de horas de prática ele vai se tornar um expert. Os resultados positivos dependem de vários fatores, que vão desde os recursos disponíveis (e.g. ambiente estimulante, bons professores, material disponível, instrumento utilizado) até aspectos motivacionais.

Outros autores voltaram a atenção para o conteúdo e a qualidade da prática, questionando se a quantidade seria o principal pré-requisito para a expertise. Williamon e Valentine (2000), por exemplo, observaram que apesar das horas acumuladas ao longo de anos de prática estarem associados a níveis avançados, o montante de horas na preparação para uma performance específica não determinava a qualidade desta. 0 diferencial nestes casos não era a quantidade, mas a maneira como a preparação para a performance foi organizada e planejada.

Essas pesquisas tratam do que é chamado de prática deliberada, uma maneira específica de estudar, na qual se busca o desenvolvimento de elementos específicos da atividade musical e demanda esforço consciente. O termo prática deliberada foi introduzido por Ericsson et al. (1993) e pode ser definido como uma:

(...) atividade estruturada, geralmente projetada por professores ou treinadores com o objetivo explícito de elevar o nível da performance de um indivíduo. Ao contrário de trabalhar e tocar, requer a elaboração de metas específicas a desenvolver e o monitoramento de vários aspectos da performance. Além disso, a prática deliberada envolve a superação dos limites individuais, o que exige plena concentração e esforço. Consequentemente, só é possível dedicar-se a essas atividades por um curto período de tempo, até que seja necessário o descanso e a recuperação. (ERICSSON; LEHMANN, 1999 apud LEHMANN; JORGENSEN 2012, p. 678). ${ }^{3}$

\footnotetext{
3 Tradução do autor: structured activity, often designed by teachers or coaches with the explicit goal of increasing an individual's current level of performance. In contrast to work and play, it requires the generation of specific goals for improvement and the monitoring of various aspects of performance. Furthermore, deliberate practice involves trying to exceed one's previous limits, which requires full concentration and effort. Consequently, it is only possible to engage in these activities for a limited amount of time until rest and recuperation are needed.
} 
Ainda segundo Ericsson et al. (1993), a prática deliberada está sob a influência de três aspectos:

- Recursos: o qual inclui fatores como ambiente estimulante, bons professores, material disponível, instrumento utilizado e situações favoráveis ao desenvolvimento;

- Esforço: a prática demanda esforço e há um limite de quanto tempo é possível praticar com qualidade. Esse limite está relacionado tanto ao aspecto físico quanto à concentração, por isso a importância das pausas e de realizar sessões de estudos não muito longas;

- Motivação: é preciso haver outra motivação além da prática em si, uma vez que, ao contrário da prática recreativa, essa não é necessariamente prazerosa, pois tem metas específicas e o resultado vem a longo prazo.

Os iniciantes podem ter dificuldade em praticar dessa forma, uma vez que têm menor conhecimento de estratégias básicas de aprendizado e poucos parâmetros para julgar seu desempenho no estudo. Por esse motivo, dependem bastante dos professores para instruí-los em como estudar e também dos pais, que podem colaborar nesse aspecto. Outro papel importante de ambos é o da motivação: praticar com objetivo de desenvolver habilidades não é por si só algo gratificante e no início do aprendizado musical o estímulo externo se faz necessário, até que os jovens encontrem motivação por si próprios para a atividade. Quando o estudante progride, a ideia é que ele se torne mais autônomo com relação à prática deliberada.

Um ponto importante sobre a pesquisa empírica destacado por Lehmann e Jorgensen (2012, p. 678-679) é que há uma dificuldade em observar detalhadamente o comportamento dos músicos durante o estudo e identificar, por exemplo, em que medida ele está empregando a prática deliberada, trabalhando para melhorar algum aspecto ou simplesmente tocando sem a devida concentração. Ainda que haja limitações, o comportamento no estudo tem sido tema de várias pesquisas experimentais, como em: Gruson (1988 apud LEHMANN; JORGENSEN, 2012, p. 679) que observou pianistas de diversos níveis e os procedimentos que usavam durante o ensaio; Barry (1992 apud BARRY e HALLAM, 2002, p.154) sobre a eficiência da abordagem estruturada da prática; Nielsen (1999), analisando diferentes estratégias de estudo empregadas por dois 
organistas na preparação de uma música; Maynard (2006 apud PARKES, 2010) examinando o uso da repetição como ferramenta de estudo, além de vários outros ${ }^{4}$ que tratam do preparo para a performance, memorização e estratégias de ensaio. Apesar das dificuldades em se analisar o que os músicos fazem e pensam ao estudar, estes trabalhos mostram que a maneira como a prática é realizada tem importante impacto no desenvolvimento da habilidade musical e na performance.

Outro conceito levantado é de que a prática deve ser efetiva, sendo esta baseada na economia de tempo e esforço em busca de um objetivo (HALLAM ${ }^{5}, 1997$ apud SANTOS; HENTSCHKE, 2009, p. 73), ou em características essenciais como concentração, estabelecimento de metas possíveis, autoavaliação, o uso de estratégias flexíveis e a criação de um visão global da obra a ser preparada (CHAFFIN; LEMIEUX, 2004). Dentro dessa postura frente a situação de prática, os músicos deveriam usar diferentes estratégias (JORGENSEN, 2004), e quanto mais diverso seu conhecimento e experiência em empregar procedimentos para realização do estudo, mais produtivo este será.

Por estratégias de estudo pode-se entender como pensamentos ou comportamentos que os músicos empregam durante a prática com o objetivo de influenciar seu estado motivacional e afetivo, ou a maneira como selecionam, organizam, integram e ensaiam novos conhecimentos e habilidades (WEINSTEIN; MAYER 1986 apud JORGENSEN, 2004, p. 856 ). Por exemplo, o estudo com o metrônomo para controle do andamento seria um tipo de estratégia de comportamento; já o planejamento, uma estratégia de pensamento.

Não há ainda uma estrutura teórica bem delineada para a pesquisa sobre estratégias de estudo em música e costuma-se importar referências de outras áreas. Essa falta de um sólido referencial teórico é, inclusive, uma das críticas com relação à pesquisa em prática instrumental (como fazem Barros 2008, ou Nielsen, 1999). Apesar

4 Ver Barros, 2008 e 2015 para discussão sobre a pesquisa empírica em música nas últimas décadas.

5 HALLAM, S. Approaches to instrumental music practice of experts and novices: Implications for education. In: Does practice make perfect? JøRGENSEN, H; LEHMANN, A. C. (Ed.). Oslo: Norges musikkhøgskole, p. 89-107, 1997.

6 WEINSTEIN, C.; MAYER, R. The Teaching of Learning Strategies. In: WITTROCK, M. (Ed.). Handbook of Research on Teaching, Macmillan, New York, p. 315-327, 1986. 
disso, há algumas propostas: Nielsen (1999), por exemplo, apresenta duas categorias ${ }^{7}$ estratégias primárias e estratégias de suporte. As estratégias primárias atuam diretamente no aprendizado, estando ligadas ao processamento cognitivo do material (como compreensão e memorização). As estratégias de suporte atuam indiretamente, focando no estado mental (administração da concentração, da ansiedade, da motivação, uso eficiente do tempo).

Jorgensen (2004) apresenta outra proposta e classifica as estratégias em um modelo cíclico de aprendizado que é baseado na ideia de autoensino, discutida por alguns pedagogos da prática instrumental (como Ivan Galamian, 1964) e psicólogos da educação. Dessa forma, durante o estudo, o estudante deve agir como seu próprio professor, sendo responsável pelo monitoramento do seu trabalho e resolução de problemas. Baseado nessa ideia de aprendizagem cíclica, Jorgensen fala em diferentes estratégias que podem contribuir para a eficiência do estudo e as organiza em quatro tipos: planejamento, execução, avaliação e metacognição.

O uso de estratégias adequadas é fundamental para atingir os resultados desejados durante o estudo. No entanto, as estratégias por si só não são garantia de um bom desenvolvimento. Não há uma correspondência direta entre o uso de uma determinada estratégia e o sucesso na performance, já que os resultados de sua utilização dependem da adequação às variáveis de contexto e características pessoais (HALLAM, 1995 apud JORGENSEN, 2004, p. 98).

A forma como os músicos utilizam as diferentes estratégias varia de acordo com nível, características individuais e particularidades de cada instrumento. Por esse motivo os autores têm enfatizado a importância da metacognição, que seria o conhecimento sobre os seus processos cognitivos e sobre o aprendizado em si (JORGENSEN, 2004; HALLAM; BAUTISTA, 2012). As habilidades metacognitivas incluem o conhecimento do que é necessário para realizar uma tarefa, a sua capacidade de realizá-la, a consciência das próprias dificuldades e facilidades e as várias estratégias possíveis de planejamento, monitoração e avaliação do ensaio, envolvendo uma ampla

7 A referência teórica utilizada pela autora para essas categorias é Dansereau (1985) - teórico sobre aprendizado em outras áreas: DANSEREAU, D. F. Learning Strategy Research. In SEGAL, J. W.; CHIPMAN, S. F; GLASER, R. (Eds.). Thinking and Learning Skills, vol. 1: Relating Instruction to Research, New Jersey: Erlbaum, 1985. pp. 209-239 
capacidade de reflexão sobre seu próprio aprendizado, da sua motivação e a superação de limites.

Um estudo realizado com músicos profissionais e estudantes para investigar o desenvolvimento da metacognição e estratégias no preparo para a performance mostrou que havia diferença inclusive entre os músicos mais avançados com relação ao uso de estratégias, na formulação de interpretação, no conteúdo e na organização do estudo (HALLAM, 2001). Essa variedade se dava em função do que cada músico julgava necessário para si, o que evidencia sua capacidade metacognitiva mais desenvolvida. Na prática dos estudantes também era evidente o uso de estratégias mas de forma menos desenvolvida e sem foco bem definido em melhorar a performance. Dentre eles, os que apresentavam maior nível de expertise, mostraram maior uso do planejamento para completar as tarefas, identificar dificuldades, concentrar esforços para resolvê-las.

Essa habilidade de administrar seu próprio estudo está relacionada ao conceito de autorregulação, que vem da psicologia comportamental e tem sido visto como um importante elemento para a aprendizagem. Quanto maior a capacidade dos estudantes controlarem sua própria prática, melhor administram as diversas variáveis para otimizar o aprendizado (HALLAM; BAUTISTA, 2012, p. 662). Apesar de ainda ser recente na área de música, trabalhos sobre o assunto enfatizam que os estudantes podem tornar seu estudo mais produtivo ao se utilizar dessas estratégias autorreguladoras (NIELSEN, 2001; HALLAM, 2001; MCPHERSON; ZIMMERMAN, 2011; DOS SANTOS; GERLING, 2011).

\subsection{Autorregulação da aprendizagem}

A autorregulação é um processo que diz respeito à maneira como os indivíduos controlam seu comportamento e tem sido estudada por várias frentes da psicologia. Uma destas é a Teoria Social Cognitiva, do psicólogo Albert Bandura, a qual postula que o comportamento humano "é determinado a partir da interação contínua e recíproca entre as influências ambientais, pessoais e comportamentais: o modelo triádico" (AZZI; POLYDORO, 2008 p.151). Para Bandura "o homem é um ser capaz de exercer um papel ativo em sua própria história, concepção formulada sob a denominação de agência pessoal" (AZZI; POLYDORO, 2008 p.150). Isto é possível através de algumas 
características humanas, dentre as quais a capacidade de autorregulação é uma das principais.

De acordo com Azzi e Polydoro:

A autorregulação é um processo consciente e voluntário de governo, pelo qual possibilita a gerência dos próprios comportamentos, pensamentos e sentimentos, ciclicamente voltados e adaptados para obtenção de metas pessoais e guiados por padrões gerais de conduta (...) Trata-se de um fenômeno multifacetado que opera por meio de processos cognitivos subsidiários, incluindo automonitoramento, julgamentos autoavaliativos e autorreações (2009, p. 75).

Este processo faz parte do comportamento de todos os indivíduos, em maior ou menor grau. Contudo, não é algo mecânico, linear ou automático: quanto mais diversificada a atividade e as interações das variáveis, mais complexo ele será.

A pesquisa sobre a autorregulação tem vários focos, como a saúde, estudando como as pessoas a regulam seu comportamento na promoção do bem-estar; ou na educação, investigando o ensino na perspectiva dos alunos e de que forma estes podem exercer um papel mais ativo no aprendizado. 0 estudo desse mecanismo na aprendizagem conta com várias teorias e modelos sobre o seu funcionamento, como por exemplo as propostas de Paul Pintrich ${ }^{8}$ (2000), Barry Zimmerman (2000) ou Pedro Rosário $^{9}$ (2004), segundo explicam Polydoro e Azzi (2009).

Os estudos sobre a autorregulação no contexto educacional têm mostrado o importante papel que os mecanismos desse processo desempenham no sucesso acadêmico dos estudantes. É uma ferramenta que vai ao encontro das propostas discutidas pelos educadores, entendendo que o aluno não deve apenas receber conhecimento, mas também precisa ser instigado a uma postura crítica, para fazer diferentes associações entre os conhecimentos, aplicar o que sabe a novas situações e continuar aprendendo ao longo de sua vida. Em suma, o estudante autorregulado é aquele que:

(...) aprendeu a planejar, controlar e avaliar seus processos cognitivos, motivacionais, afetivos, comportamentais e contextuais; possui autoconhecimento sobre o próprio modo de aprender, suas possibilidades e

8 PINTRICH, P. R. The role of goal orientation in self-regulated learning. In: BOEKAERTS, M.; PINTRICH, P. R.; ZEIDNER, M. (eds.) Handbook of self-regulation, Academic Press, 2000, p. 452502.

9 ROSÁRIO, P. Estudar o Estudar: As (Des)venturas do Testas. Porto, Porto Editora, 2004. 
limitações. Com tal conhecimento, o estudante controla e regula o próprio processo de aprendizagem em direção aos objetivos e metas. (MONTALVO; TORRES, 2004 apud POLYDORO; AZZI, 2009, p. 79).

Para este trabalho será usado o modelo de Barry Zimmerman $(2000,2002)$, que é baseado na teoria social cognitiva de Albert Bandura. Além disso, o autor já se voltou à investigação sobre a autorregulação no aprendizado musical (MCPHERSON e ZIMMERMAN, 2002, 2010) sendo uma referência recorrente em pesquisas recentes sobre a prática instrumental (LEON-GUERRERO, 2008; MIKSZA, 2011, 2013; HATFIELD, LEMYRE 2016).

O modelo de Zimmerman $(2000,2002)$ inclui 3 fases em um processo cíclico: a fase de preparação, em que são planejados objetivos e escolhidas as estratégias; fase de execução que compreende a realização dos planos traçados, e fase de autorreflexão, na qual são avaliados e julgados os resultados obtidos. Em cada fase há também outros subprocessos que influenciam o todo, conforme detalhado a seguir:

- A FASE DE PREPARAÇÃO inclui duas categorias fortemente conectadas: análise da tarefa e crenças de automotivação. A primeira engloba elementos como o estabelecimento de metas, planejamento e seleção de estratégias. A segunda envolve os processos de autoeficácia, expectativa de resultados, meta de realização e motivação intrínseca, que influenciam diretamente o desenvolvimento do aprendizado.

- A FASE DE EXECUÇÃO, engloba dois tipos de processos: autocontrole e autoobservação (ou automonitoramento). Os processos de autocontrole ajudam a manter o foco na execução das tarefas e são realizados através de: autoinstrução, imagens mentais, foco de atenção e estratégias de ensaio. Os processos de autoobservação permitem reconhecer se houve progresso no que está trabalhando ou se o resultado foi alcançado e podem incluir autorregistro e autoexperimentação.

- A FASE DE AUTORREFLEXÃO, inclui dois tipos de processos que são estreitamente ligados: autojulgamento e autorreação. Os processos de autojulgamento envolvem a autoavaliação e atribuições de causa. A autoavaliação, talvez o principal desta fase, consiste na avaliação dos resultados obtidos em comparação com o que se esperava alcançar (esse parâmetro pode ser em relação à performances anteriores, a um padrão estabelecido ou a outras 
pessoas). As atribuições de causa referem-se ao que o indivíduo atribui como motivos causadores dos resultados e se as causas são tangíveis e passíveis de controle ou alteração. 0 outro processo principal, a autorreação, envolve as reações aos processos de autojulgamento, compreendendo a autossatisfação e as reações adaptativas/defensivas. Quando o julgamento pessoal de seu próprio desempenho traz bom resultado, a satisfação positiva leva o estudante a se manter cada vez mais engajado no aprendizado, elevando o interesse intrínseco na atividade, a percepção de autoeficácia e estimulando a tarefas mais desafiadoras. As reações adaptativas direcionam positivamente o estudante a novas ou melhores formas autorregular, como revisar e/ou escolher outras estratégias mais eficazes; ao passo que as defensivas levam o estudante a se proteger de novas falhas, procrastinando e talvez evitando outras oportunidades de aprendizado.

Figura 1: modelo de 3 fases da autorregulação de Zimmerman $(2000,2002)$

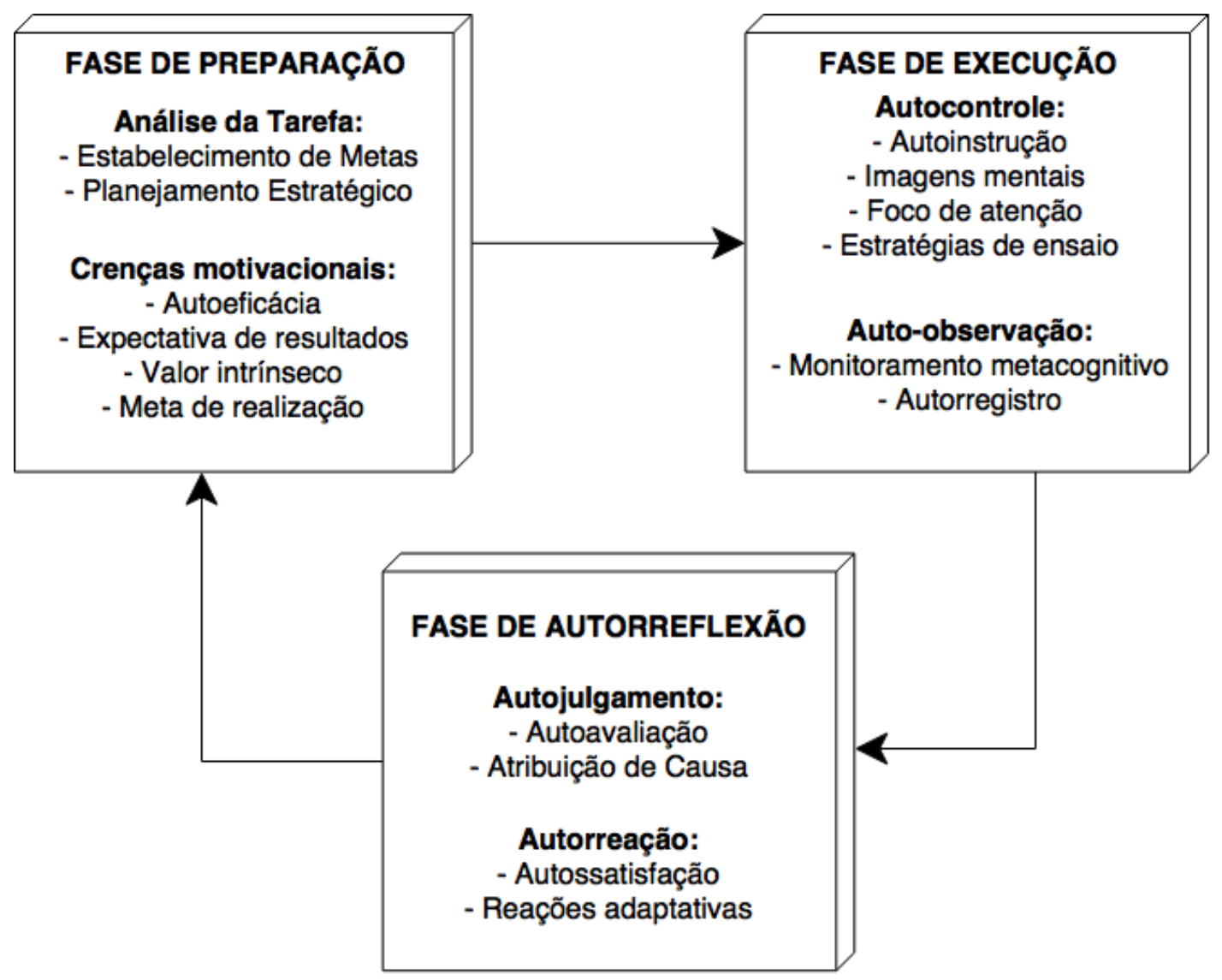

Fonte: Traduzido de Mcpherson e Zimmerman, 2011 p. 159. 
O processo é visto como cíclico pois os resultados da última etapa influenciam a fase de preparação e, consequentemente, todo o processo. É importante ressaltar que isto não ocorre de forma mecânica e linear: as diferentes etapas e subprocessos são relacionadas entre si, e esta divisão serve apenas para compreensão e estudo desse mecanismo. A autorregulação é um constructo e seu funcionamento não pode ser observado diretamente, apenas através do comportamento ou de inferências, como explica Freire (2009, p. 81).

\subsection{Autorregulação no aprendizado musical}

A capacidade de autorregular-se é um recurso importante para o desenvolvimento do músico como mostram alguns autores (HALLAM, 2001; MCPHERSON; ZIMMERMAN, 2002, 2011). Há um grande potencial em pesquisar o ensino/aprendizado musical sob a perspectiva da autorregulação até porque aprender um instrumento requer tanto ou mais autorregulação quanto qualquer outra área (disciplinas acadêmicas, esportes, etc). 0 aprendizado musical pode ser muito difícil no início e, geralmente, o estudo de música é opcional, o que requer motivação e autonomia sobre quando, onde e o quê praticar.

Ainda que o estudante seja orientado por um professor, a prática é realizada individualmente e seu desempenho depende de como conduzirá seus estudos. Se esse aluno não desenvolveu uma postura autônoma, nem teve contato com estratégias de estudo adequadas, poderá ter dificuldades em continuar seu desenvolvimento após o período de formação, uma vez que o aprendizado do músico não encerra quando termina o ensino formal, mas segue ao logo de toda a vida.

Mcpherson e Zimmerman (2011) explicam que a autorregulação é um conjunto de processos de contexto específico que os estudantes se utilizam ao aprender. Esses processos podem afetar uma ou mais dentre 6 dimensões da autorregulação em música, que são: 1) Motivo, 2) Método, 3) Tempo, 4) Comportamento, 5) Ambiente físico e 6) Fatores social. A primeira delas, Motivo, diz respeito a aspectos motivacionais e crenças pessoais que afetam o engajamento no aprendizado, como a autoeficácia; Método está relacionado aos procedimentos utilizados na execução das tarefas, com as variadas estratégias de ensaio, estudo mental e autoinstrução; Tempo inclui a administração e 
organização do uso do tempo; Comportamento engloba a capacidade de perceber, avaliar e modificar sua performance, envolvendo metacognição, autoavaliação e autorreações orientadas pela motivação; Ambiente físico trata da escolha, organização do local de estudo, embora muitos estudantes não tenham muito opção de controle sobre isso (ex: geralmente o local do piano é fixo na casa); os Fatores sociais incluem a influência e relações com pais, professores e colegas como suporte e fonte de orientação.

Como seriam então as etapas da autorregulação em relação ao aprendizado musical?

A fase de preparação engloba o estabelecimento de metas e seleção de estratégias, o que significa escolher objetivos de curto/longo prazo, por exemplo, dividindo uma tarefa complexa em etapas menores (e.g. desenvolver a técnica do tremolo para usar em repertório que exige isto) e selecionar estratégias adequadas para atingir este resultado. Conforme a habilidade se desenvolve, as metas e estratégias precisam ser revisadas e adequadas.

Na fase de execução, os processos de autocontrole ajudam os músicos a focar no que estão fazendo durante a realização das tarefas, através de autoinstrução (através de verbalizações para guiar a atividade, e.g. "Agora vou trabalhar o legato nessa frase"; “Cuidado para não acelerar esse trecho"), uso de imagens mentais, foco da atenção e estratégias de ensaio (tocar com metrônomo, estudar mãos separadas, repetir trechos ou seções da música, etc). Os processos de auto-observação podem incluir, por exemplo, o uso de gravações ou mesmo anotações sobre o trabalho e o progresso ao longo dos estudos. Além disso, os músicos podem usar a autoexperimentação para testar e observar a aplicação de novas ideias ou soluções em determinado repertório que já toque.

Na fase de autorreflexão ocorrem os processos relacionados a autoavaliação. 0 estudante de música que se autorregula tem boa noção para avaliar a si mesmo em relação a um parâmetro ou aos seus colegas. Além disso atribui o resultado a causas que são tangíveis e passíveis de melhora através do esforço. Já aqueles que atribuem falhas/sucessos a causas não modificáveis, como habilidade/talento (e.g. "Não sou muito bom nisso..."), estão mais suscetíveis a experimentar a frustração e desmotivação, além de apresentar maior dificuldade em se desenvolver. A satisfação positiva ou negativa com relação aos resultados influencia o engajamento do estudante na atividade, o que 
pode levar a reações adaptativas, tal como procurar outras estratégias para atingir as metas, ou defensivas, como evitar estudar, trocar de tarefa. Essa etapa influencia diretamente a fase de preparação, já que satisfação positiva pode reforçar a percepção de autoeficácia do estudante e estimular a procura por repertório mais desafiante, por exemplo.

A autorregulação não é uma característica fixa e a capacidade de controlar uma habilidade se desenvolve durante a formação, ou seja, o aperfeiçoamento desse mecanismo se dá de forma gradual ao longo do aprendizado. Mcpherson e Zimmerman (2011) explicam que o desenvolvimento da autorregulação tem origens sociais, ou seja, há maior dependência de apoio social no início do processo, que é gradativamente reduzido conforme a expertise se desenvolve. Esse processo se dá em 4 etapas: 1) Observação: ter referência de um modelo proficiente; 2) Emulação: imitação sob supervisão; 3) Autocontrole: capacidade de executar dentro de condições estruturadas; 4) Autorregulação: uso adaptável da habilidade em diferentes situações. Dessa forma, um iniciante aprenderia melhor quando exposto a modelos sociais, ensino eficaz, tarefas estruturadas e estímulo adequado.

Transportando para o âmbito musical pode-se exemplificar com o aprendizado de uma técnica nova (e.g. o arpejo ou o tremolo no violão). A observação de um modelo proficiente pode se dar com o professor, situação em que o aluno observa, ouve e compreende. A emulação ocorrerá em aulas, até que o aluno consiga executar a técnica em exercícios, estudos ou repertório didático, por exemplo. Por fim, a capacidade de autorregular essa habilidade ocorre quando o estudante consegue executar o que aprendeu com liberdade adaptando às exigências de cada situação (diferentes velocidades, dinâmicas, fraseado, etc).

Apesar da relevância da autorregulação para o desenvolvimento musical, há evidências de que procedimentos como o planejamento e a reflexão não são hábitos comuns dos estudantes (JORGENSEN, 2004, p. 99). Além disso, nem sempre eles usam estratégias adequadas, mesmo aqueles em conservatórios superiores de ensino (AUSTIN; BERG, 2006 ${ }^{10}$; MIKSZA, 2006 ${ }^{11}$ apud HALLAM; BAUTISTA, 2012, p. 672;

10 AUSTIN J. R.; BERG M. H. Exploring music practice among sixth-grade band and orchestra students. Psychology of Music, $n^{\circ}$ 34, 2006, p. 535-558.

11 MIKSZA, P. Relationships among Impulsiveness, Locus of Control, Sex and Music Practice. Journal of Research in Music Education, vol. 54, n 4, 2006, p. 308-323. 
NIELSEN, 1999) e muitos apresentam dificuldades em planejar seu estudo ou aplicar diferentes estratégias (CAVALCANTI, 2009).

Isso pode ocorrer por diversos motivos. Um dos mais importantes é a maneira como o assunto é abordado pelos professores, ou seja, de que modo é feito a transmissão desse conhecimento. Leon-Guerrero (2008, p. 103) comenta que o ensino de música ainda é muito pautado pelo resultado e não pelo processo, de forma que se fornecem modelos do que os estudantes devem atingir na performance, mas nem sempre estes são orientados adequadamente sobre como alcançar determinado nível. É fundamental, portanto, que os estudantes consigam construir habilidades de aprendizes autônomos e que os professores reflitam sobre como estimular os alunos a se engajarem no processo de aprendizado.

Os processos autorreguladores, como estabelecimento de metas, uso de estratégias e autoavaliação podem ser aprendidos através de instrução ou modelagem, tendo como referência pais, professores, coaches ou colegas, e esse aprendizado pode impactar positivamente os resultados obtidos pelos estudantes (ZIMMERMAN, 2002, p. 6). Algumas pesquisas recentes dão suporte a ideia de que é possível ensinar e aprender estratégias (BARRY, 1992; NIELSEN, 1999; MIKSZA, 2013; HATFIELD; LEMYRE, 2016). Miksza (2013), por exemplo, realizou um estudo experimental em que estudantes de sopro no ensino superior foram instruídos sobre como estudar, incluindo estratégias de ensaio e estratégias autorreguladoras, como organização, administração da concentração, planejamento, monitoramento, reflexão. Apesar das limitações do estudo quanto a generalização ou estabelecimento de relações causais, os participantes do grupo experimental demonstraram maior desempenho na performance, utilizaram melhor o tempo e as estratégias aprendidas, além de praticarem mais os aspectos interpretativos, o que reforça a importância e impacto da autorregulação na eficiência do aprendizado.

Há pesquisas evidenciando também uma estreita relação entre a estrutura da aula e como aluno estuda em casa, principalmente nos níveis mais iniciantes. Se a aula combinar tarefas específicas no trabalho com repertório, com exercícios de suporte e instruções claras sobre como praticar, no estudo individual o aluno tende reproduzir a 
mesma abordagem (KOOPMAN et al., $2007^{12}$ e BARRY, $2007^{13}$ apud LEHMAN; JORGENSEN, 2012, p. 686). Além disso, fornecendo referências de como organizar o estudo, estabelecer objetivos e registrar o que tem feito, o professor pode incentivar os alunos ao planejamento e à reflexão.

Hallam e Bautista (2012, p. 673), comentam que mudanças na pedagogia do instrumento, como o professor enfatizar em aula a maneira de estudar e usar estratégias, pode ser benéfico para o aprendizado, desde que realizado por longo período. Além disso o professor pode avaliar se o aluno está usando esse conhecimento, ao fornecer obras novas e pedindo que identifique trechos difíceis e que explique como praticará. 0 uso de gravações em aula também pode ser uma forma de estimular a autoavaliação e a reflexão sobre o estudo. A motivação é maior quando o aluno assume papel ativo no aprendizado e aulas poderiam ser elaboradas de modo a criar mais oportunidades para os alunos se engajarem na atividade autorregulada.

Os professores devem estar atentos também à individualidade dos alunos, já que nem sempre uma estratégia de estudo vai funcionar para todos. Muitos problemas de hábitos de estudo estão também relacionados a aspectos motivacionais e é importante conversar abertamente sobre isso para ajudar a encontrar soluções.

Algumas orientações gerais emergem da literatura científica sobre o assunto, direcionadas não apenas aos professores, mas também aos estudantes (BARRY; HALLAM, 2002, p. 160; LEHMANN; JORGENSEN, 2012, p. 687). Por exemplo:

- Buscar um repertório próprio de estratégias eficazes e flexíveis para diferentes tarefas e situações;

- Abordar a prática de maneira consciente e planejada, sendo bastante específico sobre os objetivos da sessão de estudos;

- Usar um diário para registrar planejamento, problemas encontrados, soluções, de forma que possa acompanhar progresso do trabalho, estratégias usadas e ideias;

12 KOOPMAN, C; SMIT, N.; de VUGT, A.; DEENER, P.; \& den OUDEN, J. Focus on practice-relationships between lessons on the primary instrument and individual practice in conservatoire education. Music Education Research, 9 (3), 2007, p. 373-397.

13 BARRY, N. H. A qualitative study on applied music lessons and subsequent student practice sessions. Contributions to Music Education, 34, 2007, p. 51-65. 
- Desenvolver a capacidade de autoavaliação, gravando a si mesmo e ouvindo criticamente, com ajuda de colegas ou do professor;

- Realizar atividades que vão além da prática motora, como ouvir música, analisar, solfejar, ler, planejar e refletir sobre o estudo.

Ao se engajar dessa maneira no estudo individual, o estudante certamente desenvolverá autonomia, no sentido de compreender seus processos de aprendizados, formar um repertório de estratégias pessoais, ampliar a capacidade de observação crítica e a disposição na busca de soluções para os problemas encontrados.

Os trabalhos com propostas de intervenção têm dado suporte a ideia de que esta abordagem pode ter um impacto positivo no aprendizado musical e várias discussões sobre o ensino são levantadas pelos autores. Ainda assim, a pesquisa sobre como ensinar estratégias de aprendizagem para alunos de diferentes níveis ainda carece de investigações, principalmente na prática musical. 


\section{ESTRATÉGIAS DE APRENDIZADO NA LITERATURA MUSICAL}

A partir de uma busca na literatura escrita por autores músicos foram selecionadas as referências principais para o trabalho. Não será feito aqui um levantamento histórico e discussão sobre todos os métodos e livros didáticos voltados à prática instrumental, o trabalho volta-se principalmente àqueles que trazem informações a respeito do estudo individual, com ênfase no violão.

De forma geral, os primeiros métodos de prática instrumental traziam noções gerais sobre o uso do instrumento, informações sobre teoria musical, exercícios, estudos e pequenas peças. Nesse material é raro encontrar orientações sobre o processo de estudo ou mesmo estratégias de aprendizagem, provavelmente porque esse conteúdo era apresentado nas aulas ou porque a preocupação principal dos métodos era possibilitar a execução instrumental básica, a compreensão musical e apresentar o estilo vigente através do repertório. Isso se nota, por exemplo, ao observar que todo o conteúdo, mesmo os exercícios, estão sempre vinculados a uma ideia musical e não tratam apenas do aspecto mecânico isoladamente. Apesar disso, é possível ver alguns breves apontamentos sobre o processo de estudo já em métodos do século XVIII, como em Carl Philipp Emanuel Bach, Leopold Mozart, Johann Joachim Quantz. É comum também haver certa disparidade entre as informações apresentadas por esses autores, como aponta Reid (2002, p. 103), ao citar, por exemplo, a diferença entre a quantidade de horas de estudo recomendada por alguns deles.

É importante ter em mente que estes trabalhos foram produzidos em contextos diferentes, representam um pensamento de suas respectivas épocas, com outras características de repertório, outros instrumentos, diferentes demandas técnicas e uma visão sobre o aprendizado musical que pode estar desatualizada com relação a aspectos de fisiologia, aprendizado neuromotor, memorização, dentre outros. É possível que várias informações colocadas como certas para o aprendizado já tenham sido questionadas pelos músicos da atualidade e também revisadas pela pesquisa empírica.

Richerme (1997, p. 17) discute essas incoerências ao rever a abordagem dos diversos teóricos da técnica pianística desde o século XIX. Testemunhos sobre a performance de grandes pianistas como Liszt e Chopin, cujas técnicas foram desenvolvidas principalmente através da experimentação prática, descrevem aspectos 
importantes da execução desses músicos que jamais eram mencionados pelos teóricos nos livros de técnica da época (tal como o uso da movimentação ou peso natural do braço). Em alguns casos, se propunha como solução para todos os problemas técnicos a repetição massiva de exercícios. 0 autor mostra que há inconsistências não apenas nos livros do período pré-científico dos teóricos de piano (considerado pelos pesquisadores o período anterior à década de 1880), mas também nos trabalhos do século XX, que apesar dos avanços propostos pela investigação científica, ainda incluíam erros metodológicos de pesquisa.

É importante questionar também se essas informações das pesquisas sobre a prática musical têm chegado na pedagogia do instrumento, visto que muitos professores não se atualizam ou reveem suas práticas, ou que vários músicos ainda se baseiam apenas na sua experiência, em generalizações ou informações superficiais a respeito do que funciona no aprendizado. A prática artística conta sim com a experimentação, a busca de soluções diferentes, o estabelecimento de relações inusitadas e uma grande dose de individualidade. No entanto, não há dúvidas de que o diálogo entre a visão prática e analítica (científica) pode otimizar o ensino/aprendizado, diminuir o uso inadequado da tentativa/erro, prevenindo a transmissão de informações superficiais e equivocadas sobre a prática musical de forma a evitar lesões e frustrações.

O piano conta com um grande número de trabalhos teóricos desde o século XIX e mais amplamente no século XX, alguns já com uma abordagem científica (e.g. Arnold Schultz, 1936; George Kochevitsky, $1967^{14}$ ) e preocupados também com o processo aprendizado. Apesar de algumas divergências e inconsistências (como explicam Richerme, 1997 e Barros, 2008) vários destes trabalhos refletem as práticas de diversos pianistas como performers e professores. Alguns tornaram-se importantes referências, como o método de Leimer-Gieseking (1932/1938) cujo eixo principal de seu livro é a prática mental no estudo instrumento, através do recurso da visualização no aprendizado de repertório antes da execução física.

Há também métodos voltados ao violino, como os de Carl Flesch, Ivan Galamian e Robert Gerle, que fornecem orientações sobre o estudo individual. Flesch (1939, p. 157), por exemplo, afirma que a habilidade de pensar logicamente no estudo pode poupar

14 The Riddle of the Pianist's Finger (Arnold Schultz, 1936), Art of Piano Playing (George Kochevitsky, 1967) 
tempo e esforço. Seguindo esse raciocínio, o autor traz informações específicas para a abordagem de obras novas, resolução de problemas e ainda sugere hábitos que devem fazer parte da rotina de estudos do violinista, dentro do que ele chama de higiene do estudo. Essas ideias estão presentes também em Galamian (1962, p. 93), o qual atesta que a prática individual deve ser considerada como uma continuação da aula, onde o estudante deve agir como seu próprio professor, definindo e supervisionando seu trabalho - visão esta partilhada por alguns violonistas, assunto discutido adiante.

\subsection{A literatura voltada ao violão}

No século XIX, o violão ainda passava por transformações na sua construção e na consolidação da técnica de execução. Os principais métodos do período incluíam basicamente informações gerais sobre o instrumento, exercícios e estudos práticos, além algumas noções básicas de teoria musical. Para citar um exemplo pode-se observar o Método Completo per Chitarra Op.27 (1810) de Ferdinando Carulli. Este é divido em 3 partes: a primeira explica o manuseio do instrumento e apresenta aspectos básicos da execução, tal como o uso dos dedos, exercícios iniciais, escalas, arpejos e acordes. (Carulli apresenta uma tonalidade, sua escala no instrumento, um exercício e um pequeno estudo dentro do estilo clássico, geralmente uma miniatura em forma binária, pequenas valsas ou rondós); na segunda parte expõe elementos de articulação, ornamentação, intervalos e harmônicos com exercícios em diferentes posições do instrumento; na terceira parte há peças de maior complexidade e uma série de duos para professor e aluno. Apesar de algumas pequenas diferenças, este era um formato comum entre os métodos desse período.

Alguns desses métodos são mais simples, como o Studio per Chitarra op.1 (1812) de Mauro Giuliani, que é basicamente um método prático, contendo uma série de exercícios de arpejo (as conhecidas 120 fórmulas de arpejos, reproduzidas em muitos métodos atuais), estudos de intervalos, ornamentos e algumas pequenas peças. Outros, ainda incluem elementos de teoria musical, tal como nos métodos Matteo Carcassi (1836) e Dionísio Aguado (Escuela de Guitarra, 1825 e Nuevo método para guitarra, 1843). Este último fala inclusive sobre o uso harmonia e formação de acordes no instrumento, além de outros tópicos como a produção do som com ou sem unhas, 
vibrato (prolongación del sonido) e sobre o uso da dinâmica a favor da expressão musical.

Dentre os métodos do século XIX, o Método para Guitarra (1830) de Fernando Sor é uma importante referência na literatura violonística no qual o autor propõe uma abordagem racional da prática ao instrumento. Embora não fale exatamente sobre em estratégias de aprendizado, este método não é apenas um livro de exercícios e estudos técnicos, mas sim um tratado sobre como tocar o instrumento, apresentando preceitos básicos para a boa execução, em função do conteúdo musical e artístico. 0 seu método incentiva a observação e a reflexão na prática musical, uma postura que se alinha com as ideias do Iluminismo, referência na elaboração de seu trabalho, como explica Camargo em sua tradução comentada do método (2005, p. xvii).

Outra referência, já no século XX, é o livro Escuela Razonada de la Guitarra (1933) de Emílio Pujol, baseado nos princípios de Francisco Tárrega, do quem foi um dos principais discípulos. Neste livro, como o título já propõe, Pujol apresenta uma abordagem fundamentada e lógica da prática do violão, oferece algumas orientações gerais sobre a maneira de estudar os exercícios, estudos e obras, alertando para alguns importantes aspectos do estudo, por exemplo:

Meu primeiro conselho ao iniciante é que, antes de tudo, aprenda a estudar porque nisto consiste o segredo de uma boa técnica. A qualidade do estudo importa mais do que a quantidade; a assiduidade mais do que a insistência; a reflexão, mais do que a obstinação. (...) De pouco serve estudar de modo automático crendo que a quantidade de horas de estudo resolverá tudo. A intensidade da atenção no trabalho é o principal. $\left(1933\right.$, p. 18) ${ }^{15}$

Nesse sentido, Pujol se alinha com o pensamento de Sor, ao promover uma postura reflexiva no estudo individual. No entanto, embora o conteúdo tenha de fato grande valor para o aprendizado, os conselhos para o processo de estudo nem sempre são fornecidos na forma de procedimentos claros ou ações específicas ${ }^{16}$ (e.g. Sor diz:

15 Tradução do autor: Mi primer consejo al principiante ha de ser, ante todo, que aprenda a estudiar porque en ello consiste el secreto de una buena técnica. La calidad del estudio importa más que la cantidad; la asiduidad, mas que la insistencia; la reflexión, mas que la obstinación. (...) De poco sirve estudiar como um autómata creyendo que la cantidad de horas de estudio lo resuleve todo. La intensidad de atención en el trabajo es lo principal.

16 Isto não significa que esses ensinamentos tenham menor importância para o violonista. No entanto, como este trabalho adota uma abordagem pragmática do estudo individual, no sentido de buscar e fornecer procedimentos práticos, estas referências não serão utilizadas diretamente. 
"Dar muito valor ao raciocínio e nenhum à rotina"; Pujol afirma: "Corrección es sinónimo de facilidad").

Mais adiante há os trabalhos do violonista e pedagogo Abel Carlevaro, um importante marco na história do instrumento. Carlevaro trouxe outra visão na abordagem do aprendizado do violão, sistematizando em Escuela de la Guitarra (1979) diversos aspectos técnicos e mecânicos para uma boa execução ao instrumento, enfatizando a observação, o uso adequado do corpo, das mãos e o raciocínio como elemento fundamental na prevenção de problemas e na busca de soluções. Esta postura frente ao aprendizado é presente em todos os seus livros, como os 4 Cuadernos de Técnica (1966-1979) e a série Guitar Masterclass (1985-1989), onde aplica os conceitos discutidos em Escuela de Guitarra na abordagem de algumas peças do repertório do violão. Nesta última série, Carlevaro oferece diversas soluções para algumas das principais obras do violão (Fernando Sor, Villa-Lobos e Bach) abordando aspectos interpretativos e da mecânica instrumental necessários à execução. 0 material é voltado exclusivamente para abordagem desse repertório, mas os procedimentos apresentados, como análise prévia do material, estabelecimento de metas para o estudo e elaboração de exercícios para solucionar trechos problemáticos são uma excelente referência de como estudar, de forma que este raciocínio pode ser transferido para qualquer outro repertório.

Eduardo Fernandez, violonista que foi aluno de Carlevaro, segue de forma semelhante a abordagem racional da prática instrumental em seu livro Técnica, Mecanismo e Aprendizaje (2000), cujo objetivo é "propor um tipo de trabalho que desperte a inteligência e as faculdades críticas do estudante" (p.10), estimulando o uso mais consciente da mecânica instrumental na resolução de problemas técnicos dentro do repertório ${ }^{17}$. Para isso, analisa e propõe exercícios sobre diversos elementos mecânicos e exemplifica sua abordagem ao mostrar como trabalhar as dificuldades de uma passagem em alguns excertos do repertório do violão. Uma visão importante que Fernandez apresenta é que a aprendizagem desses aspectos passa pela subjetividade do estudante e, portanto, para que deixe de ser um estudante e se torne um professor (de si

17 Para discutir o assunto, Fernandez define esses conceitos em seu livro, sendo: o Mecanismo, o conjunto de reflexos adquiridos que permitem tocar o instrumento; a Técnica, os procedimentos a seguir a fim de dominar uma passagem ou uma dificuldade; e a Aprendizagem, o processo de aquisição desses reflexos (mecânica) ou do domínio de uma passagem/dificuldade (técnica). 
mesmo) é necessário desenvolver o domínio sobre suas ações, ou seja, desenvolver a autonomia no aprendizado.

Nas últimas décadas alguns autores têm elaborado métodos com uma abordagem mais pragmática, como é o caso de Scott Tennant em Pumping Nylon (1995), que propõe exercícios práticos para desenvolver diversos elementos da técnica instrumental e resolver problemas mecânicos. Interessante também é sua proposta de rotina diária de estudos, sugerindo uma organização básica de trabalho técnico. Além disso, traz algumas obras do repertório, com orientações prévias para a leitura que incluem desde orientações interpretativas até soluções técnicas. Esse direcionamento do trabalho nessas peças funcionam também como metas que devem guiar o estudo, ponto fundamental para o estudante.

Um pouco dessa abordagem está presente também no livro Khitarologus (1997) de Ricardo Iznaola, que propõe exercícios diversos para trabalhar os mecanismos básicos da técnica instrumental. Iznaola fornece orientações inciais para a prática desse material, apresenta objetivos claros para cada exercício e ainda sugere um modelo organização semanal para distribuir o trabalho de forma equilibrada, como uma referência para a rotina de estudos.

Há também informações sobre técnica, interpretação e hábitos de estudo do violonista em livros como os de Antonio Contreras (que organizou La técnica de David Russell en 165 consejos, 1998) ou Martha Masters (Reaching the next level, 2010). 0 violonista Anthony Glise (Classical Guitar Pedagogy, 1997), por exemplo, apesar de voltar-se principalmente ao professor, inclui importantes orientações sobre a prática do violonista e reflexões sobre o estudo individual. Dentre esses diversos materiais voltados ao estudo do violão há alguns autores que não falam diretamente sobre técnica ou exercícios, mas abordam principalmente o processo de estudo individual. Dois exemplos são os livros On Practicing (2000) de Ricardo Iznaola, e The Art and Technique of Practice (1992), de Richard Provost. Ambos tratam de assuntos como planejamento, organização do estudo, estabelecimento de metas e resolução de problemas, enfatizando uma postura ativa no aprendizado.

Outro autor que trata também deste conteúdo é Lee F. Ryan em The Natural Guitar (1991). Com uma visão holística da prática ao instrumento, o autor propõe estratégias que visam uma maior consciência em vários aspectos do estudo, com 
referência à prática de importantes músicos, métodos de outros violonistas e conceitos de filosofias orientais. Ryan apresenta estratégias de estudo na abordagem de obras novas, administração da atenção no estudo, uso da visualização, preparo para a performance e consciência corporal.

Vale destacar que uma das primeiras referências que fez parte de minha formação com relação à organização do estudo foi durante a graduação, com as tabelas de técnica e de estudos que o violonista e Prof. Dr. Edelton Gloeden utiliza com seus alunos. A proposta é promover o aprendizado progressivo e equilibrado de diferentes aspectos da técnica e do repertório, servindo também como uma referência de estudo semanal.

Os diversos autores violonistas citados são de grande importância para a desenvolvimento da prática instrumental e referências indispensáveis para o estudante. Vários deles, direta ou indiretamente, trazem estratégias de estudo, como Carlevaro, Fernandez e Tennant. No entanto, como base para este trabalho, as principais referências de autores violonistas serão: Iznaola, Provost e Ryan, já que falam de maneira mais explícita do processo de estudo, com sugestões específicas e procedimentos mais definidos sobre planejamento, organização, administração do tempo, concentração, preparo para performance e resolução de problemas.

Ainda na literatura musical, será relevante para este trabalho o livro de Gerald Klickstein, Musician's Way (2009). Este material tem a proposta de ser um guia para o estudo do músico, tratando de uma variedade de aspectos que vão desde a organização da rotina até sugestões para carreira. 0 autor não se prende a um instrumento específico e suas orientações são mais voltadas à tradição de música clássica ocidental. Tem como referência trabalhos de importantes autores da área musical, orientações de concertistas consagrados e alguns trabalhos da pesquisa empírica sobre aprendizado musical. 


\section{ORIENTAÇÕES PARA A ROTINA DE ESTUDO DO VIOLONISTA}

\subsection{Relacionando a autorregulação com as estratégias apresentadas pelos autores violonistas}

O autor Jorgensen (2004) discute as estratégias de estudo dentro de um modelo cíclico da autorregulação da aprendizagem em música (MCPHERSON; ZIMMERMAN, 2002; ZIMMERMAN 2000, 2002) e organiza esse conteúdo de acordo com as 3 fases do processo. Seguindo essa mesma ideia, esta seção do trabalho pretende relacionar as estratégias apresentadas pelos autores selecionados com as etapas da autorregulação da aprendizagem e os subprocessos envolvidos. Portanto, as informações fornecidas nessa literatura específica serão organizadas e discutidas tendo como referência o modelo de aprendizagem autorregulada de Zimmerman e pesquisas sobre o planejamento da execução instrumental.

Conforme discutido no capítulo 2, as etapas da autorregulação não ocorrem separadamente de modo claro: o processo é cíclico e pode ocorrer em vários momentos, seja, por exemplo, na observação macro do estudo semanal ou no exato momento em que se está estudando. Dessa maneira, ao longo do texto muitas informações presentes em uma etapa estarão ligadas às outras.

Ao relacionar as estratégias discutidas pelos violonistas ${ }^{18}$ com as etapas da autorregulação pretende-se fornecer caminhos para promover maior consciência e otimização da prática ao estimular a autonomia no estudo. É importante ressaltar, porém, que nem todas as informações e estratégias apresentadas pelos teóricos da prática instrumental foram analisadas em pesquisa experimental, o que será destacado ao longo do texto.

As estratégias levantadas aqui são voltadas principalmente ao violonista estudante em nível de formação superior (universidade, conservatório superior), que já teria condições de buscar maior autonomia no seu desenvolvimento. É difícil estabelecer o nível específico que isso representa, já que há grande disparidade entre as universidades e instituições nas diferentes regiões do país. Além disso, no Brasil há uma

18 Os autores escolhidos falam principalmente voltados a violonistas, embora aleguem em seus livros que muitas informações serviriam para qualquer instrumentista. 
grande deficiência no ensino básico de música (que é consequência também das amplas deficiências no ensino regular). 0 estudante violonista geralmente chega na graduação com lacunas em sua formação técnica e musical, visto que nem sempre passou por escolas bem estruturadas ou bons professores. Dessa forma, para deixar claro qual seria esse nível, pode-se pensar que seria um estudante com capacidade técnica para tocar estudos e repertório básico do violão clássico (Carcassi, Sor, Giuliani) e que já esteja formando uma consciência musical que lhe permita, por exemplo, analisar e compreender elementos estruturais básicos das músicas que toca. Muitas das estratégias aqui podem servir a alunos intermediários e até mesmo iniciantes, mas estes ainda devem contar, certamente, com a orientação de um professor, cuja experiência e feedback serão essenciais para o desenvolvimento da observação critica e do uso de diferentes estratégias no estudo individual.

\subsubsection{Estratégias na Fase de Preparação}

\subsubsection{Análise da Tarefa}

Os autores selecionados trazem várias informações para o planejamento e organização do estudo individual, e, de maneira geral, com um raciocínio muito próximo entre eles.

Iznaola (2000, p. 10) fala da importância de planejar o que e quando estudar, dentro de um planejamento semanal e diário. A rotina de trabalho deve incluir um material variado, com exercícios, estudos e repertório. Para a organização/estrutura do estudo, sugere uma divisão em 3 blocos: Construção, Interpretação e Performance. Essa divisão, proposta pelo violinista Ivan Galamian, procurar equilibrar a prática de modo a incluir treino técnico, trabalho de elementos expressivos nas músicas e preparo para a performance.

Klickstein (2009, p.6) propõe também uma divisão, na qual o estudo deve inclui 5 áreas: Repertório Novo, Desenvolvimento, Performance, Técnica e Musicalidade. Com essa proposta o estudo é organizado de acordo com o estágio em que se encontram as músicas. Além do trabalho técnico separado, o autor inclui a área "musicalidade" com atividades que costumam ser negligenciadas por estudantes e que trazem vários 
benefícios para a compreensão musical e criatividade, como a escuta atenta de músicas, leitura, percepção e improvisação. Um bom treinamento auditivo pode ajudar a monitorar o próprio estudo e cultivar uma variada gama de referências de outros intérpretes pode estimular o trabalho da expressividade e facilitar a aprendizagem. Essas são importantes atividades que permitem desenvolver a capacidade musical sem estar necessariamente trabalhando no instrumento.

Provost (1992, p. 8) comenta que planejar ajuda a priorizar o estudo, os objetivos e administrar o tempo. Contudo, alerta que a rigidez de estudo baseado em planejamento preestabelecido, ao mesmo tempo que pode servir muito bem a algumas pessoas, pode desestimular outras, já que as sessões de estudo seriam aparentemente todas previsíveis. Para isso, destaca que a sequência e a distribuição do estudo pode variar e que cada um deve buscar o formato que o estimule ao aprendizado.

Os autores não falam que essa divisão deve ser rigorosa, mas que deve funcionar como um guia para estruturar sua própria maneira de estudar. Conforme explicado no capítulo anterior, as estratégias não funcionam para todos de forma igual. Portanto é importante conhecer e explorar essas sugestões, ainda que com o suporte de um professor, para observar e reconhecer a maneira que funciona para si mesmo. Isso depende do desenvolvimento das habilidades metacognitivas, ou seja, o conhecimento sobre o processo do aprendizado, as características pessoais de trabalho, as necessidades da tarefa e como usar as estratégias adequadamente.

Sobre o trabalho técnico dentro da rotina de estudos, os autores salientam a que se deve dedicar um tempo do estudo exclusivamente para isso e que esse tempo deve ser compatível com seu nível técnico e objetivos (ou seja, quanto mais deficiente a parte técnica, maior prioridade a esse trabalho). Klickstein defende a regularidade desse trabalho, assim como estabelecer limites para evitar lesões musculares e recomenda o uso de recursos externos para se observar (espelho, gravação em vídeo). Iznaola é incisivo e afirma que a ideia de que se adquire técnica trabalhando apenas repertório é uma ilusão, já que ela depende também da boa forma física da parte mecânica. Defende o estudo de técnica isolado das músicas, ao menos até que se esteja em um estado avançado e com as etapas de formação bem consolidadas, estágio no qual se pode extrair pontos do repertório para o estudo técnico. 
A manutenção de repertório antigo é um ponto importante no planejamento, embora seja negligenciado por muitos. Jorgensen (2004, p. 88) cita resultados de uma pesquisa $^{19}$ que realizou na qual observou que os estudantes não tinham uma estratégia para rever sistematicamente o repertório antigo, se atendo basicamente a exercícios técnicos e repertório novo. Talvez isso reflita uma característica de alunos no ensino superior, que têm uma demanda de trabalho com várias disciplinas e precisam sempre aprender e trocar o repertório. Klickstein (2009, p. 73) fala um pouco sobre esse aspecto e recomenda revisar detalhadamente as músicas, trabalhando novamente passagens problemáticas e a interpretação como se estivesse estudando a obra pela primeira vez. Como geralmente há várias músicas para revisar é interessante criar uma rotatividade no planejamento e incluir esse repertório antigo em recitais.

É comum iniciar o estudo com algum exercício (com escalas, arpejos, etc) e muitos o fazem como uma forma de aquecimento. Contudo, o aquecimento não precisa ser necessariamente a prática de exercícios técnico-mecânicos. Todos os autores escolhidos sugerem procedimentos para iniciar o estudo, em geral com a proposta de preparação mental e física para a atividade. Dentre eles, Klickstein é o único ${ }^{20}$ que cita especificamente o termo aquecimento (warm-up) e destaca seu papel como atividade preparatória para o estudo, incluindo relaxamento e preparação muscular para o trabalho, de forma a facilitar a atividade e tornar os músculos menos suscetíveis a lesões. Para isso, sugere que se faça algum exercício de respiração e movimentos leves antes de tocar, revise as metas, inicie lentamente tocando algo fácil e de baixa exigência técnica (exercícios, peças ou improvisos), gastando no máximo de 10 a 15 minutos. Ressalta ainda que não há aquecimento ideal, depende das suas necessidades e recomenda que se varie essa atividade.

Apesar de não falar diretamente sobre isso, no preparo para o estudo Ryan recomenda desenvolver a consciência/vigilância (awareness) para ter clara noção do que está fazendo durante a prática, dos problemas que ocorrem e de como lidar com eles. Explica que ao acalmar a mente e o corpo é possível concentrar-se na atividade e aguçar as percepções (auditiva, visual, táctil, intuitiva), algo que pode ser realizado através de técnicas de relaxamento, respiração, meditação, Yôga, exercícios leves, dentre

19 Jorgensen, H. Planlegges oving? [Is Practice Planned?]. Oslo: Norwegian Academy of Music, 1998.

20 Tennant (1998) é outro autor que também fala em rotinas de aquecimento. 
outras sugestões (1991, p. 36). Provost sugere igualmente exercícios de respiração e relaxamento progressivo para acalmar qualquer agitação que possa estar acumulada durante o dia (1992, p.15). Alerta ainda para procurar identificar quando há fadiga e cansaço, que atrapalham a produtividade e cuja solução é descansar. Essas recomendações sobre relaxamento e preparo mental para a atividade são fundamentais para a concentração no estudo. 0 trabalho sem foco definido trará poucos resultados e exigirá maior custo de tempo e energia.

Klickstein ressalta também a necessidade organizar o espaço em que se estuda, dentro do possível com iluminação e temperatura adequadas, certo grau de silêncio e privacidade, com um mínimo de distrações e munido do material que julgar necessário (e.g. estante, metrônomo, afinador, caderno de anotações, lápis, gravador). Não precisa ser a melhor sala possível de estudos, mas que tenha o suficiente para facilitar o trabalho. Mcpherson e Zimmerman (2011) consideram o ambiente de estudo um dos elementos que afetam a autorregulação e a eficiência do aprendizado, apesar de ainda ser necessário aprofundar a pesquisa sobre este assunto na prática musical.

Com relação ao tempo de estudo todos os autores destacam que a regularidade, a prática distribuída, o trabalho em sessões curtas de estudo, a realização de intervalos entre as sessões são fundamentais. Iznaola recomenda distribuir as tarefas durante a semana e ao longo do dia. Dessa forma não há sobrecarga mental e física em nenhum dia ou sessão de estudos, ao mesmo tempo que se pode trabalhar de forma equilibrada tudo o que planejou. $\mathrm{O}$ autor considera ainda incluir um dia de descanso semanal, ainda que se possa tocar, mas sem o compromisso de estudar.

Provost salienta que a regularidade ajuda a criar o hábito de trabalhar, mesmo quando a motivação/disposição não é totalmente propícia (1992, p.11). Ryan partilha dessa ideia e comenta que se por algum motivo não for possível praticar em um dia, pode-se estudar ao menos por 15 minutos e para trabalhar algum aspecto e manter o hábito de estudar (1991, p.171).

Sobre a duração do estudo, de maneira geral, a recomendação é de que as sessões de estudo não passem de 1 hora de duração com intervalos de 10 a 15 minutos entre elas. Iznaola comenta que para estudantes em nível superior uma média de 2 a 3 horas pode ser suficiente, divididas em 3 sessões durante o dia. Alerta que mais do 5 ou 6 horas de estudo traria poucos resultados. Ryan, de maneira semelhante, afirma que nem 
o iniciante e tampouco o concertista devem praticar em demasia (over-practice), apesar de considerar que a duração total de prática diária depende de cada um. 0 autor destaca que a prática não deve ser realizada por longos períodos e que o aprendizado pode ser melhor se o estudo for divido em sessões curtas e concentradas de trabalho ${ }^{21}$. Sobre isso, comenta que muitas vezes o tempo de estudo que um concertista atribulado terá serão momentos fragmentados entre viagens e outras atividades.

Klickstein enfatiza a importância dos intervalos de descanso no estudo que servem tanto para corpo quanto para a mente e descreve 3 tipos de intervalo: ativo, recreativo e restaurador (2009, p.75). No intervalo ativo, você descansa os músculos que usa para tocar mas continua trabalhando de outra forma (e.g. solfejando, anotando informações da partitura). No recreativo, você deixa o ambiente de estudo e distrai também a mente do trabalho (e.g. andando, tomando café). Por fim, no restaurador, você pausa o trabalho e simplesmente descansa ou realiza algo para revitalizar o corpo e a mente (e.g. alongamentos, movimentos leves). 0 autor destaca ainda um ponto importante para o planejamento: ao agendar o tempo dedicado ao estudo, deve-se incluir o tempo dos intervalos e do aquecimento. Sobre esse aspecto, é possível encontrar pesquisas mostrando os efeitos positivos do descanso e do sono sobre a prática musical e para a autorregulação da aprendizagem, influenciando a concentração, a consolidação de habilidades motoras e a precisão na performance, como mostra Miksza (2013, p. 3).

O tempo de uma sessão de estudo deve levar em conta a tarefa em questão e a energia necessária para o trabalho, com explicam Chaffin e Lemieux (2004, p. 25). Mas de forma geral, sessões curtas, menores que uma hora, separadas por intervalos de descanso ajudam a administrar a atenção no aprendizado é a recomendação entre as pesquisas.

A quantidade de tempo de estudo, é uma questão controversa na literatura e na pesquisa empírica. Este tempo pode variar de acordo com características individuais e instrumentais, como aponta Jorgensen (2004, p. 90). É possível ver que os autores não defendem nenhuma quantidade fixa de tempo de estudo, apenas apresentam uma

21 Essa visão é partilhada por vários outros músicos teóricos da prática instrumental, como Giseseking-Leimer (1932/1938), quando diz que o estudo ao longo 6 a 7 horas é geralmente feito sem concentração e prejudicial a saúde. Ou Carl Flesch(1939), que recomenda a prática frequente e em pequenas doses (Non multa, sed multum. Do latim: não muitas coisas, mas algo importante). 
estimativa que seria suficiente para realizar um bom progresso no aprendizado do instrumento.

Quando o estudante está em transição para um nível mais avançado, que é o caso do aluno na graduação, é fundamental que organize de alguma maneira o conteúdo que está desenvolvendo. 0 trabalho com repertório será mais exigente, a carga de trabalho aumenta e sendo crucial distribuir as tarefas adequadamente, controlar o tempo, o esforço físico e o mental. Essas divisões propostas pelos autores são referências que podem ajudar a manter o controle do que se está estudando e evitar que sejam negligenciados importantes aspectos do desenvolvimento musical.

Os autores Ryan, Provost e Klickstein falam da necessidade de se estabelecer metas claras para o estudo, pensando a longo, médio e curto prazo. Estes autores ressaltam também a importância de não tornar o planejamento algo rígido e inflexível, mas também evitar grandes alterações, já que constantes concessões podem levar à procrastinação. Muitos desvios podem significar falta de disciplina ou necessidade de rever o plano e os objetivos. Um ponto que Provost salienta é que as metas devem estar equilibradas às possibilidades, escolhendo a princípio poucos objetivos na semana (2 ou 3), e ir renovando conforme os alcança. Estabelecer diversas metas pode levar à confusão para o trabalho e à frustração de não conseguir realizá-las; por outro lado, poucas metas tendem a limitar o desenvolvimento, causar tédio e desmotivar.

Mais uma vez é evidente na fala dos autores a influência das características individuais na prática e a importância de conhecer seus próprios limites e potencialidades, o que se relaciona à capacidade metacognitiva. A flexibilidade no planejamento e administração das metas depende da eficiência em autorregular-se, já que exige observação e reflexão sobre processo de estudo para rever o planejamento, repensando as metas estabelecidas e as estratégias selecionadas. Uma constante falha em atingir objetivos que foram estabelecidos sem real diagnóstico das causas, conhecimento das próprias possibilidades e sem revisão do planejamento provocaria frustração e diminuiria a motivação para seguir engajado no aprendizado, dificultando ainda mais o processo.

Para Chaffin e Lemiux (2004, p. 26), o estabelecimento de metas é uma das características fundamentais para o desenvolvimento da excelência musical. Ter metas no estudo promove orientação, motivação, esforço, direciona a atenção e melhora o 
aprendizado (ver Connolly e Williamon, 2004, p. 240). Além disso, estabelecer objetivos específicos e estimulantes é mais produtivo do que simplesmente pensar em fazer "o seu melhor" ou trabalhar sem metas. Jorgensen (2004, p. 89) cita que as metas tendem a se encaixar em dois aspectos: metas para a qualidade técnica da performance e metas para a qualidade expressiva da performance.

Sobre o trabalho de aspectos expressivos, há músicos que trabalham a partir de um plano preconcebido da performance; outros que desenvolvem a ideia ao longo do estudo e há aqueles combinam ambas abordagens (HALLAM, 1997²2). Outro procedimento comum é também resolver as dificuldades técnicas primeiro para depois trabalhar na concepção da performance (NIELSEN, 2001). Não há ainda pesquisa indicando se um método é mais eficiente do que outro e seu resultado depende de características individuais e do tipo de música estudada.

Klickstein e Provost recomendam registrar o planejamento e o trabalho realizado usando alguma forma de diário ou relatório, fornecendo em seus livros modelos e exemplos de como proceder. Este registro pode servir de suporte para o macro e microgerenciamento do estudo, incluindo as metas estabelecidas, a organização semanal, as tarefas diárias e os objetivos para cada tarefa da sessão de estudos. Permite também anotar o que foi realizado para revisão e avaliação posterior do trabalho. Esta simples ferramenta pode ser um grande aliado para a eficiência do estudo e para aperfeiçoar o aprendizado autorregulado. Escrever o que se pretende fazer ajuda a refletir antes de iniciar o estudo estimula a consciência e a concentração na atividade. 0 uso do diário também é uma prática recomendada pela pesquisa já que isto pode auxiliar a manter o foco nas metas estabelecidas e também desenvolver a capacidade monitoramento do próprio progresso (MCPHERSON, 1989, 2005 apud MCPHERSON; ZIMMERMAN, 2011, p. 140).

Documentar o que foi realizado é uma boa maneira de conhecer com maior exatidão como se dá o próprio estudo, o tempo leva para realizar as tarefas, onde estão as maiores dificuldades e, possivelmente, promover o autoconhecimento. Como foi falado no início do capítulo, o processo da autorregulação é cíclico e as etapas são

22 HALLAM, S. Approaches to instrumental music practice of experts and novices: Implication for education. In: JØRGENSEN H. e LEHMANN A. C., (Eds.). Does practice make perfect? Current theory and research on instrumental music practice. Oslo, Norway: Norges musikkhøgskole. 1997, p. 89-107. 
interdependentes. 0 uso de um diário, além de auxiliar no planejamento do estudo, pode servir de relatório sobre o trabalho realizado. Esse processo de registrar sua atividade pode estar inserido na fase de execução proposta por Zimmerman, como uma forma de auto-observação.

Provost alerta que pode haver uma dificuldade inicial em fazer o planejamento, decidir e escolher metas claras, e com dificuldade adequada. Contudo, com algum tempo de prática será possível conhecer-se melhor e escolher mais precisamente os objetivos (1992, p. 12). É possível ver informações semelhantes em um recente estudo de Hatfield e Lemyre (2016) que promoveu uma intervenção com estudantes músicos avaliando o uso de diversas ferramentas para estimular a autorregulação na prática desses alunos. Nesta intervenção, os estudantes relataram uma dificuldade em manter o hábito de usar o diário, algo que exigia esforço voluntário, mas os ajudava a refletir e avaliar suas práticas:

Eles [os estudantes] reportaram que usar o diário os fez refletir e avaliar a si mesmos de outra perspectiva, o que tornou mais fácil atribuir as causas dos sucessos e falhas. Eles também reportaram que acharam desafiador usar o diário em no cotidiano, mas quando o faziam, sentiam que isto os permitia ganhar uma maior compreensão do seu desenvolvimento geral (...) Ambos estudantes reportaram também que exigia uma grande dose de empenho para sentar, refletir e avaliar o estudo após um dia inteiro de estudo (HATFIELD; LEMYRE 2016, p. 7) ${ }^{23}$

Importante reiterar que nem todas sugestões levantadas pelos autores da área musical foram adereçadas pela pesquisa empírica. Não há evidências, por exemplo, de qual seria a melhor forma de organizar o estudo, se é melhor começar com estudo técnico, nem se há alguma quantidade de horas ideal, até porque há diversas variáveis em questão (e.g. características pessoais, instrumentais, tipo de música, o estágio de desenvolvimento individual). Apesar de ser comum estruturar o estudo em trabalho técnico seguido de repertório, não há referência na pesquisa que indique como equilibrar uma rotina fixa com a variedade (LEHMANN; JORGENSEN, 2012, p. 681). Há, porém, indicações da psicologia da aprendizagem (em disciplinas acadêmicas) de que uma rotina repetitiva de estudo pode não ser produtiva, e que o estudo intercalado, com

23 Tradução do autor: They reported that using the diary had made them reflect and evaluate themselves in a new way that made it much easier to attribute sources of success and failure. They also reported that they had found it challenging to use the diary on a daily basis, but when applied they felt that it enabled them to gain a greater insight on their overall development (...) Both students reported that it took a great deal of volition after having finished a full day of practice to sit down to reflect and evaluate their day." (2016, p. 7) 
alternância de situações diferentes, traz resultados mais eficazes na retenção e aprendizado a longo prazo ${ }^{24}$ (BJORK; BJORK 2011). Além disso, há informações já bem estabelecidas, como por exemplo a maior eficácia da prática distribuída em comparação com a prática massiva na retenção do aprendizado a longo prazo (BARRY; HALLAM 2002, p. 152; BJORK, BJORK 2011, p. 59).

\subsubsection{Motivação}

A motivação na autorregulação é um dos subprocessos que influenciam o aprendizado, afetando diretamente a escolha os objetivos e a disposição para a realização das tarefas. Neste tópico levanto informações que se alinham com as crenças motivacionais, reunindo o que os autores falam sobre esse aspecto e algumas possíveis sugestões.

Iznaola ressalta a importância de administrar a motivação para sustentar a prática regular e consistente, e fala em dois tipos de motivação: interna e externa. Estas duas quando combinadas e equilibradas alimentam o envolvimento na rotina de estudos. A motivação interna, segundo o autor, pode ser considerada como disciplina, cuja definição seria "a consequência da vontade de agir orientado pelos objetivos, impelido por circunstâncias internas (necessidades não materiais ou espirituais) ${ }^{25 ”}$ (2000, p.22). Já motivação externa pode ser entendida como o dever, as obrigações externas: seja o compromisso de estar preparado para o recital agendado, ter as partes estudadas para o ensaio ou atingir determinado nível profissional. Nesse sentido, ele pode colaborar com a motivação interna, incentivando a seguir com as tarefas quando por alguma razão a motivação interna estiver em baixa.

Iznaola fala também de elementos que afetam o estudo, como as expectativas (implícitas e explícitas) sobre o que podemos/devemos realizar, expectativas estas que podem estimular a motivação, ou podem trabalhar o desenrolar do aprendizado, quando são distantes da realidade. As memórias de experiências passadas também tem o mesmo

24 Há um texto no blog bulletproofmusician.com, onde a clarinetista Chistine Carter destaca resultados de sua pesquisa (dissertação na McGill University) indicando que a prática aleatória no estudo de trechos musicais pode ser mais eficaz que a massiva, além de promover maior foco. Disponível em: http://www.bulletproofmusician.com/why-the-progress-in-the-practice-roomseems-to-disappear-overnight/

25 Tradução do autor: “(...) Discipline (...) is the consequence of a desire to act in a goal-oriented way, prompted by internal circumstances (non-material, or spiritual needs)" (p.22). 
efeito: falhas ou experiências negativas também afetam o estudo quando nos deixamos influenciar por esses pensamentos. Para isso, o autor alerta para o caráter individual do processo de aprendizado ao instrumento, recomenda que haja um realismo honesto com relação às expectativas que estabelecemos e que não se deixe envolver pelas memórias ruins.

A ideia de Iznaola vai ao encontro a de Klickstein (2009, p.105), segundo o qual a motivação é o que nos instiga ao desenvolvimento musical, sendo ela uma combinação de elementos internos e externos. 0 autor traz algumas sugestões para alimentar a motivação: estabelecer objetivos claros (a curto, médio e longo prazo), uso de autofala com frases de suporte e estímulo, ouvir músicas, participar de festivais e concertos. Além disso, destaca que a motivação é influenciada positivamente ao escolher músicas que inspirem ao trabalho e que esteja dentro das próprias possibilidades.

Outro ponto interessante levantado por Klickstein é que alguns músicos acreditam que para produzir algo precisam estar motivados. No entanto, o autor afirma que uma coisa alimenta a outra: a satisfação de ter aprendido algo desperta o ímpeto de seguir adiante com o trabalho. Esta afirmação do autor alinha-se com o que propõe o modelo de aprendizagem autorregulada: a percepção de progresso de uma tarefa pode gerar resultados positivos de satisfação (na fase autorreflexão, terceira etapa do ciclo), que tem influência direta na percepção de autoeficácia e motivação.

Para motivação externa, Klickstein também recomenda envolver-se em compromissos externos, como recitais, gravações, concertos, festivais e concursos além de estabelecer prazos para si mesmo ao organizar o estudo, independente de eventos. Uma sugestão interessante é a de desenvolver trabalho em conjunto com outros músicos, seja música de câmara, improvisação ou mesmo criando um grupo de estudos para simular performances. Em consonância com que o que propõem Mcpherson e Zimmerman (2011), o aspecto social é um dos fatores que influenciam a autorregulação, e o convívio e aprendizado com outros colegas pode ser um grande estímulo para a motivação.

Tanto Iznaola quanto Klickstein ressaltam que há altos e baixos na motivação para a prática musical e é importante saber reconhecer esses momentos e estar munido de estratégias para lidar com eles, equilibrando a motivação interna e externa. 
Provost não aborda diretamente a motivação. No entanto, recomenda que durante o estudo procure manter uma postura de observador, sem alimentar julgamentos vazios (e.g. "meu som é péssimo"; "essa passagem nunca sai") que são nocivos à motivação. No caso, essa autoavaliação sem um julgamento imparcial influenciará negativamente a motivação e consequentemente o engajamento na tarefa.

Lehmann e Jorgensen (2012, p. 681) explicam que a pesquisa sobre motivação para o estudo têm mostrado a importância da motivação intrínseca e extrínseca em suas complexas interações ${ }^{26}$. 0 assunto da motivação na aprendizagem ainda é algo complexo e tem sido investigado com base em diferentes teorias, como a autoeficácia, expectativa/valor ou teoria do fluxo, por exemplo (CAVALCANTI, 2009; ARAUJO, 2015).

Sendo assim, o que o estudante pode fazer para administrar a motivação? Nem sempre é possível influenciar diretamente a motivação, já que há uma grande rede de variáveis envolvidas nesse processo, mas algumas das sugestões levantadas aqui podem ajudar administrar esse aspecto. Por exemplo: descobrir o que nos motiva para a prática, seja escolhendo músicas despertem interesse pessoal, ou mesmo procurando elementos que fomentem essa disposição interna dentro das tarefas que temos que realizar; estabelecer metas claras e tangíveis; tentar encontrar os reais motivos para as falhas e problemas no estudo e não atribuí-la à falta de competência ou capacidade. Ao mesmo tempo, engajar-se em compromissos externos pode ser uma boa maneira de estimular o estudo.

\subsubsection{Estratégias na Fase de Execução}

\subsubsection{Autocontrole}

Mcpherson e Zimmerman (2011, p. 160) apontam que o uso da autoinstrução pode fortalecer habilidade de focar atenção na execução, quando usada na forma de autofala durante o estudo, ou até mesmo aliviar a ansiedade, através de afirmações internas antes da performance. Nielsen (2001, p. 160) observou em sua pesquisa o uso dessa estratégia autorreguladora e mostra que ela pode envolver instruções internas ou externas durante a execução de uma tarefa, podendo auxiliar na concentração, na 
implementação de estratégias ou para sustentar a motivação. Jorgensen (2004) inclui a autoinstrução (self-guide) como uma estratégia de avaliação, já que pode vir também na forma de comentários sobre a execução, o que entraria na terceira fase do ciclo de autorregulação. Isso mostra a interligação entre as fases da autorregulação e é uma das evidências de que a divisão em fases é apenas uma ferramenta para compreensão do processo.

Dentre os autores escolhidos não havia muitas indicações nesse sentido, apenas sugestões de seu uso como suporte para motivação. Klickstein, por exemplo, cita o uso da autofala como forma de alimentar a motivação para o estudo, com afirmações positivas em momentos de preguiça, procrastinação ou desânimo. Sugere o seu uso também na preparação antes do concerto, para administrar os pensamentos que porventura possam diminuir a confiança e aumentar a ansiedade (2009, p. 169).

A pesquisa em expertise musical tem mostrado que a concentração e o esforço mental são características centrais para uma prática eficaz (CHAFFIN; LEMIEUX, 2004, p. 24). Para administrar o foco da atenção os músicos se utilizam de diversos procedimentos, desde escolher local mais apropriado para estudo, usar o metrônomo como auxiliar ou trabalhar em curtas sessões de estudo.

Para tornar o estudo mais prazeroso e evitar distrações, Provost destaca que é importante manter a atenção em elementos específicos durante o estudo, já que a mente desvia-se com facilidade do que não é interessante. Klickstein fala em hábitos essenciais para excelência musical, hábitos esses que devem ser cultivados no estudo, sendo a atenção focada um dos principais (2009, p. 20). Recomenda, ainda, trabalhar este aspecto durante a prática, estabelecendo metas claras e fazendo intervalos quando perceber que a mente está se desviando do trabalho.

Para Ryan, concentrar-se bem durante o estudo permite aproveitar melhor a atividade, o tempo e a energia. Baseando-se em conceitos da filosofia Zen e da Ioga que permeiam todo o seu livro, recomenda trabalhar o que chama de concentração natural, um estado em que a mente está relativamente quieta e disponível para focar em algo que se oferece. Para isso, sugere duas abordagens: uma psicológica e outra fisiológica. A abordagem psicológica utiliza pontos de foco mental, em que se deve voltar a atenção para elementos específicos: movimentos dos dedos, melodia, harmonia, ritmo, estrutura formal e significado intrínseco. A atenção pode ser guiada tanto pela visão, quanto pelo 
som, tato, intelecto ou sensibilidade emocional. A abordagem fisiológica procurar tratar obstáculos como fadiga e stress, através do cuidado com o bem-estar físico. Ryan sugere que uma rotina equilibrada deve incluir atividades físicas regulares, boa alimentação, descanso adequado e práticas de respiração (extraídas da Ioga) (1991, p.16).

Sobre representações mentais na prática musical há diferentes abordagens desse procedimento na literatura e estes levam a várias definições e termos (e.g. visualização, imagética musical, audição, ensaio mental). Mas de forma geral, como mostra Mendonça (2015):

“é a capacidade mental do músico de evocar, resgatar ou recriar em seu
universo interno (mental) uma representação que pode ser auditiva,
visual/imagética, cinestésica, lógica ou uma mistura de todas as anteriores
de forma a causar uma sensação emotiva/sensorial de um objeto ausente,
porém conhecido ou de uma sensação presente no passado
(lembrança/memória)" (2015, p. 19).

Estes recursos mentais não são uma estratégia por si só mas sim uma abordagem no aprendizado que faz largo uso dos processos cognitivos internos, como explicam Lehmann e Jorgensen (2012, p. 682). É usado em diversas situações, por exemplo: no contato prévio com a obra a ser estudada, no suporte a execução através de imagens, na memorização da música sem o instrumento. Segundo estes autores, as pesquisas que comparam a eficácia do estudo mental e o físico ainda têm resultados variados devido a sua complexidade e os diversidade de variáveis (e.g. nível de expertise dos músicos, complexidade da música, diferentes estratégias mentais, familiaridade com a prática mental). Apesar de tudo, a recomendação geral é que se use uma combinação de ambas.

Outra referência principal nesse aspecto, dentro da literatura musical é já citado método de Karl Leimer (GIESEKING; LEIMER, 1972), que aborda a construção da interpretação e da execução ao piano baseado no uso da visualização. Os autores Iznaola, Provost e Klickstein também sugerem o uso da visualização para memorização e leitura à primeira vista, assim como Ryan, que ainda recomenda sua utilização como auxiliar no trabalho da velocidade.

Connolly e Williamon (2004), que discutem a prática de habilidades mentais, apresentam algumas informações semelhantes aos autores violonistas e explicam que essa prática pode ser benéfica para: melhorar o aprendizado e memorização, tornar o estudo mais eficiente, focar a atenção durante a performance, administrar emoções 
negativas, entre outros. No entanto, para que tenha resultados, é importante que esse recurso seja praticado com regularidade, relaxamento adequado e foco na tarefa em questão. Além disso, a eficácia dessas estratégias depende do nível, características pessoais e experiência do músico em empregar esses procedimentos.

As estratégias de ensaio são procedimentos usados na execução das tarefas, sendo que há inúmeros exemplos na literatura. Apesar de sua eficácia depender da experiência pessoal em utilizá-las, o uso de estratégias de ensaio adequadas é de grande importância para a produtividade, sendo portanto essencial conhecer e aplicar vários desses procedimentos até que se crie um repertório pessoal de estratégias.

Jorgensen (2004), cita alguns tipos de estratégias comuns: estudo mental, estratégias parte-todo ${ }^{27}$, estratégias para partes difíceis, estratégias para subir andamento, estratégias para a performance e para distribuir o tempo de estudo. A seguir serão destacadas as principais estratégias abordadas pelos autores violonistas no preparo de repertório para performance. Vale lembrar que não serão analisadas com detalhe, já que o trabalho não é voltado à discussão desse conteúdo específico.

Para facilitar a organização as principais estratégias de ensaio serão apresentadas em 5 diferentes tópicos:

\section{a) Na abordagem de obras novas:}

Pesquisas sobre a prática de experts mostram que, em geral, estes músicos estudam novo repertório partindo de uma visão ampla da obra (ver CHAFFIN e LEMIEUX, 2004). Embora não seja tão comum na prática de estudantes, este procedimento pode beneficiar a compreensão, a coerência interpretativa, a memorização e a resolução de problemas.

Para este primeiro contato com a obra é recomendado entre os autores violonistas a leitura com ou sem instrumento, o uso de algum tipo de análise para compreensão da estrutura musical, a pesquisa sobre a música e seu contexto, além da escuta de gravações disponíveis. Apesar dos autores Provost, Ryan e Klickstein comentarem sobre a escuta de gravações nas primeiras etapas de contato com a música, destaco que é necessário ter cautela, já que isso pode influenciar a compreensão do

27 Consiste em trabalhar a partir de pequenos trechos para montar a obra ou a partir da música inteira, resolvendo os problemas pontualmente. 
conteúdo musical e talvez incentivar a cópia de interpretações, limitando novas ideias. Como explica Ryan, os estudantes mais iniciantes podem se favorecer dessa escuta e aprender com as escolhas dos grandes intérpretes ${ }^{28}$, ao passo que para os mais avançados, talvez seja melhor fazer isso após montar sua visão pessoal da obra trabalhada (1992, p. 198). Fazer isso pode ser uma forma interessante de comparar ideias e procurar abordagens que não tenham surgido durante o estudo.

Provost fala em duas etapas no aprendizado de obras novas: leitura das notas e estudo interpretativo (1992, p.30). Considera que as duas estão interconectadas e que a leitura básica não deve excluir a compreensão dos elementos estruturais da música. Por outro lado, seria pouco proveitoso fazer a digitação de uma música sem nenhuma ideia inicial de como deve soar a obra. Sendo assim, a primeira etapa (leitura das notas) é onde se absorve o conteúdo musical para o ouvido, a mente e para os dedos. Inclui o seguinte:

1) Leitura lenta e identificação de áreas problemáticas;

2) Compreensão do ritmo, solfejando sem o instrumento;

3) Digitação das duas mãos;

4) Trabalho lento com cada frase, não se prendendo em erros, a não ser que sejam recorrentes. Se acontecer pare e entenda causas;

5) Conectar as frases lidas com as anteriores, até completar uma seção, e então revisar se há tensão excessiva, falhas de leitura, dinâmicas ignoradas.

O próximo estágio seria o estudo interpretativo, o qual tem estreita relação com primeira etapa, leitura de notas. Para Provost, uma boa interpretação deve incluir características como: clareza da estrutura, das dinâmicas, dos ritmos, do caráter da música, direcionamento melódico, atenção às indicações do compositor, equilíbrio entre intelecto e emoção do intérprete. 0 mais importante, salienta o autor, é que haja coerência e consistência ao longo da obra.

Ryan deixa bem claro a importância da abordagem mental na compreensão prévia da obra, antes de iniciar o trabalho de digitação e memorização, com o intuito de

28 De fato, praticar tendo como referência um modelo sonoro pode tornar o aprendizado mais eficiente, estimulando a escuta e a avaliação da execução, como sugerem algumas pesquisas (ver Miksza, 2013,p.3 para mais informações). 
buscar a coerência na interpretação de uma música. Ainda que essa concepção se altere ao longo do estudo, o que é algo natural e faz parte do processo, é necessário ter uma boa noção da estrutura e conteúdo da música.

Como referência, Ryan (1992, p. 194) apresenta doze passos para estudar uma obra, que foram adaptados do livro The Pianist's Problems de William Newman (1974). Estes passos podem ser ajustados de acordo com necessidades individuais, mas o autor defende que a estrutura base deve ser "primeiro a música, depois a técnica". Consistem em 12 passos, os quais ele divide em 3 etapas:

I - Criar uma ideia musical: 1) escolher uma música que goste; 2) ler a partitura mentalmente; 3)Absorver a sonoridade, estilo, e caráter (através da leitura à primeira vista, escuta de intérpretes, escuta de músicas relacionadas em outros instrumentos, ler sobre o contexto da obra), 4) Analisar a música, formando uma interpretação preliminar;

II — Trabalhar a técnica: 5) encontrar digitações musicais e naturais ${ }^{29}$,6) Leitura lenta com o metrônomo (usar técnica play-relax ${ }^{30}$ ), 7) Polir trechos difíceis, trabalhar o som, 8) Ler a tempo com e sem metrônomo;

III - Dar vida à música: 9) Memorizar e tocar a tempo, 10) Praticar mentalmente, usar feedback, 11) Refinar a interpretação, 12) Expressar a totalidade da música;

Klickstein (2009, p. 42) apresenta ideias relacionadas e destaca 4 passos ao abordar repertório novo: 1) obter uma visão geral, 2) esquematizar uma interpretação, 3) esquematizar a técnica, 4) pôr em prática o que esquematizou. 0 primeiro passo inclui estabelecer referência auditiva (lendo, solfejando ou ouvindo gravações), pesquisar sobre a obra e preparar a partitura (dividir seções, marcar possíveis problemas, etc). 0 segundo passo serve para estabelecer uma ideia da interpretação identificando aspectos de estilo, ritmo, articulação, etc. 0 terceiro implica em identificar digitações e detalhes técnicos, vinculado à ideia da interpretação estabelecida. Por fim, a execução desse trabalho inclui estudo gradativo de pequenas seções da música;

290 que Ryan fala em natural em seu livro pode ser compreendido como uma digitação que busca equilibrar organicidade, funcionalidade e atender as ideias musicais.

30 Ryan recomenda evitar tensão excessiva e aprender a relaxar a tensão dos dedos quando não é exigido trabalho deles. Para isso recomenda uma prática que chama de Play-relax (tocar e relaxar), para praticar o equilíbrio entre a ativação e o relaxamento muscular dos dedos ao tocar. 
administração do andamento, inicialmente lento com metrônomo (mas não sempre) tendo em mente que estes movimentos serão executados em outro andamento posteriormente; uso da visualização; uso da repetição; conexão entre as seções.

Observa-se que, de maneira geral, há uma linha de pensamento em comum entre os autores: o primeiro passo no trabalho com repertório novo é conhecer a música para obter uma visão geral (solfejando, lendo com/sem instrumento, ouvindo gravações). Dessa forma, pode-se elaborar uma visão preliminar da interpretação, a qual deve guiar a resolução técnico-mecânica, embora esta possa (e costume) ser revisada ao longo do processo.

\section{b) Na resolução de situações complexas:}

Entre os autores é unânime a recomendação de que uma passagem complexa seja dividida em partes mais simples, possíveis de resolver e trabalhar. Nessas situações costuma-se usar o procedimento da repetição, muitas vezes sem a devida atenção. A repetição cria hábitos e automatiza o que se estudou, portanto é necessário ter cautela. Esta é apenas uma das ferramentas disponíveis para o estudo e deve ser usada para assimilar o que se aprendeu.

Klickstein comenta diretamente sobre o uso da repetição e sugere que se trabalhe os trechos buscando 3 repetições corretas: se alguma falhar, recomeçam as repetições; se tudo der certo, pode-se seguir adiante. Posteriormente, os trechos estudados podem ser agrupados. No caso de haver erros recorrentes, não se deve repetir sem corrigi-los. As repetições nunca devem ser feiras sem um propósito, mas sempre ter um objetivo claro e buscar o aperfeiçoamento. 0 autor sugere ainda também o uso de gravações para analisar como está o trabalho.

Para Iznaola a resolução de problemas consiste em 3 passos importantes: identificar, entender e assimilar. Ou seja, reconhecer que há um problema e encontrar onde ele está, compreender os motivos geradores desta situação, buscando soluções e, por fim, ao encontrar a solução, assimilar através da repetição consciente. Sem trabalhar nas outras etapas de identificação e compreensão dos problemas, a repetição só fixará ou tornará o problema pior. Após resolvido, é importante trazer os trechos isolados de volta ao contexto da música para integrar o que foi trabalhado. 
Uma série de procedimentos são apresentados como estratégias de resolução de problemas. Estes, em geral, compreendem a análise da situação, seleção de elementos para estudo isolado (estudar apenas ritmo, vozes separadas, movimentos da mão esquerda/direita), estudo através de agrupamento de notas, ou modificação de alguns aspectos (ritmo, velocidade, articulação).

Klickstein (2009, p. 57), por exemplo, sugere alguns procedimentos: modificar o ritmo; estudar um trecho de trás para frente (começar nas últimas notas e posteriormente começar de notas anteriores), estudar componentes separados (só a melodia, o baixo, mão direita/esquerda, solfejar o ritmo, etc); omitir notas e depois inserir, entre outras. Alguns desses são abordados por Ryan também, como estudo de mãos separadas e a extração de partes da música para estudo detalhado (omitindo vozes ou notas de passagem, por exemplo).

Provost, não sistematiza a resolução de problemas, mas fala que estes podem ser de dois tipos: problemas de ordem mecânica ou de interpretação (1992, p. 35). Inicialmente, recomenda que se observe alguns pontos: o problema vem da mão direita ou esquerda? É um problema de coordenação (quando há movimentos descontrolados, excessivos) ou de reflexo (quando os dedos não se movem rápido o suficiente)? Cada tipo de problema requer um estudo diferente.

A prática da coordenação parte do estudo lento e progressivo, com atenção aos movimentos e ao som produzido. A prática dos reflexos envolve menos controle detalhado sobre os dedos, uso de andamentos mais rápidos, observando mais a fluência, a sensação, do que os detalhes. Para esta última, Provost sugere o estudo com ritmo modificado (tal como Klickstein), ou uma combinação do estudo lento e rápido, procedimento que ele chama de Stop Practice (importado do livro The Art of piano Playing, de George Kochevitsky - $1967^{31}$ ). Essa estratégia consiste em praticar passagens de velocidade dividindo o trecho em grupos de notas menores, que devem ser tocados rápido, mas com um breve espaço de tempo entre eles, que servem como momentos de repouso. Pode ser útil também no estudo de saltos problemáticos (mudanças de posição).

31 Essa estratégia também é citada pelo violinista Robert Gerle (1983, p.14), embora ele não dê esse nome. 
Para os problemas de interpretação, Provost sugere repensar as escolhas que fez com relação à obra ou o trecho em questão. Para guiar esse trabalho, alguns pontos: testar outros fraseados, dinâmicas, timbres, repensar digitações, checar as respirações, rever a intenção musical e estudar a música sem o instrumento para revisar esses aspectos.

Sobre problemas mecânicos, são importantes referências os livros de Abel Carlevaro, particularmente o Escuela de la Guitarra: Exposición de la Teoría Instrumental (1979). Neste livro, Carlevaro apresenta toda uma reflexão e sistematização sobre o uso adequado das mãos no instrumento, que pode ser o diferencial na escolha de uma digitação, na prevenção de problemas e na correção de posições demasiado tensas ou dificuldades de movimentação. A aplicação de seus conceitos pode ser observada na série Guitar Masterclass (4 volumes), na qual apresenta algumas soluções em repertório específico do violão.

A eficácia destes vários procedimentos citados não serão analisados com profundidade, até porque muitos não foram estudados em pesquisas empíricas (algo que seria de grande complexidade para avaliar). No entanto, essa variedade de estratégias pode ser útil para experimentar outras formas de estudar e observar sua funcionalidade na prática individual.

A abordagem racional nessa etapa representa um denominador comum entre os autores. 0 diagnóstico adequado e a busca por soluções são fundamentais na resolução de situações complexas. Ainda assim, perceber ou reconhecer que há um problema por si só já pode ser um desafio e, por isso, o refinamento do trabalho requer uma revisão cuidadosa da performance. Como foi discutido, uma situação problemática nem sempre é aquela em que se é incapaz de tocar uma passagem: uma tensão desnecessária pode ser um problema, um fraseado incoerente pode ser outro. Revisar atentamente e, eventualmente, questionar sua própria execução pode revelar situações não resolvidas, as quais podem exigir tanto o raciocínio lógico quanto a experimentação na busca de soluções.

\section{c) No trabalho com o andamento}

Sobre a manutenção do andamento das músicas no estudo, Jorgensen comenta que há três estratégias comuns para atingir o andamento desejado: iniciar lento e 
aumentar gradativamente; iniciar lento, mas alternar o estudo com andamentos mais rápidos; tocar no andamento do início ao fim. A primeira forma é mais recomendada, mas há uma questão a se colocar: muitas vezes a ativação muscular para se tocar algo lento é diferente de quando se toca rápido, o que pode prejudicar a eficácia do estudo progressivo (WINOLD; THELEN $1994^{32}$ apud JORGENSEN, 2004, p. 94). Portanto, em alguns casos, alternar entre estudo lento e rápido pode ser uma boa maneira de lidar com esse problema, já que permite testar a execução no andamento final. Barros (2008, p. 162) aponta ressalvas sobre esse último procedimento, que apesar de permitir atingir o andamento desejado em menor tempo, pode acumular mais falhas. Para isso, recomenda que esta estratégia seja usada em pequenos trechos da música trabalhada, evitando tocar a música inteira sem ter dominado os movimentos adequados e os diversos elementos da interpretação.

Ryan recomenda evitar tocar no andamento da performance precocemente, estando de acordo com Provost, que reforça a necessidade do estudo lento para consolidar a coordenação (1991, p. 168). Para isso, lembra que o metrônomo é um grande auxiliar na monitoração desse trabalho, já que ajuda a encontrar problemas de ritmo, estabelecer uma pulsação estável (que pode ser flexibilizada posteriormente) e acompanhar o progresso até o andamento estabelecido para performance. Propõe também, assim como Klickstein, que após atingir o andamento estabelecido se estude eventualmente um pouco mais rápido, para que consiga tocar mais tranquilamente. Barros (2008, p. 162) comenta sobre essa última estratégia, que é sugerida também por outros autores $^{33}$, e destaca que deve se usar isto com cautela, de forma que só faria sentido estudar dessa forma se os aspectos expressivos e interpretativos conseguirem acompanhar o andamento.

Klickstein ressalta que o trabalho com metrônomo permite conhecer os limites de andamento que consegue executar. Sugere ainda um procedimento com 5 repetições que poderia ser usado para praticar o aumento do andamento: as duas primeiras repetições em tempo moderado, as duas próximas gradualmente acima e a última no limite. Alerta, no entanto, para evitar repetições excessivas. Enfatiza também outros aspectos: revisar as digitações e movimentos sempre que necessário, inventar

32 WINOLD, H.; THELEN, E. Coordination and Control in the Bow Arm Movements of Highly Skilled Cellists. Ecological Psychology, Vol 6, no 1, 1994, p. 1-31.

33 No caso, ele cita: JOHNSTON. Philip. The practice revolution. Austrália: PracticeSpot Press, 2002. 
exercícios, usar a visualização como ferramenta de suporte para esse estudo, balancear trabalho em seções curtas e longas, e conseguir tocar um pouco acima do que o tempo que usará em performance (2009, p. 51).

\section{d) Na memorização:}

Ryan recomenda a memorização para estudar ou tocar já que esta libera a atenção da partitura permitindo voltar-se a elementos técnicos e expressivos, mas alerta que não deve haver pressa em fazer isso, já que corrigir os erros após memorizados é mais trabalhoso. Segundo o autor, se o aprendizado da obra envolver um estudo da forma, expressão, digitação, naturalmente boa parte da música acaba sendo memorizada (ou seja, usar a análise para facilitar a memorização). Como procedimentos auxiliares, sugere dois: um se baseia principalmente na prática distribuída e, o outro, no uso da visualização. 0 primeiro consiste em tocar a música aprendida (com partitura) por várias noites antes de dormir e, após alguns dias, testar a execução sem ler. Se houver lacunas de memória, revisar aqueles pontos e repetir o processo novamente. Ryan afirma que, como não haverá outras distrações no dia, isso ajudaria a fixar o que estudou na memória ${ }^{34}$. 0 segundo é um procedimento importado da metodologia Suzuki que se utiliza da visualização: tocar fragmentos melódicos curtos (que tenham sentido musical), parar a execução, visualizar previamente o próximo trecho (ouvir internamente), tocá-lo, e continuar o processo até o fim da música (1991, p. 216).

Iznaola relaciona a memorização com a leitura à primeira vista e afirma que muitos dos problemas que afetam a performance dos estudantes têm sua origem na falta de precisão ao estudar diversos elementos da música (notas, duração, métrica, andamento, dinâmica, digitação, fraseado, etc). Comenta também que ao melhorar a leitura, essa precisão se desenvolve e, consequentemente, a memorização também. Ao mesmo tempo, a leitura depende de uma boa memória, já que na execução com partitura a leitura está sempre um pouco adiante. Para desenvolvê-la, Iznaola propõe alguns exercícios de visualização: parte do princípio que se o músico é capaz visualizar uma música/trecho sem o instrumento ou partitura, é possível lembrá-la (2000, p. 16). 0

34 Não me aprofundei para verificar outras referências com relação a isso. Acredito que os efeitos positivos dessa abordagem não seja tanto pelo fato de não haver distrações ao fim do dia, mas sim devido à prática espaçada e os efeitos do descanso e do sono sobre o aprendizado (Lehmann; Jorgensen, 2012 p. 684 comentam sobre esse último aspecto). 
autor faz referência aqui a músicos que utilizavam largamente a visualização como ferramenta de aprendizado, Walter Gieseking, Fritz Kreisler e Alfred Cortot.

Provost destaca que há vários tipos de memória (visual, acústica, motora, intelectual) e que a memorização é mais eficiente quando se utiliza mais de um deles para armazenar informações. É importante também definir o que é para ser memorizado, dentro das necessidades de cada instrumento. No caso do violão ou piano, por exemplo, é preciso memorizar: seções, digitação de ambas as mãos, harmonia, dinâmicas, partes isoladas, além das diferentes linhas (melodia, baixos, voz intermediária). Lacunas de memória nesses aspectos podem gerar confusão e possíveis falhas.

Provost cita algumas informações da pesquisa científica sobre a memorização. Por exemplo: a prática distribuída é mais eficaz na retenção de informações do que um longo período de estudo; o emprego de alguma forma de análise antes de estudar melhora o aprendizado; estabelecer relações e encontrar padrões no conteúdo estudado auxilia a memorização; uma vez memorizado, só é necessário estudar ocasionalmente para manter (1992, p.27). Como estratégia de memorização, Provost recomenda também uso da visualização, já que ela estimula o uso de diversas memórias. 0 autor propõe exercícios para praticar este procedimento em melodias/escalas, texturas contrapontísticas e homofônicas. Além disso, propõe sugestões para a memorização de uma música simples, incluindo a repetição/teste/revisão (desde frases, pequenas seções e a música inteira), o uso da análise e a prática de trás para frente ${ }^{35}$ (iniciar das partes finais e ir adicionando as anteriores até chegar ao começo).

Há uma diferença entre as sugestões de Ryan e Provost: o trabalho de repetição/teste que Provost cita é realizado em seções da música e trabalhado de um dia para o outro. Ao que parece, esta prática serviria mais para situações em que há necessidade de memorizar rápido e de maneira ativa. Segundo o autor, em poucos dias é possível reter o trecho que se propôs a memorizar, e, aos poucos é possível trabalhar com outras seções até completar a música. Embora o autor sugira esses passos como um exercício a ser realizado em músicas simples após ter estudado a estrutura e digitações, acredito ser arriscado iniciar memorização de um repertório mais complexo sem ter

35 David Russel comenta também sobre o uso desta estratégia para memorizar. (ver item 138 em CONTRERAS, 1998) 
definido e apurado vários detalhes da música. Já o trabalho que Ryan propõe parece exigir prazo mais longo, pois é feito ao longo de dias e só seria realizado após o estudo aprofundado da música, a resolução dos problemas e detalhes interpretativos. Ryan não se mostra muito a favor da memorização forçada (1992, p. 216) e defende o trabalho gradativo (que ele chama de "natural") de retenção pela compreensão da música e repetição (prática) distribuída.

Um ponto em comum e relevante entre os autores é a recomendação de estudar e conhecer previamente a música, sua estrutura, as digitações e outros vários detalhes para que a memorização seja mais rica. Além disso, o citado uso da visualização é uma excelente ferramenta de absorção e verificação do conteúdo memorizado. No entanto, algumas dessas práticas sugeridas pelos autores podem não ser tão eficazes. 0 trabalho com a repetição, por exemplo, se não tiver um foco específico e não for realizado com atenção pode não funcionar em situações de stress (e.g. em apresentações, testes), tal como aponta Klickstein.

Klickstein apresenta informações sobre memorização com referências na pesquisa empírica (Hallam, $1997^{36}$, Aiello; Williamon, $2002^{37}$ ) e ainda aponta estratégias para esta atividade $(2009$, p. 82). 0 autor organiza esses procedimentos de acordo com quatro estágios da memorização: 1) percepção, 2) enraizamento, 3) manutenção e 4) recordação. No estágio de percepção é onde se cria uma visão global da obra, traçando relações, encontrando padrões, mapeando interpretação e detalhes técnicos. 0 estágio de enraizamento consiste em armazenar: selecionar partes a memorizar, distribuir em sessões de estudo, visualizar e executar pequenos trechos que aos poucos devem ser agrupados, usando múltiplas memórias. A manutenção é importante aspecto do processo, já que a música memorizada requer revisão e apenas tocá-la ocasionalmente não garante isso. Aqui o autor recomenda o estudo mental, a prática da performance e a revisão dos elementos da música. A etapa de recordação é o estágio final, em que se é capaz de relembrar a música de maneira lúcida e flexível, sendo possível começar de qualquer lugar, tocar partes separadas e até alterar detalhes (andamento, articulação,

36 HALLAM, S. The development of memorisation strategies in musicians: Implications for education. British Journal of Music Education, Vol. 14, 87-97, 1997.

37 AIEllO, R.; WILliamon, R. Memory. In R. Parncutt, \& G. McPherson (Eds.), The science and psychology of music performance. New York: Oxford University Press, 2002, p. 167-181. 
dinâmica). Apesar disso, Klickstein é bem claro: não precisa tocar sempre de memória. Se não está seguro, é melhor usar a partitura e tocar bem.

Há vários estudos da psicologia cognitiva sobre o funcionamento da memória humana e diferentes modelos sobre seu funcionamento ${ }^{38}$. Um dos modelos tradicionais propõe três sistemas de armazenamento: sensorial, curto prazo e longo prazo (ATKINSON; SHIFFRIN $1968^{39}$ apud STERNBERG, 2010, p.158). Sendo a memória um processo, ela opera através dos mecanismos de codificação, armazenamento e recuperação, através dos quais as informações podem ser representadas e acessadas. A representação mental da música é formada em diferentes níveis, desde o auditivo, o visual e o cinestésico, dentre os quais se pode alternar a atenção durante a execução, (GINSBORG 2004, p. 128). Diferentes estratégias podem contribuir para a formação dessa representação e, dependendo das preferências pessoais dos músicos, estes podem trabalhar a memorização priorizando um ou outro aspecto sensorial. Apesar disso, um elemento fundamental é fazer uso de estratégias analíticas (ou conceituais), que ajudam a compreender o material memorizado e facilitar a performance.

A visão dos autores músicos sobre a memória, de maneira geral, tem relação com os estudos da psicologia cognitiva. Sua abordagem, no entanto, não é uma reflexão aprofundada sobre o processo, mas sim uma visão mais prática, que é uma referência de como trabalhar esse aspecto no estudo. Vale lembrar que algumas de suas recomendações podem não ser eficazes em todos os casos, e podem não funcionar de maneira semelhante para todas as pessoas já que o uso de estratégias depende da tarefa em questão e da experiência pessoal.

\section{e) No preparo para a performance:}

Sobre a preparação de músicas para a performance Provost ${ }^{40}$ e Klickstein consideram necessária uma prática específica, que é diferente da prática onde se aprende e desenvolve a obra. As estratégias que eles apresentam se baseiam

38 Pode-se ler mais sobre teoria e modelos de memória no Capítulo 5 do livro Psicologia Cognitiva, de Robert Sternberg, (2010).

39 ATKINSON, R.C.; SHIFFRIN, R.M. Human memory: A proposed system and its control processes". In: SPENCE, K.W.; SPENCE, J.T. The psychology of learning and motivation, Vol 2. New York: Academic Press. 1968, p. 89-195.

40 Aqui a referência de Provost (1994) é o livro The art and Technique of performance. 
principalmente na simulação da situação de performance, auto-observação e avaliação (do desempenho, comportamentos, pensamentos e sintomas fisiológicos), além da exposição gradativa a situações de apresentação pública.

Provost fala que ser capaz de tocar uma obra na sala de aula/estudos não significa que ela está apta para a performance. Para ele, há duas categorias de estudo: o aprendizado (learning practice) e a prática da performance (performing practice). A prática da performance deve focar em 4 pontos: 1) Estabelecer os objetivos de uma boa performance, deixando claras as expectativas, verificar sua viabilidade e a partir disso realizar o estudo necessário para atingi-las; 2) Prevenir-se contra interferências, ensaiando em diferentes situações de iluminação, temperatura, cadeiras e com a roupa de concerto; 3) Identificar o que acontece na performance monitorando e avaliando como a situação de palco afeta a execução (houve diminuição da precisão? as ideias musicais estão claras? As mãos tremem? Qual nível de ansiedade?); 4) Fazer testes em público (road test) para saber qual nível de performance da obra (1994, p. 38).

Após avaliar as expectativas que temos para a performance, como a ansiedade de palco afeta a execução e qual o nível de performance a obra se encontra, será possível identificar quais mudanças são necessárias no estudo para o preparo adequado. Além dessas informações, Provost discute vários aspectos da ansiedade de palco, sintomas/ comportamentos comuns e estratégias para lidar com ela (e.g. relaxamento progressivo, meditação, autofala, dentre outros).

Ryan sugere como preparo a exposição gradativa à situação de performance, que pode iniciar com o uso da visualização como estudo da performance, a realização de gravações, pequenas audições para pessoas próximas e tocar previamente no local do concerto.

Klickstein dedica uma seção de seu livro a assuntos de performance, com orientações para antes, durante e depois da apresentação, discussão sobre a ansiedade de palco, estratégias de preparação, administração e desenvolvimento da habilidade para performance. Assim como Provost, fala que uma boa performance não é produto apenas do bom estudo das músicas e que o preparo para a performance deve abranger 5 aspectos: artístico, técnico, mental/emocional, físico, organizacional. Uma sugestão interessante que apresenta é a de montar grupo de estudos de performance, como um laboratório para simular apresentações e compartilhar feedback entre os colegas. 0 
autor fornece ainda questionários que podem guiar a autoavaliação sobre a performance (2009, p. 204) estimulando a visão objetiva, a correta atribuição de causa e a planejamento do estudo para corrigir os problemas.

A maneira como os músicos se preparam para a performance em palco ainda tem sido pouco investigada na pesquisa científica, segundo explicam alguns autores (BARRY; HALLAM, 2002, p. 157; LEHMANN; JORGENSEN, 2012, p. 684). Daniel (2001), mostra que pode ser benéfico estudar o comportamento de palco através de vídeos, já que é mais fácil observar através do registro audiovisual, do que simplesmente contar com a memória do evento, geralmente distorcida pela ansiedade e tensão. Além disso, autoavaliações escritas podem ajudar a uma avaliação mais precisa e produtiva, algo que os professores podem usar com alunos, por exemplo.

\subsubsection{Auto-observação}

O processo de autorregistro pode incluir o uso de um diário como relatório do estudo, conforme explicado no tópico sobre planejamento (p.47). Ao registrar o que está sendo estudado, reflexões ou soluções encontradas, fica mais fácil monitorar o progresso e analisar a maneira como se estuda.

Na prática musical outra forma interessante de registro para a auto-observação é a gravação audiovisual, uma ferramenta eficaz recomendada pelos autores Provost (1992, p. 38) e Klickstein (2009, p. 16). Esta é uma possibilidade que se tornou muito acessível nas últimas décadas devido a maior disponibilidade de dispositivos de gravação, sendo possível atualmente registrar áudio e vídeo com apenas um aparelho celular (smartphones). 0 registro de performances em vídeo pode auxiliar a avaliação mais realista do desempenho e ajudar a direcionar os estudos.

Pesquisadores recomendam limitar o monitoramento aos processos principais ou aos seus resultados porque o excesso dele pode atrapalhar a performance, principalmente quando se enfatiza o monitoramento dos resultados negativos ao invés dos positivos (ZIMMERMAN, 2000, p. 20). Monitorar a execução das tarefas na prática musical é algo bastante complexo, o que pode sobrecarregar os mais inexperientes ou levar a uma observação superficial. Ao se estabelecer objetivos claros fica mais fácil 
monitorar a execução, já que se delimita o que deve ser observado (MCPHERSON E ZIMMERMAN, 2011, p. 161).

Os problemas durante o estudo podem ser de ordem técnica ou interpretativa, segundo explica Provost. Para isso os músicos podem se utilizar de processos de autoexperimentação, para testar possibilidades, encontrar as causas dos problemas, explorar diferentes soluções ou elaborar novas ideias para as músicas, através da variação proposital de elementos como ritmo, andamento, dinâmica, articulação e timbre. Um ponto que relacionado a esse processo é discutido por Klickstein (2012, p.54). 0 autor comenta que a atividade artística costuma lidar com problemas criativos, os quais requerem outra forma de raciocínio, já que nem sempre há apenas uma solução. Para esses problemas seria mais adequado um raciocínio mais aberto à criação de possibilidades, movido principalmente por perguntas abertas (e.g. "E se eu tentar tocar essa frase de outra forma?") do que pela busca de respostas exatas. Esse forma de pensar corresponde ao modo divergente raciocínio, característico da atividade criativa, em oposição ao modo convergente, que é mais focado na busca da solução correta para um determinado problema, através da avaliação e uso da lógica.

No processo de construção da interpretação é frequente que haja uma revisão das escolhas. Provost sugere para isso alguns tópicos que podem guiar essa reflexão, por exemplo: procurar diferentes maneiras de fraseado, revisar a intenção musical, testar diferentes timbres, mudar as dinâmicas (treinando o oposto, a princípio) e estudar sem o instrumento já que o problema pode estar na compreensão e não na execução.

\subsubsection{Estratégias na Fase de Autorreflexão}

Nesta etapa estão envolvidos os processos de autorreflexão, que podem se alinhar em dois tipos: autojulgamento e autorreação. Estes são, respectivamente, os processos pelos quais os estudantes avaliam seu trabalho e as reações a esses julgamentos.

Um pensamento comum entre os autores é a importância de cultivar uma postura de observador durante o estudo, sem julgamentos depreciativos, em um estado de vigilância crítica para perceber os problemas e refletir sobre suas causas. Iznaola afirma que a base para o bom estudo é o equilíbrio interno, um estado de alerta/prontidão para 
a atividade intelectual, sem tensão emocional, mas aguçado pela curiosidade. Para isso, recomenda que não se deixe abalar por altos e baixos que podem surgir, mantendo um distanciamento emocional, observando de forma realista o que acontece sem se condenar, quase como cientistas em um laboratório.

Dentro da sua abordagem que propõe uma autoconsciência no estudo, Ryan sugere desenvolver um estado de consciência não crítica (noncritical awareness) e não se preocupar antecipadamente com os resultados do que está tocando, mas se envolver com o momento presente (1992, p. 17). Esse distanciamento emocional também é citado por Klickstein (2009, p. 109), que acredita ser essencial para a atividade criativa não se deixar levar pelos resultados bons ou ruins, mas estar principalmente focado no processo de aprendizado.

Manter o foco no processo do estudo é uma forma interessante de evitar a procrastinação e de manter-se engajado no caminho para as metas estabelecidas, já que na prática musical os resultados podem levar um longo prazo para se concretizarem. Enxergar um projeto longo (e.g. o preparo de um concerto) como uma série de pequenos passos realizáveis torna a tarefa menos difícil e pode ter efeitos positivos na disposição e motivação para executar o plano traçado.

Klickstein aborda em seu livro a autoavaliação com foco em diferentes aspectos, seja avaliando as tarefas no estudo, o estudo como um todo ou performances específicas (ou seja, avaliação do processo e do produto). Para o autor, a capacidade de autoavaliação é fundamental na identificação dos próprios pontos fortes e fracos.

Provost (1992, p.9) e Klickstein (2009, p.110) alertam para evitar observações negativas durante o estudo (e.g. "Meu som está péssimo", "Estou errando tudo"). Klickstein alerta que esses autojulgamentos depreciativos podem vir acompanhados de reações que dificultam a identificação e correção dos problemas. Ao invés de procurar os reais motivos causadores dos problemas, o músico pode pensar "Não tenho talento", "Outras pessoas têm facilidade", o que prejudica sua maneira de estudar e só alimenta o problema. No lugar disso, seria mais interessante promover observações que levem a refletir como está tocando e o que precisa ser feito (e.g. "Minha mão está tensa nessa passagem”, “Essa digitação não está funcionando bem”, “O que posso fazer para resolver isto?"). 
Essas são as reações de adaptabilidade da qual fala Mcpherson e Zimmerman (2002, p. 162). As reações adaptativas podem guiar para novas formas de regular o estudo, como buscar outras estratégias. As reações defensivas são aquelas que tendem a limitar o desenvolvimento e o engajamento na atividade.

Esses aspectos discutidos pelos autores estão diretamente relacionados com a motivação, que é influenciada pelos julgamentos que fazemos e atitude que tomamos em relação às falhas e sucessos no estudo individual. Novamente, os diferentes processos se mostram entrelaçados, evidenciando que a autorregulação do comportamento é um processo complexo que funciona como um todo, e essas divisões apenas nos ajudam a compreendê-la.

Klickstein fornece modelos de tabelas para avaliação do estudo e das performances $(2009$, p. 113, 204), cobrindo vários aspectos discutidos ao longo do livro. Dessa forma incentiva o diagnóstico real do seu estudo, a busca pelas falhas e as prováveis causas, além da procura de ajuda externa quando necessário (professor, colegas, livros, etc). 0 diário de estudos (já citado na seção sobre planejamento), pode ser também uma ferramenta útil para a autoavaliação, já que este material seria usado também como relatório do que foi feito.

Fica evidente na fala dos autores a importância da autoavaliação que deve ser objetiva e não-depreciativa. Além disso, são destacados o cultivo à atenção e à autoconsciência durante o estudo, para identificar dificuldades e tratar as falhas como elementos a serem desenvolvidos, para os quais se deve procurar as maneiras adequadas de fazê-lo.

\subsection{Síntese das estratégias apresentadas}

Como um resumo geral das estratégias que foram abordadas aqui, pode-se conferir a tabela 1 a seguir. 
Tabela 1: Resumo das estratégias relacionadas às fases da autorregulação

\begin{tabular}{|c|c|c|}
\hline ETAPA & $\begin{array}{l}\text { Processos } \\
\text { envolvidos }\end{array}$ & Estratégias \\
\hline \multirow{2}{*}{$\begin{array}{ll}\text { Fase } & \text { de } \\
\text { Preparação } & \end{array}$} & $\begin{array}{l}\text { Análise da } \\
\text { Tarefa } \\
\text { (metas, } \\
\text { planejamento } \\
\text { estratégico) }\end{array}$ & $\begin{array}{l}\text { - Estabelecer Metas claras (curto, médio e longo } \\
\text { prazo) } \\
\text { - Organização/agendamento: fazer sessões curtas de } \\
\text { estudo com intervalos, incluir aquecimento, estudo de } \\
\text { técnica, distribuir as tarefas, adequar o tempo de estudo, } \\
\text { - Organizar ambiente de estudo } \\
\text { - Escolher estratégias adequadas } \\
\text { - Registrar o planejamento (diário de estudo) }\end{array}$ \\
\hline & $\begin{array}{l}\text { Crenças } \\
\text { motivacionais } \\
\text { (autoeficácia, } \\
\text { expectativas, } \\
\text { valor intrínseco) }\end{array}$ & $\begin{array}{l}\text { - Escolher adequadamente as músicas a estudar } \\
\text { (baseado em interesse pessoal, nível de dificuldade } \\
\text { compatível) } \\
\text { - Agendar compromissos (recitais, tocar para outros } \\
\text { músicos) } \\
\text { - Estabelecer metas claras e tangíveis } \\
\text { - Rever as expectativas }\end{array}$ \\
\hline \multirow[t]{2}{*}{$\begin{array}{ll}\text { Fase } & \mathrm{de} \\
\text { Execução } & \end{array}$} & $\begin{array}{l}\text { Autocontrole } \\
\text { (autoinstrução, } \\
\text { foco de atenção, } \\
\text { visualização, } \\
\text { estratégias de } \\
\text { ensaio) }\end{array}$ & $\begin{array}{l}\text { - Uso da autofala como instruções claras durante o } \\
\text { estudo, reforço para a atenção, suporte emocional } \\
\text { - Atenção/concentração: fazer pausas regulares, } \\
\text { manter foco em elementos específicos do estudo } \\
\text { - } \quad \text { Representações Mentais: uso da visualização como } \\
\text { suporte na memorização, na leitura à primeira vista, no } \\
\text { preparo para performance, na elaboração interpretação } \\
\text { - Estratégias de ensaio: uso de variadas estratégias } \\
\text { para a abordagem de obras novas, para a resolução de } \\
\text { problemas, para elevar o andamento, para memorização, } \\
\text { e no preparo para o palco }\end{array}$ \\
\hline & $\begin{array}{l}\text { Auto-observação } \\
\text { (Monitoramento, } \\
\text { autorregistro) }\end{array}$ & $\begin{array}{l}\text { - Registro: usar diário ou relatório sobre o estudo, } \\
\text { gravações para acompanhar progresso e revisar } \\
\text { detalhes } \\
\text { - Monitorar estado de atenção e a disposição } \\
\text { física/mental } \\
\text { - Autoexperimentação: testar opções (estudo } \\
\text { aberto) na resolução de problemas interpretativos, na } \\
\text { busca por outras ideias }\end{array}$ \\
\hline
\end{tabular}




\begin{tabular}{|c|c|c|}
\hline $\begin{array}{l}\text { Fase de } \\
\text { Autorreflexão }\end{array}$ & $\begin{array}{l}\text { Autoavaliação, } \\
\text { atribuições de } \\
\text { causa, } \\
\text { autossatisfação, } \\
\text { adaptabilidade }\end{array}$ & $\begin{array}{l}\text { - Avaliação do processo e do produto: avaliar o } \\
\text { progresso na sessão de estudo, no dia/semana, e } \\
\text { também avaliar o resultado em performances } \\
\text { específicas, ou o desempenho em performances no geral } \\
\text { - Observar sem julgamentos depreciativos } \\
\text { - Refletir sobre as causas os problemas e buscar } \\
\text { soluções } \\
\text { - Verificar a necessidade de mudanças plano: avaliar } \\
\text { o planejamento e a execução das tarefas, procurando } \\
\text { modificar o que não está funcionando }\end{array}$ \\
\hline
\end{tabular}

\subsection{Estratégias de estudos em entrevistas com músicos avançados}

Há pouca investigação (entrevistas, estudos de caso) sobre a prática dos músicos de elevada expertise ou de carreira internacional, como explicam CHAFFIN el al $\left(2002^{41}\right.$ apud BARROS, 2008, p. 70). Segundo os autores, é possível que essa dificuldade seja devido à agenda ocupada, pouco tempo livre para a prática ao instrumento ou mesmo uma relutância em expor seu momento de estudo, já que fazer isso envolve também revelar hábitos e limitações pessoais. Além do que isso envolveria desfazer o pensamento mítico sobre o artista, de que estes têm algum dom divino que os poupam do trabalho necessário para a realização musical.

Como suporte a esse aspecto, acrescento aqui duas referências de pesquisas recentes no âmbito da pós-graduação no Brasil que evidenciam o estudo de músicos de alto nível, sendo um deles com violonistas e outro com clarinetistas.

Mendonça (2015) realizou um trabalho sobre representações mentais na performance e baseou-se em entrevistas com importantes nomes do violão (professores e concertistas). Apesar de se voltar especificamente às práticas mentais, nas entrevistas é possível evidenciar estratégias de estudo utilizadas por esses músicos.

Na abordagem de uma nova obra, Mendonça destaca (2015, p. 48) que não há entre os entrevistados um processo analítico padrão, já que a abordagem depende da obra que será estudada. Apesar de diferenças entre os violonistas entrevistados, todos

41 CHAFIN, R.; IMREH, G.; CRAWFORD, M. Practicing perfection: memory and piano performance. Mahwah. NJ: Erlbaum, 2002. 
relataram partir de uma leitura geral para conhecer a obra em questão, momento em que ocorre uma análise prévia e que permite identificar trechos potencialmente problemáticos.

Eduardo Fernandez fala da importância de compreender a obra:

(....) o primeiro que faço é tentar entender musicalmente como funciona a peça, eu diria, e depois a questão seria como revisar isso fisicamente no instrumento, aí vem a questão dedilhado entre outras coisas. Eu tento definir todo gesto musical antes de tocar uma nota! Basicamente com a experiência você faz isso muito rápido, você tem uma definição provisória, uma hipótese e trabalha com isso até que novas ideias vêm e modificam a proposta inicial e assim vai aprofundando e descobrindo coisas. (MENDONÇA, 2015, p. 43)

Eduardo Isaac, idem:

Primeiramente chegar à obra sem preconceitos e partir sempre da certeza musical e não de uma análise mecânica, ou seja, sentir que o violão, em todo caso, vai ser o meio que eu tenho, e talvez quanto mais habilidade tenho, para dar sentido a essas certezas musicais. (MENDONÇA, 2015, p. 45)

Os participantes foram questionados sobre o estudo sem o instrumento e relatam o uso desse procedimento em maior ou menor grau.

Daniel Wolff, por exemplo, explica que estudar sem o instrumento é algo constante para ele, já que diversos compromissos o impedem de estar com o violão em mãos, sendo, portanto, um procedimento útil e necessário. Já Mario Ulloa, Edelton Gloeden e Fábio Zanon tendem a estudar sem o violão de forma mais intuitiva, sem planejamento. Por outro lado, Eduardo Meirinho é adepto do estudo por reflexão, no qual se visualiza a execução mentalmente (como proposto por Gieseking; Leimer, 1972).

Eduardo Fernandez e Álvaro Pierri destacam que essa forma de estudo mental acontece com o instrumento ou não, e faz parte do trabalho reflexivo. Ele ocorre, por exemplo, ao pensar o fraseado ou desenvolver uma ideia, para a qual a execução física seria uma prova ou teste dessa ideia. Eduardo Isaac ressalta também que, estando distante do meio físico o qual faz a obra soar, é possível ser mais ambicioso e criativo na construção da interpretação e expressividade.

É possível ver que o uso dessa estratégia é variado entre os entrevistados, o que evidencia as habilidades metacognitivas características do músico expert, que tem 
consciência das suas possibilidades e usa as diversas estratégias de estudo de acordo as exigências da situação. Novamente, fica claro aqui que o estudo mental não é apenas um procedimento, mas uma abordagem ao aprendizado. Percebe-se também na fala dos violonistas um equilíbrio entre o estudo com e sem instrumento, algo que é sugerido pelos pesquisadores, como Jorgensen (2004, p. 88).

Sobre o processo de memorização, há diferentes procedimentos entre eles. Alguns relatam não se preocupar com a memorização, alegando que ela ocorre naturalmente no processo de estudo. Como esses violonistas partem de um trabalho sempre analítico, através da compreensão do funcionamento da obra e suas as partes, revisão de digitação, construção da interpretação e expressão, acredito que esse estudo crie uma representação mental que os ajuda a memorizar sem grande esforço.

Estratégias específicas de memorização são utilizadas quando necessário, como no caso de um repertório muito complexo, ou quando há alguma dificuldade específica. Os violonistas relatam alguns procedimentos como estudo por seções, uso da visualização e uso da análise. No entanto, se necessário, tocam com a partitura, principalmente quando não há tempo para trabalhar a memorização devidamente, tal como relata Zanon (2015, p. 74).

Nesse material não há informações diretamente voltadas ao planejamento e avaliação do processo de estudo, mas os comentários revelam um pouco de suas estratégias de ensaio e construção da interpretação. No entanto, essas características ficam evidentes em outro trabalho que investiga a prática de clarinetistas experts, relatado a seguir.

Alves (2013) realizou entrevistas com clarinetistas brasileiros de alto nível para investigar os fatores determinantes na construção da expertise desses participantes, analisando as estratégias de gerenciamento, manutenção e regulação de suas performances. Baseado nos resultados, o autor defende que a performance expert pode ser construída por meio do refinamento dos processos cognitivos envolvidos na preparação da própria performance. As entrevistas realizadas permitiram identificar elaborados mecanismos de preparação na performance dos participantes, como o planejamento, análise, avaliações e automonitoramento da performance para obter melhores resultados. Estes processos se desenvolveram ao longo da formação, o que fica 
claro quando os entrevistados comparam a maneira de estudar atual com os hábitos no início de suas carreiras.

Vários elementos da autorregulação e metacognição podem ser deduzidos de suas falas:

- Análise e Planejamento do estudo: análise prévia da obra a estudar para mapear possíveis dificuldades, compreender a estrutura geral da obra (principalmente em partes de orquestra); estudo objetivo (metas claras) e detalhista; administração do tempo;

- Autoavaliação: constante feedback (seja interno, através da escuta atenta, ou externo, com ajuda de gravador, por exemplo), uso de gravações de outros intérpretes como referência para estudo; revisão das estratégias utilizadas de acordo com o progresso do aprendizado;

- Estratégias de ensaio: tal como estudo lento, escolha e elaboração de exercícios;

- Estratégias de motivação: engajar-se em desafios, festivais, concursos;

- Fatores Sociais: nos anos iniciais e de formação, contaram com motivação dos pais, estímulo do convívio social e dos professores;

- Consciência do processo de aprendizado e características individuais;

Um dos participantes relata o trabalho em uma obra específica e seu relato evidencia procedimentos como a análise prévia, estabelecimento de metas, planejamento, administração do tempo:

Eu fiz um reconhecimento nos primeiros meses da peça, eu fui escaneando a peça; e reconhecer a peça como um todo, entender quais são as grandes armadilhas, onde estão as passagens mais difíceis, onde eu vou precisar de mais tempo; então eu fiz um reconhecimento nos primeiros meses da peça, eu fui escaneando. O processo foi assim: saber as notas para depois ir colocando um pouco mais dos ritmos corretos, das dinâmicas que iam entrando. Isso foi de tempo em tempo. (....) Eu lembro que no ano anterior eu tinha estabelecido como meta que eu queria começar o ano sabendo as notas; (...) Não acho que eu tenha feito, assim, um planejamento lá no começo e mantive-o a fio. Eu fazia uma parte do planejamento e resolvia, e pensava: qual vai ser a próxima agora? (2013, p. 56)

Fica evidente aqui, através dos trabalhos sobre a prática de músicos avançados, que estes revelam ter conhecimento sobre seus processos de aprendizagem, o que colabora na regulação do estudo e na utilização flexível de estratégias em direção aos objetivos. 
Apesar disso, é importante ter em mente também que, embora a maneira de estudar dos expert seja referência, a abordagem nos diversos níveis de aprendizagem será diferente. Observa-se, por exemplo, que muitos desses profissionais não necessariamente planejam, ou não o fazem de forma explícita, certamente porque já têm maior conhecimento de sua maneira de aprender. Isso não quer dizer que os estudantes não devam planejar. Um estudante de nível intermediário, por exemplo, ainda não tem experiência suficiente e está ainda em processo de conhecimento de estratégias de estudo, de forma que futuramente poderá saber o que melhor funciona para si. Sendo assim, cada etapa do desenvolvimento deve ter abordagens adequadas às suas necessidades, sendo fundamental o acompanhamento de um professor nos estágios de formação. 


\section{ETAPA PRÁTICA: aplicação das estratégias na otimização do estudo}

A experiência prática realizada no trabalho teve como objetivo observar a aplicação das estratégias estudadas na otimização da rotina de estudos pessoal. Esta etapa iniciou com uma autoavaliação dos hábitos de estudo, identificando aspectos positivos e deficiências que poderiam direcionar o planejamento inicial e a escolhas de estratégias.

Como referência para autoavaliação foram utilizados os questionários elaborados nos trabalhos de Araújo (2015) e Miksza (2011), voltados à investigação dos comportamentos autorreguladores no estudo de músicos avançados e estudantes. Segundo os autores, estes questionários poderiam ser usados tanto por pesquisadores, em trabalhos e intervenções futuras, quanto por professores, na avaliação dos hábitos de seus alunos, cujos resultados poderiam guiar a elaboração de aulas e planos de estudo, por exemplo. Araújo afirma ainda que os próprios estudantes poderiam se utilizar dessa ferramenta para verificar que estratégias poderiam ser adotadas para aumentar a eficiência de seu estudo (2015, p. 138).

Os trabalhos desses e outros autores ${ }^{42}$ são uma importante busca por métodos adequados de investigação dos comportamentos de estudo na prática musical. Uma crítica que se faz às pesquisas sobre a autorregulação no aprendizado musical é que embora se utilizem dessa teoria como referência, os métodos utilizados não são adaptados à atividade musical e sim importados diretamente da pequisa em aprendizado acadêmico. No caso, os questionários usados enfatizam características específicas do aprendizado musical.

Foi utilizado também, como referência da área musical, um questionário para avaliação da rotina de estudos proposto por Klickstein (2009) que adereça vários aspectos da prática musical e que podem servir de ponto de partida para rever a maneira como se estuda.

42 Há outros trabalhos com questionários e entrevistas que podem servir de referências para avaliação de estratégias de estudo, comportamentos autorreguladores, autoeficácia como em Hatfield e Lemyre (2016) com uma intervenção que promovia a utilização de estratégias e ferramentas autorreguladoras em estudantes de música, ou Cavalcanti (2009), que investigou a autoeficácia dos estudantes de música em curso superior. 
Após a avaliação e a reflexão inicial sobre os próprios hábitos de estudo, foi realizado um planejamento geral, incluindo: principais aspectos a serem otimizados no estudo, repertório a ser estudado ao longo do período, agendamento de compromissos e planejamento da primeira semana de estudos.

Ao longo do processo, os procedimentos diários seriam: checar a programação de estudo para o dia, modificar o que for necessário, registrar o que foi feito, fazer uma breve avaliação do dia de estudo (o que foi bom/ruim, como foi a concentração, o nível de exigência das tarefas, houve alguma fadiga/dor, quais modificações em relação ao plano, quais foram os progressos) e definir o trabalho do dia seguinte. A programação contava também uma revisão semanal, compreendendo: avaliação do que foi realizado e planejamento da próxima semana (distribuição das tarefas, agendamento, metas).

As ferramentas auxiliares nesse processo foram escolhidas de forma a facilitar o acesso, registro e processamento das informações no momento de avaliar o estudo e também na elaboração da dissertação. Para tal, a preferência foi usar aplicações digitais disponíveis para smartphone e web. No entanto, após pesquisar e testar algumas opções encontradas, percebi que poucos softwares ou aplicações servem de suporte exclusivo para a atividade musical. Alguns registram apenas o tempo de estudo, outros funcionam como simples agendas ou listas de tarefas ${ }^{43}$.

Uma opção que considerei para este trabalho era a aplicação Cadenza, que faz parte de uma coleção de ferramentas digitais desenvolvidas através da colaboração das instituições Concordia University, Queen's University e The Royal Conservatory, no Canadá, com suporte de vários professores e pesquisadores ${ }^{44}$. A intenção desse recurso é promover a autorregulação nos estudantes de música e criar maior interação entre alunos, pais e professores nas sessões de estudo, através de ferramentas digitais, que incluem planejamento, diários e gravações. A ferramenta, portanto, mostra um grande potencial de utilização. Apesar disso, não a escolhi porque o sistema funcionaria apenas via navegador na internet e precisava de algo que pudesse levar para o ambiente de estudo, o qual nem sempre teria um desktop ou notebook disponível. Além desse ponto,

43 Alguns exemplos de aplicações encontradas são: MyTractice (https://goo.gl/P7NYkw), Musicians Practice Log (https://goo.gl/oaVRY6) e Music Journal (https://goo.gl/L5SPsd), para smartphones.

44 Disponível em: https://musictoolsuite.ca/cadenza/ 
o processamento e revisão das informações sobre o estudo ao longo das semanas seria mais difícil. Sendo assim, as ferramentas escolhidas foram as seguintes:

- Diário de estudo (usado no planejamento, relatórios de estudo e avaliação semanal): para esta função foram utilizadas tabelas no aplicativo Google Planilhas, que me permitia incluir, organizar, relacionar e analisar as atividades realizadas - tanto em aplicativo pelo smartphone quanto pelo computador.

- Gerenciamento do tempo: além do relógio para monitorar a hora de prática e os intervalos, utilizei o aplicativo Toggl Time Tracker para registrar o tempo gasto nas atividades. Eventualmente este aplicativo poderia servir como um cronômetro, para não exceder o tempo dedicado a uma mesma tarefa, além de permitir visualizar um panorama das atividades realizadas. Eventualmente a função de timer do relógio (contador regressivo) poderia ser utilizado para reforçar a atenção, caso percebesse muita distração na sessão de estudo. Por exemplo, poderia marcar cinco minutos de trabalho em um aspecto. Ao final desse tempo, reviso se trabalhei exatamente o que pretendia ou se perdi o foco e poderia relembrar as metas da sessão de estudo, como pretendo proceder, etc.

- Gravação (áudio e vídeo): utilizada como suporte para ouvir o resultado do trabalho no repertório e identificar falhas ou incoerências não percebidas durante a execução. 0 registro de algumas sessões de estudo poderia ajudar a observar maus hábitos ou aspectos falhos no decorrer da atividade que fogem à atenção durante a prática. A revisão desse material faz parte também do estudo, e, portanto, numa situação real, deve ser incluída no tempo de trabalho e compatível com o tempo disponível.

As estratégias utilizadas nessa etapa relacionam-se com as etapas de planejamento, execução e avaliação da autorregulação da aprendizagem, conforme discutido anteriormente. Além disso, pode-se estabelecer também uma relação entre essas estratégias e os 6 aspectos que influenciam a autorregulação em música, conforme proposto por Mcpherson e Zimmerman (2011):

- Motivo: a escolha de repertório baseada em interesse pessoal, o agendamento de compromissos, a escolha de objetivos de curto/médio/longo prazo; 
- Método: o planejamento e organização do estudo, a seleção de estratégias, o uso de diário de estudos, uso do relógio/cronômetro para controle do tempo e do foco na atividade;

- Comportamento: A manutenção da atenção e concentração através do estabelecimento de metas claras, uso de estratégias de ensaio, relatórios e gravações como feedback, autoavaliação através da reflexão diária e semanal;

- Tempo: o controle e administração do tempo disponível para as tarefas;

- Ambiente de estudo: eliminação de distrações (internet, telefone), manter ferramentas sempre disponíveis (partituras, lápis, lixas, metrônomo, diários de estudo, etc);

- Fatores Sociais: a procura de orientação de professor e colegas, escuta de gravações de outros intérpretes, procura de informações sobre o repertório;

Alguns desses procedimentos estão fortemente ligados entre si, e, portanto, essa categorização é apenas para ilustração das estratégias autorreguladoras que entraram no processo de estudo desta etapa prática. Importante dizer que algumas estratégias já faziam parte do meu estudo, em maior ou menor grau. No entanto, através da avaliação e reflexão inicial, foi possível identificar algumas possíveis deficiências.

\subsection{Avaliação e Planejamento inicial}

Observando os resultados dos questionários pude extrair alguns aspectos que mereciam mais atenção na rotina de estudos pessoal. Analisando essas informações foi possível evidenciar os seguintes elementos que poderia desenvolver:

- Metas: escolher objetivos mais claros, tanto para as sessões de estudo quanto para as metas de longo prazo; buscar metas que tragam mais desafio; priorizar aspectos interpretativos e expressivos nas metas;

- Estratégias: observar quais estratégias que utilizo, verificar em qual contexto se adequam e ampliar esse conhecimento; administrar o uso da repetição no estudo; rever as estratégias para subir andamento;

- Concentração e atenção: Utilizar estratégias para eliminar distrações e administrar pensamentos extramusicais durante o estudo; 
- Feedback e avaliação: Utilizar mais o recurso da gravação para monitoramento e avaliação, procurando avaliar objetivamente o estudo e o progresso em direção às metas estabelecidas.

- Monitoramento: Avaliar de maneira mais objetiva o estudo e o progresso em direção às metas estabelecidas.

- Praticar leitura, ampliar conhecimento musical, ouvir mais gravações e/ou assistir concertos, buscar mais informações externas (consultando materiais, colegas ou professores).

- Revisão de repertório antigo.

Destaco que em outros semestres durante o mestrado realizei alguns períodos de estudo de forma planejada, utilizando um diário de estudos para registrar o que foi feito e anotar observações sobre o processo. Apesar de permitir observar o progresso e também algumas possíveis lacunas na prática, nem sempre conseguia identificar o que precisava modificar para atingir as metas, o que pode indicar falta de conhecimento sobre as estratégias e seu uso. Durante esses períodos, percebi também era necessária grande dose de disciplina e motivação para sustentar por um longo tempo o planejamento e/ou diário de estudos detalhado ${ }^{45}$ e com frequência, a rotina de planejamento era interrompida por uma ou mais semanas, principalmente pela influência de fatores externos (compromissos, atividades acadêmicas, etc) ${ }^{46}$.

Apesar dessas dificuldades, para efeitos desse estudo, procurei realizar o planejamento e os relatórios de forma bem detalhada, a fim de evidenciar de maneira mais clara possível como foi o processo de estudo. É importante considerar neste caso que o ato de planejar em si toma parte do tempo disponível, portanto foi considerado parte integrante do estudo individual. Em uma situação real esse tempo deve ser compatível com a rotina e as necessidades do músico.

45 Isso é algo igualmente presente na fala dos sujeitos no trabalho de intervenção de Hatfield (2016), que se utilizava do diário de estudos, dentre outros recursos, para promover o comportamento autorregulador e estratégias de estudo.

46 A dificuldade dos estudantes de música em seguir uma rotina de estudos planejada é abordada em pesquisa de ROJAS, J.; SPRINGER, G. An Exploratory Study of Musicians' Self-Efficacy to Maintain Practice Schedules. Bulletin of the Council for Research in Music Education, No. 199. 2014, p. 39-52. 


\section{- 0 programa estudado:}

A divisão do repertório estudado seguiu a proposta de Klickstein, que organiza de acordo com o desenvolvimento das músicas. Esta servia apenas como uma orientação geral e não funciona de modo tão exato, já que de acordo com a necessidade, obras do bloco de performance poderiam voltar a um trabalho de desenvolvimento, por exemplo. Em cada dia de estudo deveria haver um tempo dedicado a essas diferentes áreas, de modo que trabalho fique equilibrado.

As obras novas que foram escolhidas para estudo são de Camargo Guarnieri, as quais tive contato apenas através da escuta em recitais. As peças no grupo "Em desenvolvimento" são obras em que já fiz um trabalho inicial de leitura, compreensão e digitação, mas ainda precisam definir a interpretação, trabalho técnico, elevar andamento, trabalhar fluidez e memorizar. As peças que estão na categoria "Performance" são obras que já apresentei em público ou que estão mais aptas para isso, que precisam de revisão de aspectos interpretativos, manutenção técnica e prática da performance. Sendo assim, o repertório e as tarefas ficaram organizadas da seguinte forma:

- NOVAS: Camargo Guarnieri (Valsa-Chôro 1 e Ponteio);

- EM DESEnVolvimento: Manuel Ponce (Homenaje a Tárrega e Estudio); Bach (Suite VI-Allemande, Courante);

- PERFORMANCE: Bach (Suite VI - Preludio, Sarabanda, Gavota I e II, Giga); Manuel Ponce (Vespertina, Rondino); Abel Carlevaro (Estudo I - Homenagem a VillaLobos);

- TÉCNICA: Exercícios de mecânica básica (escalas, arpejos, ligados); técnicas necessárias para o repertório: Tremolo, velocidade de indicador e médio (speed burst), escalas com indicador e anelar; ornamentos (ME e MD); outros aspectos deficientes: traslado, alinhamento ME, e relaxamento ME;

- MUSICALIDADE: escuta atenta de interpretações do repertório estudado e obras correlatas (e.g. escutar versões da Suite VI e outras Suítes de Bach; conhecer outras obras de Camargo Guarnieri); observar uso do timbre e recursos expressivos em intérpretes de violão; praticar a leitura. 
Além da escolha do repertório, alguns compromissos foram estabelecidos: recital ao fim do período de estudo, gravações periódicas (das sessões de estudo e performances das obras), tocar para outras pessoas (professor e colegas).

\section{- A estrutura do diário de estudo:}

Para a estrutura do planejamento e relatórios, foram usados dois tipos de tabelas:

a) uma tabela geral para o planejamento/avaliação,

b) uma tabela separada para cada música.

Através do aplicativo de controle do tempo era possível monitorar dois aspectos: 1) quais peças estudei de fato em cada dia e 2) quanto tempo durou cada sessão de estudo (o que me fornecia também uma estimativa geral do tempo dedicado ao estudo).

A tabela geral (Figura 2) era organizada semanalmente com o seguinte:

- Metas da Semana (que deveriam estar alinhadas com as metas de longo prazo);

- Organização do trabalho semanal: distribuição do estudo do repertório ao longo da semana de forma equilibrada - plano esse que não era exatamente uma regra fixa, mas uma referência para o trabalho que deveria ser feito;

- Registros ou impressões gerais sobre o estudo;

- Avaliação semanal.

Figura 2: Modelo usado para o plano de estudos semanal

\begin{tabular}{|l|c|c|c|c|c|c|}
\hline & $\begin{array}{c}\text { Plan+Aval } \\
\text { Semanal }\end{array}$ & Semana X & dd/mm/aaaa & & \\
\hline \multicolumn{1}{|c|}{ Seg } & Terça & Quarta & Quinta & Sexta & Sábado & Domingo \\
\hline Aquecimento & & & & Revisão & Avaliação \\
\hline Técnica & & & & Extras & Planejamento \\
\hline Obra 1 & & & & Descanso \\
\hline Obra 2 & & & & \\
\hline Obra 3 & & & & \\
\hline & & & & \\
\hline Metas-semana & Impressões diárias & Avaliação & & \\
\hline & & & & \\
\hline & & & \\
\hline
\end{tabular}

Fonte: elaborada pelo autor. 
A tabela individual (Figura 3) de cada música servia para registrar o seguinte:

- Data em que estudei;

- Metas: o objetivo daquela sessão de estudo, o que queria/precisava trabalhar, desenvolver ou resolver;

- Estratégias: abordagem que pretendia utilizar;

- Resultados: registro do que foi realizado de fato, impressões sobre aquela sessão de estudo, ideias que surgiram, dificuldades percebidas;

- Pendências gerais: lista geral onde registrava o que faltava resolver na música, trechos críticos ou problemas recorrentes que necessitavam estudo, etc.

Figura 3: Modelo usado como diário de estudo para cada obra

\begin{tabular}{|l|l|l|l|l|l|}
\hline \multicolumn{5}{|c|}{ Obra XYZ } & \multirow{2}{*}{ Pendências } \\
\hline Data & Metas & Estratégia & Resultados/Avaliação & Anexos & Duração (min) \\
\hline & & & & \\
\hline & & & & \\
\hline & & & & \\
\hline
\end{tabular}

Fonte: elaborada pelo autor

\subsection{Resultados e discussão sobre o processo de estudo}

Com os registros realizados foi possível extrair alguns dados gerais sobre esta experiência, como a quantidade de sessões de estudo, tempo gasto total, impressões sobre a prática, dificuldades encontradas, onde percebi resultados positivos e o que não funcionou como esperava.

Nas figuras 4, 5 e 6 os gráficos mostram respectivamente a quantidade de sessões de estudo realizadas para cada música, o tempo dedicado ao trabalho em cada uma das obras e a estimativa de tempo semanal/geral (gerada automaticamente pelo aplicativo ToggI). Através desses dados era possível observar se as prioridades no estudo 
receberam de fato mais atenção, se negligenciei o preparo de algumas obras e se o tempo de estudo estava adequado à quantidade de atividades que precisava desenvolver. Ainda assim, se uma obra recebesse atenção suficiente e isto não trouxesse desenvolvimento, poderia indicar que as estratégias utilizadas não estavam funcionando, que o estudo foi improdutivo, que havia alguma lacuna na compreensão do trabalho, que o prazo para desenvolver a obra precisava ser maior ou que talvez o repertório estivesse em um nível acima do que eu seria capaz de tocar.

Figura 4: Quantidade de sessões de estudo (01/02 a 24/04)

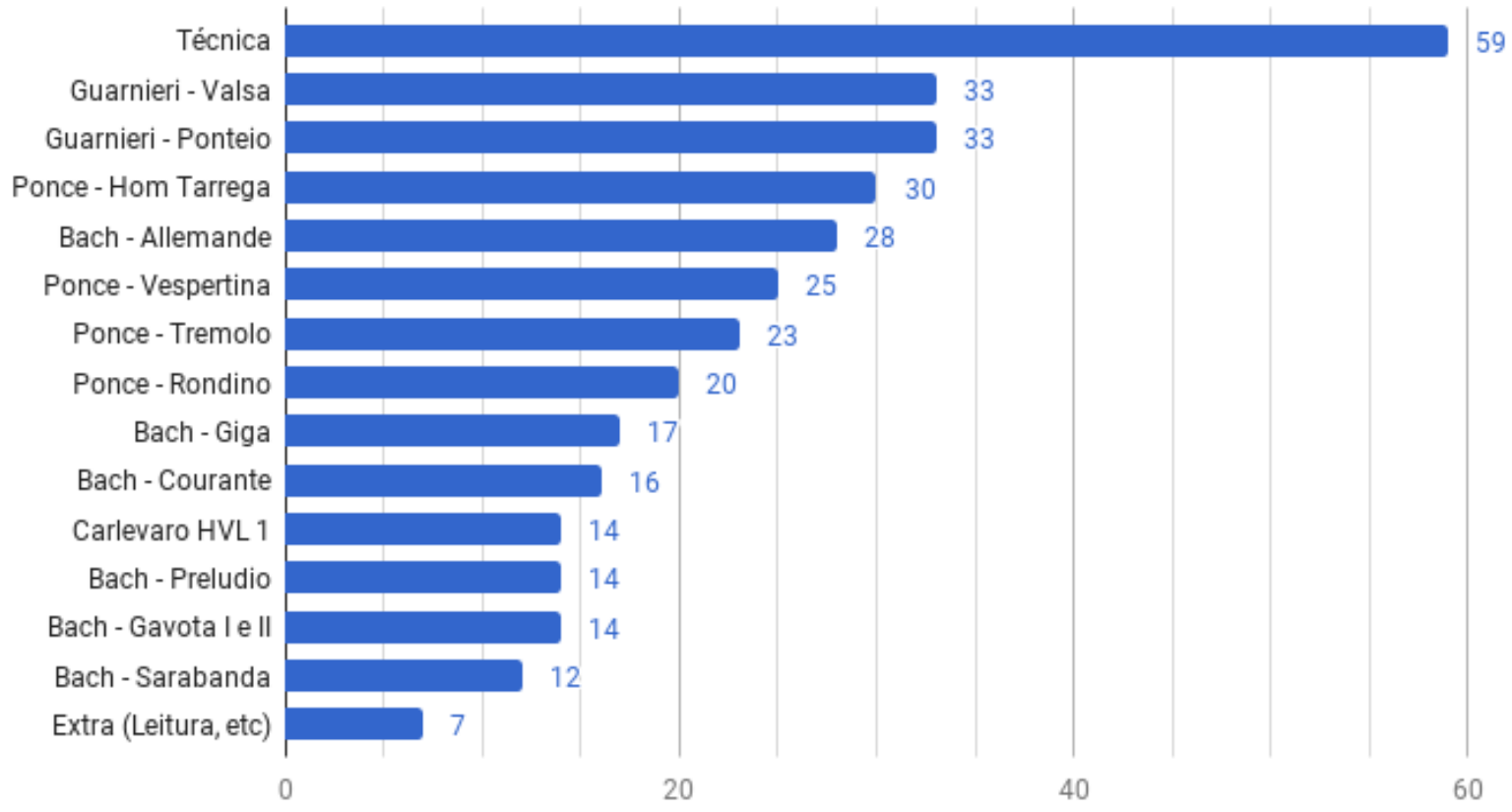

Fonte: elaborada pelo autor 
Figura 5: Tempo dedicado a cada tarefa

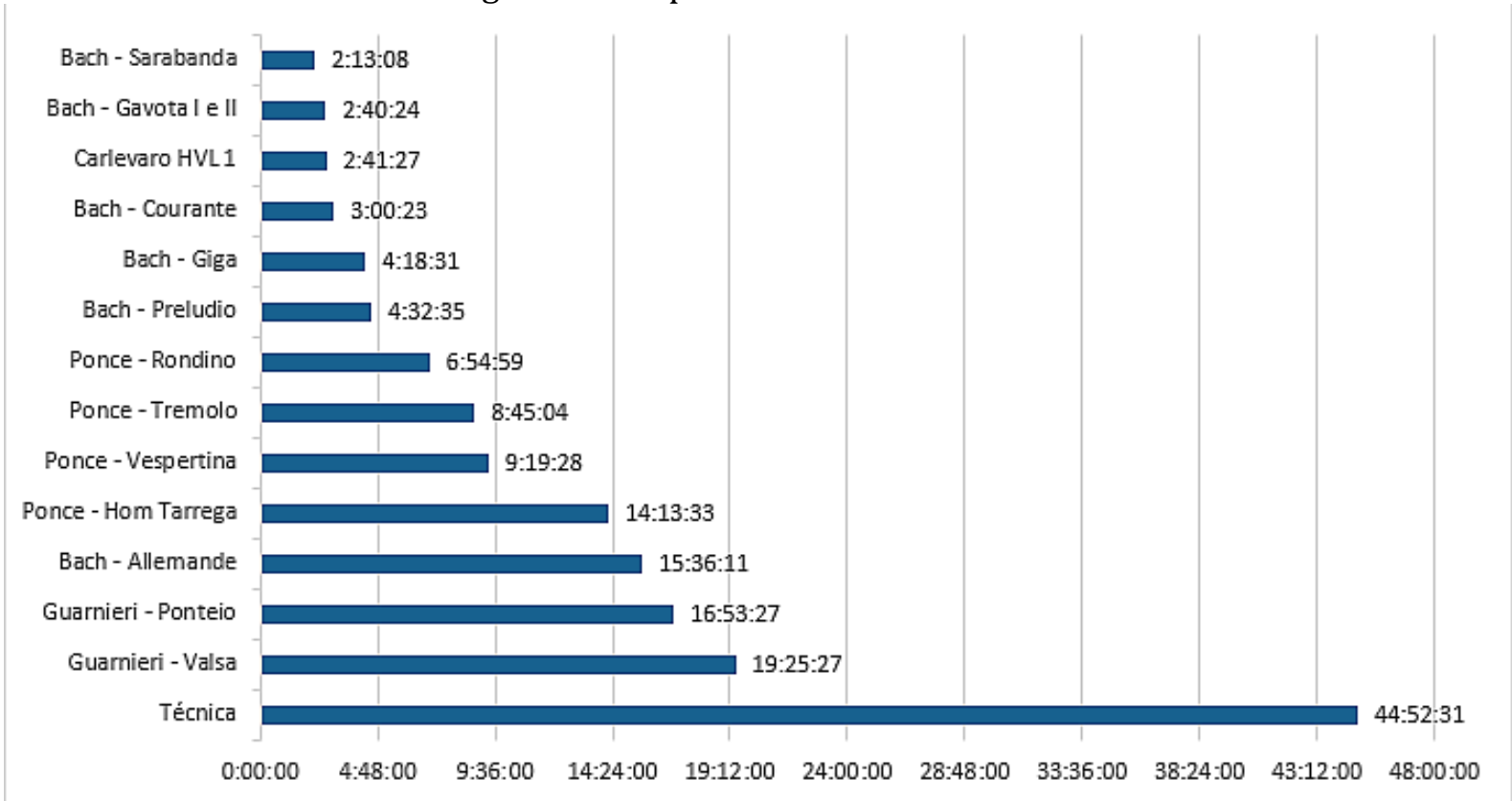

Fonte: Elaborada pelo autor.

O total em sessões de estudo (155 horas e 27 minutos) e a quantidade de tempo de trabalho em cada semana estão na figura 6. Esta é apenas uma estimativa através do aplicativo Toggl, onde foi registrado o tempo apenas durante o trabalho em cada atividade. Não estão inclusos o tempo de intervalo entre as sessões, o tempo gasto com aquecimento, planejamento, relatórios, revisão das gravações, o que aumentaria em aproximadamente 1 hora o tempo dedicado à atividade diariamente, e em média 6 horas para cada semana. Consequentemente, elevaria em 72 horas o total, resultando em uma estimativa final de 227 horas e 27 minutos. 
Figura 6: Tempo gasto por semana com as sessões de estudo e estimativa total do período

\title{
Summary report
}

(1) toggl

\author{
2017-02-01 - 2017-04-24
}

Total $155 \mathrm{~h} 27 \mathrm{~min}$

Bach - Allemande, Bach - Courante, Bach - Gavota I e II and 11 more selected as projects

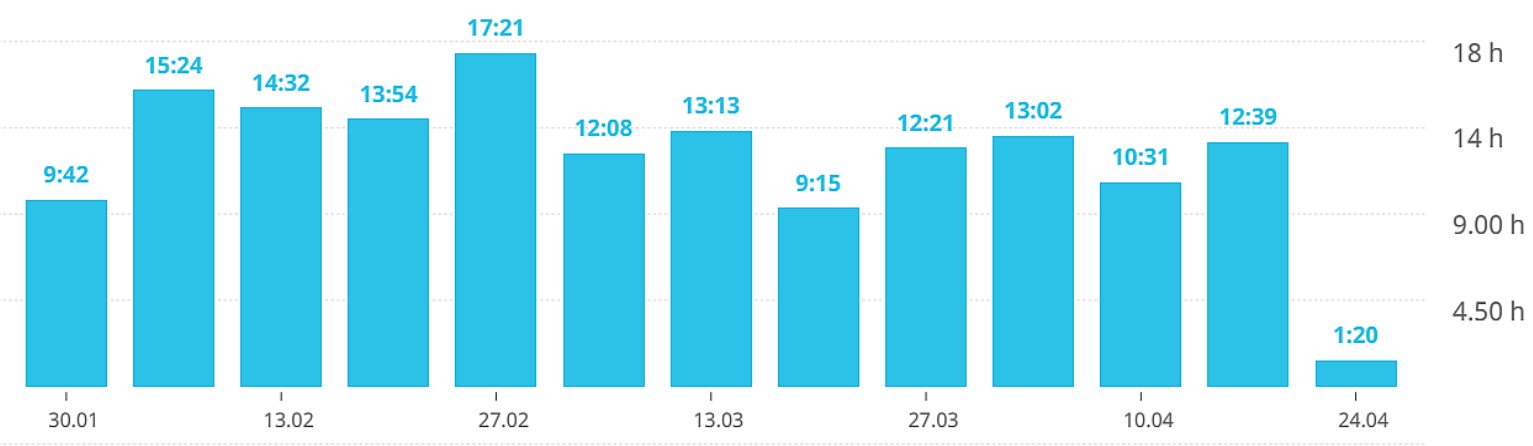

Fonte: elaborada pelo autor através do aplicativo Toggl Time Tracker.

Nas primeiras semanas desta etapa prática a categorização das obras estudadas passou por algumas modificações. Algumas obras que julgava estar em nível mais apto para performance na verdade não estavam bem resolvidas (Ex: Vespertina do Ponce). Da mesma forma, outras que coloquei na categoria "Desenvolvendo" já estavam mais prontas (Ex: Courante do Bach). Isto mostra que essas categorias são apenas um referencial flexível e indica também que minha avaliação inicial das obras não foi tão precisa.

A distribuição semanal das tarefas e o trabalho diário procurava seguir alguns critérios: era importante estudar todos os dias ao menos uma obra de cada grupo (novas, desenvolvendo e performance), além do trabalho técnico. A prioridade era estudar diariamente as músicas novas, que exigiam mais atenção e demandava tempo. Estas deveriam ser distribuídas de forma alternada ao longo dos dias. As outras obras eram também inseridas na semana de forma equilibrada (e.g. evitava estudar duas peças com tremolo no mesmo dia, para alternar a demanda técnica), de modo que ao término da semana cada peça do repertório fosse estudada entre 2 a 3 vezes. 0 início do estudo contava com algum breve aquecimento, revisão das tarefas escolhidas e as pendências a 
desenvolver. As sessões eram distribuídas com intervalos de 10 minutos, em média, ou realizadas em partes diferentes do dia (e.g. manhã e noite).

Figura 7: Comparação entre o planejamento e a execução na 5aㅗ semana de estudos.

\begin{tabular}{|c|c|c|c|c|c|c|}
\hline & \multicolumn{2}{|c|}{ PLANEJADO } & \multirow{2}{*}{$\begin{array}{c}\text { Semana } 5 \\
\text { Quinta }\end{array}$} & \multirow{2}{*}{$\begin{array}{c}27 / 02 / 2017 \\
\text { Sexta }\end{array}$} & \multirow[b]{2}{*}{ Sábado } & \multirow[b]{2}{*}{ Domingo } \\
\hline Segunda & Terça & Quarta & & & & \\
\hline Técnica & Técnica & Técnica & Técnica & Técnica & Técnica & Leitura \\
\hline $\begin{array}{l}\text { Guarnieri - } \\
\text { Valsa }\end{array}$ & $\begin{array}{c}\text { Guarnieri - } \\
\text { Ponteio }\end{array}$ & $\begin{array}{l}\text { Guarnieri - } \\
\text { Valsa }\end{array}$ & $\begin{array}{c}\text { Guarnieri - } \\
\text { Ponteio }\end{array}$ & $\begin{array}{l}\text { Guarnieri - } \\
\text { Valsa }\end{array}$ & $\begin{array}{c}\text { Guarnieri - } \\
\text { Ponteio }\end{array}$ & Gravação \\
\hline $\begin{array}{c}\text { Bach - } \\
\text { Allemande }\end{array}$ & $\begin{array}{c}\text { Ponce - Hom } \\
\text { Tarrega }\end{array}$ & $\begin{array}{c}\text { Bach - } \\
\text { Allemande }\end{array}$ & $\begin{array}{c}\text { Ponce - Hom } \\
\text { Tarrega }\end{array}$ & $\begin{array}{c}\text { Bach - } \\
\text { Allemande }\end{array}$ & $\begin{array}{c}\text { Ponce - Hom } \\
\text { Tarrega }\end{array}$ & \\
\hline $\begin{array}{l}\text { Ponce - } \\
\text { Tremolo }\end{array}$ & $\begin{array}{c}\text { Ponce - } \\
\text { Vespertina }\end{array}$ & $\begin{array}{l}\text { Ponce - } \\
\text { Tremolo }\end{array}$ & $\begin{array}{l}\text { Ponce - } \\
\text { Vespertina }\end{array}$ & $\begin{array}{l}\text { Ponce - } \\
\text { Tremolo }\end{array}$ & $\begin{array}{l}\text { Bach - } \\
\text { Courante }\end{array}$ & $\begin{array}{l}\text { Aval + } \\
\text { Planej }\end{array}$ \\
\hline $\begin{array}{c}\text { Bach - } \\
\text { Sarabanda }\end{array}$ & $\begin{array}{l}\text { Ponce - } \\
\text { Rondino }\end{array}$ & Bach - Giga & $\begin{array}{l}\text { Ponce - } \\
\text { Rondino }\end{array}$ & $\begin{array}{l}\text { Bach - } \\
\text { Preludio }\end{array}$ & $\begin{array}{c}\text { Bach - } \\
\text { Sarabanda }\end{array}$ & \\
\hline \multirow[t]{2}{*}{ Bach - Giga } & $\begin{array}{l}\text { Bach - } \\
\text { Preludio }\end{array}$ & $\begin{array}{c}\text { Bach - } \\
\text { Gavota I e II }\end{array}$ & $\begin{array}{l}\text { Bach - } \\
\text { Courante }\end{array}$ & Bach - Giga & $\begin{array}{c}\text { Carlevaro } \\
\text { HVL } 1\end{array}$ & \\
\hline & \multicolumn{3}{|c|}{ REALIZADO } & & & \\
\hline Segunda & Terça & Quarta & Quinta & Sexta & Sábado & Domingo \\
\hline Técnica & Técnica & Técnica & & Técnica & Técnica & \\
\hline \multirow[t]{2}{*}{$\begin{array}{c}\text { Guarnieri - } \\
\text { Valsa }\end{array}$} & $\begin{array}{l}\text { Guarnieri - } \\
\text { Ponteio }\end{array}$ & $\begin{array}{l}\text { Guarnieri - } \\
\text { Valsa }\end{array}$ & $\begin{array}{c}\text { Guarnieri - } \\
\text { Ponteio }\end{array}$ & $\begin{array}{l}\text { Guarnieri - } \\
\text { Valsa }\end{array}$ & $\begin{array}{l}\text { Guarnieri - } \\
\text { Ponteio }\end{array}$ & \\
\hline & $\begin{array}{c}\text { Ponce - Hom } \\
\text { Tarrega }\end{array}$ & & $\begin{array}{c}\text { Ponce - Hom } \\
\text { Tarrega }\end{array}$ & & $\begin{array}{c}\text { Ponce - Hom } \\
\text { Tarrega }\end{array}$ & \\
\hline \multirow[t]{2}{*}{$\begin{array}{l}\text { Ponce - } \\
\text { Tremolo }\end{array}$} & $\begin{array}{l}\text { Ponce - } \\
\text { Vespertina }\end{array}$ & $\begin{array}{l}\text { Ponce - } \\
\text { Tremolo }\end{array}$ & $\begin{array}{l}\text { Ponce - } \\
\text { Vespertina }\end{array}$ & $\begin{array}{l}\text { Ponce - } \\
\text { Tremolo }\end{array}$ & $\begin{array}{l}\text { Bach - } \\
\text { Courante }\end{array}$ & $\begin{array}{l}\text { Aval + } \\
\text { Planej }\end{array}$ \\
\hline & $\begin{array}{l}\text { Ponce - } \\
\text { Rondino }\end{array}$ & & $\begin{array}{l}\text { Ponce - } \\
\text { Rondino }\end{array}$ & & $\begin{array}{c}\text { Bach - } \\
\text { Sarabanda }\end{array}$ & \\
\hline \multirow[t]{3}{*}{ Bach - Giga } & $\begin{array}{l}\text { Bach - } \\
\text { Preludio }\end{array}$ & & $\begin{array}{l}\text { Bach - } \\
\text { Courante }\end{array}$ & Bach - Giga & $\begin{array}{c}\text { Carlevaro } \\
\text { HVL } 1\end{array}$ & \\
\hline & $\begin{array}{c}\text { Bach - } \\
\text { Allemande }\end{array}$ & & & & $\begin{array}{c}\text { Bach - } \\
\text { Allemande }\end{array}$ & \\
\hline & & & & & $\begin{array}{c}\text { Bach - } \\
\text { Gavota I e II }\end{array}$ & \\
\hline
\end{tabular}

Fonte: Elaborada pelo autor.

Nem sempre era possível seguir essas regras mas era importante ter o planejamento como uma referência para o trabalho. Na figura 7 há duas tabelas onde constam o planejamento da semana 5 e abaixo, o que foi realmente trabalhado nessa semana. Como se vê nesse exemplo, em geral, muitas tarefas planejadas eram mantidas, 
mas sempre havia alterações. Alguns dias eram menos produtivos, outros conseguia trabalhar um pouco mais e isto era influenciado por diversos fatores, muitos dos quais externos à atividade musical. Em uma situação em que a execução do plano começa a se afastar muito do planejamento é importante avaliar o caso e procurar identificar os motivos: as tarefas demandam muito mais do que se esperava? Há elementos que estão atrapalhando a concentração? Há dúvidas com relação ao que fazer nas tarefas? A motivação para o trabalho está baixa? As metas estabelecidas não apresentam desafio/estímulo? O horário do estudo está inadequado? Ao revisar esses elementos, é necessário adaptar o planejamento e encontrar um equilíbrio melhor entre desafio, necessidades e possibilidade de execução.

Ao longo do processo, depois que as obras novas já estavam mais definidas passei a organizar o repertório de forma diferente: apenas uma lista sequencial que partia das obras das menos resolvidas até as mais aptas para a performance, lista esta que era revisada semanalmente. Na Figura 8 é possível comparar as duas abordagens de organização do repertório.

Figura 8: Distribuição do repertório na $1^{\mathrm{a}}$ semana e na $11^{\mathrm{a}}$, respectivamente

\begin{tabular}{|c|c|c|c|c|}
\hline \multicolumn{2}{|c|}{ Semana 1} & \multicolumn{3}{|c|}{ Semana 11} \\
\hline \multicolumn{2}{|c|}{ Tarefas } & \multicolumn{3}{|c|}{ Tarefas } \\
\hline \multirow{2}{*}{ Novas } & Guarnieri - Valsa & \multirow{6}{*}{ Desenvolvendo } & Ponce - Tremolo & Menos prontas \\
\hline & Guarnieri - Ponteio & & Guarnieri - Ponteio & $<<<<<$ \\
\hline \multirow{5}{*}{ Desenvolvendo } & Bach - Allemande & & Ponce - Hom Tarrega & $<<<<$ \\
\hline & Bach - Courante & & Guarnieri - Valsa & $\ll<$ \\
\hline & Ponce - Hom Tarrega & & Bach - Allemande & $\ll$ \\
\hline & Ponce - Tremolo & & Ponce - Vespertina & $<$ \\
\hline & Carlevaro HVL 1 & \multirow{7}{*}{ Performance } & Bach - Preludio & $>$ \\
\hline \multirow{6}{*}{ Performance } & Ponce - Vespertina & & Carlevaro HVL 1 & $\gg$ \\
\hline & Ponce - Rondino & & Ponce - Rondino & $\gg \gg$ \\
\hline & Bach - Preludio & & Bach-Courante & $\gg \gg>$ \\
\hline & Bach - Sarabanda & & Bach - Giga & $\gg \gg>>$ \\
\hline & Bach - Gavota I e II & & Bach - Gavota I e II & $\gg \gg \gg>$ \\
\hline & Bach - Giga & & Bach - Sarabanda & Mais Prontas \\
\hline
\end{tabular}

Fonte: Elaborada pelo autor. 
Na abordagem das peças novas (Valsa-Choro 1 e Ponteio de Guarnieri) procurei me basear nas informações levantadas da literatura sobre as etapas na preparação de uma obra nova (Provost, Ryan e Klickstein apresentam informações a respeito discutido no capítulo 3 do trabalho). Dessa forma, o trabalho iniciou com maior ênfase na compreensão musical, incluindo a leitura (com ou sem o violão), seguido pela digitação de ambas as mãos. Essa fase de leitura foi bem delimitada para não perder o foco no estudo, de forma que as sessões de estudo tinham como metas "ler até compasso X", ou "leitura da página 2". Após realizar essa compreensão e a digitação inicial da obra, os objetivos eram resolver trechos mecanicamente mais complexos, criar unidade nas frases e conectar as partes (com andamento mais lento que o da performance), para depois apurar os aspectos expressivos e a coerência geral. Já que uma das metas gerais do estudo era enfatizar o trabalho dos elementos expressivos, procurei desde o início montar as frases e as partes buscando um sentido musical. Conforme o estudo avançava, algumas escolhas iniciais foram revisadas, como o fraseado e a digitação.

Buscar informações além da partitura foi fundamental, dado que tive pouco ou nenhum contato com essas peças e também com as obras de Camargo Guarnieri. Portanto, realizei a leitura de textos sobre as peças, informações sobre o autor, escuta de gravações disponíveis, além da consulta ao orientador em algumas aulas.

0 registro do que realizei no estudo servia para poder rever o que fiz, observar os resultados, analisar se estava de acordo com o que planejei e também funcionava como uma medida da concentração e disposição naquele dia. Anotar o que foi feito permitia retomar o estudo da obra em outro dia tendo uma noção mais exata do que estava trabalhando ou o que estava pendente, ajudando a equilibrar o estudo da obra como um todo. Na figura 9 há um exemplo mostrando a utilização do diário de estudo. ${ }^{47}$

47 Nos anexos constam excertos do diário de estudo de obras inseridas no grupo "Em desenvolvimento" e "Performance". 
Figura 9: Excerto do diário de estudo da Valsa-Choro 1 (Camargo Guarnieri)

\begin{tabular}{|c|c|c|c|}
\hline \multicolumn{4}{|c|}{ Guarnieri - Valsa-Choro } \\
\hline Data & Metas & Estratégia & Resultados/Avaliação \\
\hline 01/02/2017 & $\begin{array}{l}\text { Compreensão (forma, frases, } \\
\text { harmonia, o que destacar), } \\
\text { leitura inicial, identificar } \\
\text { dificuldades, digitação }\end{array}$ & $\begin{array}{l}\text { leitura s/c/ } \\
\text { violão, estudo } \\
\text { lento, Ler e ouvir } \\
\text { Guarnieri }\end{array}$ & $\begin{array}{l}\text { Li parte A, anotei digitações, toquei sem } \\
\text { preocupação com andamento; filmei um trecho. } \\
\text { Preciso dar atenção aos elementos de expressão } \\
\text { (como construir o discurso, agogica, dinâmica e } \\
\text { timbres). Parte B tem muitas harmonias } \\
\text { diferentes. checar outra edição. }\end{array}$ \\
\hline 03/02/2017 & $\begin{array}{l}\text { 2a pág - Compreensão (forma, } \\
\text { frases, harmonia, o que } \\
\text { destacar), leitura inicial, } \\
\text { identificar dificuldades, } \\
\text { digitação }\end{array}$ & $\begin{array}{l}\text { leitura s/ c/ } \\
\text { violão, estudo } \\
\text { lento, Ler e ouvir } \\
\text { Guarnieri }\end{array}$ & $\begin{array}{l}\text { 2a parte tem coisas mais difíceis de ME; verificar } \\
\text { dúvida na edição. Mais difícil de concentrar hoje } \\
\text { (problema externo). Lembre-se: mapear antes a } \\
\text { peça, ler vozes, harmonia, não precisa definir } \\
\text { digitação de cara. Dica: para estratégia pode } \\
\text { estipular limites, até que compasso ler }\end{array}$ \\
\hline 05/02/2017 & $\begin{array}{l}\text { 3a pág - Compreensão (forma, } \\
\text { frases, harmonia, o que } \\
\text { destacar), leitura inicial, } \\
\text { identificar dificuldades, } \\
\text { digitação }\end{array}$ & idem & $\begin{array}{l}\text { poderia ter tocado menos tempo. Definir mapa } \\
\text { dinâmico e contrastes. Leitura está completa, } \\
\text { agora ater-se a detalhes mecanicos pra resolver } \\
\text { digitação }\end{array}$ \\
\hline $07 / 02 / 2017$ & $\begin{array}{l}\text { Revisão geral, checar trechos } \\
\text { problema para digitação }\end{array}$ & $\begin{array}{l}\text { seções, testar } \\
\text { digitações }\end{array}$ & $\begin{array}{l}\text { revisão, ainda gastei tempo tocando, mas redefini } \\
\text { algumas digitações que não agradavam }\end{array}$ \\
\hline
\end{tabular}

Fonte: Elaborada pelo autor.

A avaliação e reflexão sobre o próprio estudo ajudou reconhecer dificuldades, as quais exigiam soluções diferentes ou alterações no planejamento. Em algumas peças isto foi fundamental para perceber os problemas no processo de estudo e mudar a abordagem na preparação destas obras.

Este foi o caso da Homenaje a Tárrega de Ponce. Após algumas sessões, percebi que o trabalho não estava rendendo, havia dificuldade em estabelecer metas claras e algumas sessões ficavam sem foco (como é possível ver nos anexos com trechos em vídeo das sessões de estudo). Ao analisar o que estava fazendo ao longo das sessões de estudo, notei que deixei de resolver detalhes importantes nas etapas básicas de preparação da obra. Ao retornar ao processo de compreensão da forma, fraseado, elementos musicais e definir mais atentamente as digitações das mãos, o estudo ficou mais objetivo e a realização musical mais coerente.

A Allemande de Bach passou por problemas semelhantes. No caso, havia ainda a necessidade de se definir a transcrição, que estava em aberto. Por consequência, não havia ainda partitura definida, o que dificultava anotar digitações, ideias, memorizar e também definir metas claras para o estudo. Foi necessário definir uma versão da transcrição, escrever a partitura limpa e reiniciar o processo de estudo. 
O uso de gravações audiovisuais como registro no estudo foi de grande ajuda no processo, já que permitia observar detalhes não percebidos durante a prática. Por exemplo: problemas no fraseado, legato que não saía como esperava, mudança no andamento em partes musicalmente mais tensas.

Como exemplo do uso das gravações para auxiliar no estudo, é possível destacar algumas situações: na obra Homenaje a Tárrega, ao ouvir a gravação realizada, pude perceber mau controle do andamento em alguns trechos ${ }^{48}$; no Estudo de tremolo do Ponce pude observar falhas na disposição da mão esquerda em uma passagem que errava com frequência (percebi através de registro em vídeo); em gravação da ValsaChoro do Guarnieri percebi que acentuava indevidamente algumas notas no fraseado; na Gavota I e II de Bach utilizei a gravação de áudio para testar e observar opções de dinâmica.

Também foram registradas em video algumas sessões de estudo. Sem dúvida, o fato de filmar influenciava de alguma forma a prática, já que estimulava a atenção para estudar de maneira adequada, principalmente nos primeiros minutos das sessões e nas primeiras vezes em que isso foi feito. Apesar dessa limitação, o registro foi uma forma de interessante de observar as estratégias de estudo que utilizei e também evidenciar alguns problemas. Nos anexos em vídeo foram selecionados excertos para ilustrar não apenas as estratégias e os momentos bons, mas os aspectos improdutivos ou ineficientes: há momentos em que se nota falta de foco (em que estou distraído com problemas externos, trabalhando sem metas claras ou sem estratégias definidas); outros em que uso demasiado a repetição sem ter resolvido o problema em questão; ou ainda onde testo determinada passagem com andamento mais rápido sem ter trabalhado devidamente a coordenação. Nas sessões de estudo gravadas as obras trabalhadas foram Ponteio e Valsa-Choro 1 (Guarnieri), no Estudio de tremolo (Ponce) e na Allemande (Bach).

Ao observar os relatórios e vídeos foi possível observar o uso de algumas estratégias de ensaio mais frequentes. De forma geral, foram utilizadas:

- Estudo com/sem instrumento

48 Esta reflexão registrei nos diários de estudo: "Ouvi a gravação e havia flutuações de tempo ruins na página 1 e fim da página 6 - foi o que estudei nesta sessão. Pratiquei com e sem metrônomo, tocando só melodia ou tudo junto". Comentário sobre a 9a sessão de estudo, registro em 21/02. 
- Digitação de ambas as mãos, buscando equilíbrio entre exigências musicais e funcionalidade no instrumento;

- Trabalho a partir de seções, trechos curtos ou frases, que eram agregadas posteriormente;

- Resolução de problemas técnico-mecânicos;

- Estudo progressivo do andamento com metrônomo e alternância entre andamento lento e rápido em alguns trechos;

- Estudo das dinâmicas, fraseado, coerência entre as partes;

- Estudo mental no trabalho de revisão e memorização;

Além disso, especificamente na compreensão inicial das obras e em situações de dúvida sobre elementos expressivos e interpretativos, alguns procedimentos usados foram: tocar partes separadas (apenas harmonia, a linha melódica, os baixos ou vozes específicas) solfejar o ritmo, experimentar ideias (dinâmicas opostas, articulações diferentes, exagerar contrastes, etc). Em Homenaje a Tárrega, por exemplo, isto ajudou a compreender a métrica, as frases, e separar ideias contrastantes. No caso do Estudio do Ponce, o estudo da linha melódica sem o tremolo ajudou a compreender as frases com menor exigência das mãos.

Na resolução de problemas mecânicos algumas estratégias usadas foram: estudo lento e progressivo (para a coordenação), análise e compreensão dos movimentos envolvidos, revisão da digitação, estudo com ritmos diferentes do que está escrito (e.g. escala no Preludio de Bach, trechos críticos da Giga, tremolo no Estudo do Ponce e Ponteio do Guarnieri) e estudo de mãos separadas (e.g. tremolo para obras do Ponce e Guarnieri; arpejos e velocidade no Estudo 1 HVL do Carlevaro; acordes repetidos e ligados com dedos fixos na Homenaje à Tarrega; mão esquerda em sequências do Ponteio; oitavas no Rondino do Ponce).

Sobre o recital realizado ao fim desta etapa prática, de maneira geral, consegui tocar mais atento à intenção musical, que era um dos objetivos estabelecidos. Uma dificuldade que mais atrapalhou foi administrar a concentração e a atenção, que se desviava com frequência e gerou mais erros do que o comum (isto ocorreu também na passagem geral que fiz dias antes, a qual filmei e revisei). No entanto, como não estava 
nervoso, isto não abalou tanto a confiança e não piorou ao longo do recital. Pelo contrário, na metade do programa a concentração aumentou e já estava mais presente, consegui tocar mais atento, procurando seguir/ouvir internamente a música.

Acredito que o problema da concentração abalou muito mais a precisão técnica do que necessariamente a interpretação, que foi mais clara do que em outros concertos realizados durante mestrado. 0 que saiu impreciso, confuso ou incoerente no que tange a expressão e interpretação, talvez seja pela necessidade de refinamento e revisão no próprio estudo, pois o resultado está muito próximo do que estudei, como pude observar nas gravações. Assim sendo, com relação à expressividade o resultado foi mais positivo do que em outras apresentações, o que está alinhado com as metas estabelecidas previamente (enfatizar o trabalho expressivo). Ainda assim, esse é um trabalho que está em processo e os resultados surgem a longo prazo. Há ainda várias lacunas, por exemplo: o controle do timbre e das dinâmicas pode ser mais claro e variado $^{49}$, faltou preparo para a concentração na performance e a precisão técnica ficou abalada em situação de stress. Sabendo disso, é necessário maior cuidado e preparo com esses elementos nas próximas performances e devo incluir esse trabalho no planejamento do estudo.

Um elemento que contribuiu para a distração durante o concerto foi o ruído produzido pela vibração do apoio ergonômico. Já aconteceu pontualmente em outras ocasiões, mas neste recital foi bastante frequente e audível. Sempre é importante antecipar ao máximo as possíveis interferências na performance, mas quando há algo inesperado e que não se pode corrigir ou eliminar, é preciso, dentro do possível, não se deixar abalar e manter o foco nas músicas.

Esta reflexão/avaliação sobre o recital é limitada, obviamente, pela capacidade pessoal de escuta e julgamento crítico sobre uma determinada performance. Conforme o meu conhecimento musical e capacidade de avaliação se desenvolver, o feedback poderá ser mais preciso e consequentemente o estudo mais direcionado.

No programa não foi incluído o Estudio de tremolo do Ponce, pois percebi que precisaria mais tempo para atingir o andamento ideal com segurança e sem

49 Vale citar aqui que o instrumento que utilizo não oferece tantos recursos para o trabalho que estou tentando desenvolver, de modo que essas limitações incidem sobre vários aspectos do estudo e desenvolvimento musical. 
sobrecarregar a prática. As músicas novas (Guarnieri) tiveram bom resultado com relação ao que foi estudado - muitas ideias saíram da maneira que foram estudadas, apesar de algumas falhas pontuais. Outras nem tanto, como a Allemande, que não estava trabalhada o suficiente, já que defini a transcrição no meio do processo de estudo, retomei etapas básicas de digitação e ainda estava desenvolvendo os elementos expressivos. Apesar disso, não apenas ela, como toda a Suíte 6 de Bach teve melhor resultado musical do que nos últimos recitais.

Nos momentos que precederam o recital acabei me preocupando com diversos aspectos de organização (impressão do programa, montagem do palco, preparação do gravador e câmera) e me distraí conversando com outras pessoas enquanto estava no palco, algo que evito fazer quando vou tocar e creio ter influenciado negativamente a concentração. Apesar de reservado alguns minutos para afinar, aquecer e me concentrar em local isolado, poderia ter delegado algumas dessas funções e reservado mais tempo na preparação para a recital.

Com relação a ansiedade, não houve grandes dificuldades (como mãos trêmulas, suor e palpitação - efeitos que costumo sentir, em maior ou menor grau, em outras ocasiões). No entanto, como a concentração na atividade não estava boa, isso afetou a execução, gerando maior tensão e falhas na precisão. É necessário ainda melhorar a preparação para lidar com a tensão no palco, a qual sinto afetar diretamente a liberdade das mãos no instrumento. Neste sentido, poderia ter feito mais simulações antes do recital, tocado mais vezes para outras pessoas e me preparado mentalmente melhor para a situação.

No trabalho realizado ao longo dessas semanas percebi que a abordagem nas sessões de estudo estava mais consciente, com uma ideia mais clara do que precisava fazer e procurando evitar ao máximo a prática sem atenção (o que acontecia quando estava cansado ou preocupado com coisas externas ao estudo). Nem todas as sessões foram dessa forma e percebi em certa dificuldade em estabelecer as metas em algumas situações, principalmente quando era necessário desenvolver aspectos interpretativos. Para ajudar nesse ponto, eventualmente revisava as orientações dos autores violonistas sobre a preparação e refinamento do repertório (como as discutidas por Provost, Ryan e Klickstein). 
Sobre essa dificuldade em estabelecer de forma clara as estratégias de ensaio, acredito em dois possíveis motivos: 1) pode haver uma certa dificuldade pessoal em verbalizar ou deixar explícito o "como" fazer, já que exige reflexão sobre o processo de estudo, que pode incluir situações que são desenvolvidas de forma intuitiva/implícita; 2) o conhecimento em estratégias de ensaio adequadas para o trabalho pode ser ainda limitado, o que dificulta planejar de antemão a abordagem que será usada no estudo. Acredito que essa dificuldade ao longo do trabalho atrapalhou os resultados em algumas sessões, além de afetar a concentração, já que sem estabelecer objetivos e abordagens claras o foco de atenção pode ficar prejudicado. As gravações de algumas sessões de estudo que realizei (embora não sejam exatamente uma situação real, já que estava filmando) evidenciaram alguns desses momentos: há situações em que trabalhava com metas e abordagens bem definidas, em outras, havia incerteza e, portanto, o estudo rendia menos.

Encontrei também algumas dificuldades com relação ao planejamento e a avaliação semanal. Da maneira que foram concebidos inicialmente, esses procedimentos começaram a se tornar algo pesado e cansativo após algumas semanas, já que havia bastante rigor na hora de registrar o máximo possível de informações e na distribuição das tarefas ao longo da semana. Além disso, isto era realizado aos domingos, um dia que estabeleci como descanso da atividade, ainda que pudesse tocar ou ler qualquer outra coisa. Portanto, após evidenciar essa dificuldade, resolvi testar uma abordagem um pouco mais leve: em vez de planejar de uma só vez quais tarefas deveria trabalhar em cada dia da semana, organizei o repertório em uma lista que ia das obras menos aptas para as mais aptas para a performance (conforme exibido na figura 8) e estabeleci outras regras ${ }^{50}$ de trabalho diário para escolha do que praticar. Dessa forma, sentia mais liberdade para estudar e gastava menos tempo pensando na distribuição das tarefas. No entanto, exigia mais disciplina e controle diário para julgar o que estudar e não deixar de lado o que necessitava mais atenção.

Foi possível enfatizar o trabalho expressivo no estudo do repertório, algo que representava uma lacuna na minha prática (ponto que discutido inclusive na banca de qualificação), sendo um aspecto ainda em desenvolvimento e que demanda maior

50 Os critérios que orientavam a escolha do trabalho diário eram: escolher o que eu gostaria de estudar, priorizar as músicas menos desenvolvidas, não estudar as mesmas músicas em dias consecutivos (a não ser que fosse necessário) e alternar obras com diferentes demandas técnicas durante o dia. 
experiência. Esta é uma meta de longo prazo que foi estabelecida no plano de estudos, metas essas que eram sempre revisadas nas avaliações e que orientava o planejamento do trabalho semanal. Em muitas sessões de estudo estabeleci objetivos que se alinhavam com esse ponto, por exemplo: trabalhar conexões entre as frases, enfatizar contraste entre seções, trabalhar crescendo no trecho X, estudar rallentando do compasso $\mathrm{Y}$, entre outras. Quanto mais específico e claro os objetivos, maior era a concentração e o foco na sessão de estudo.

Sobre o preparo para a performance, acredito que poderia ter praticado e feito testes para o recital pelo menos duas semanas antes, e não apenas uma. Dessa forma, provavelmente teria mais tranquilidade e confiança, já que teria tempo de rever o que não estava funcionando e definir detalhes que ainda não estavam claros.

Um ponto interessante foi observar que quando estava tendo dificuldades para progredir em determinada música, tentar achar soluções apenas tocando a obra era o que menos ajudava. 0 trabalho progredia mais quando procurava rever a compreensão da música, solfejar as frases, tocar partes separadas, ouvir outros intérpretes tocando, procurar feedback de outras pessoas. Utilizando estratégias que iam além de simples execução o estudo se tornava mais interessante, mais produtivo, cansava menos fisicamente e o resultado musical era mais coerente. Algumas das sessões de estudo mais longas e produtivas que realizei envolveram não apenas a execução da música, mas formas diversas de trabalhar na compreensão e resolução de problemas.

Ao registrar todo o processo com os diários de estudo, anotando o que foi realizado, as dificuldades e soluções encontradas, pude ter uma dimensão real do quanto de fato estudei e o que estava sendo produzido. Isto permitia avaliar mais precisamente qual música está mais segura para performance, onde estão as lacunas, se algo está sendo negligenciando e que abordagens deram certo.

No entanto, para uma abordagem futura na rotina de estudos pessoal, modificaria alguns desses procedimentos. Por exemplo, o diário de estudo, que se mostrou uma ferramenta essencial, não seria usado para anotar todos os detalhes, como fiz para este trabalho, mas de forma mais simples, para registar quais as pendências principais, ideias, soluções e conclusões que tive nas sessões de estudo. Não marcaria também o tempo que gasto para estudar (apesar de controlar o tempo durante o estudo), mas apenas as músicas trabalhei nos dias da semana e a situação em que se encontram. 
Talvez também utilizasse os diários e planejamentos em papel, com as anotações e pendências das músicas junto à partitura, ou então poderia testar outro software de interface mais amigável que fosse direcionado para esse trabalho, como o Cadenza citado anteriormente.

Outro aspecto que alteraria seria a frequência do planejamento e da avaliação do processo de estudo. No meu caso, esses procedimentos seriam mais proveitosos e menos cansativos se realizados de forma mais espaçada (e.g. quinzenalmente). Apesar dessas dificuldades, a organização e reflexão na rotina diária, estabelecendo previamente o que se pretende fazer na sessão de estudo e como irá fazer parece ser fundamental em qualquer situação, ainda que não seja minuciosamente detalhado. 


\section{CONSIDERAÇÕES FINAIS}

O objetivo deste trabalho foi levantar estratégias para o estudo individual do violonista, relacionando as informações da pesquisa científica e da literatura voltada aos músicos. Com embasamento na autorregulação da aprendizagem, a intenção é que o estudante possa conhecer essas estratégias, refletir e buscar o que necessita para aperfeiçoar o seu próprio desenvolvimento musical.

Consultando a literatura voltada aos violonistas, discutida no capítulo 3 , foi possível encontrar algumas orientações valiosas no que diz respeito ao processo de estudo e aprendizagem. Nem todas essas informações, no entanto, tem correlato na pesquisa empírica. Dessa forma, para algumas delas não há uma análise profunda sobre seu funcionamento, em que situações são adequadas e se realmente são funcionais, muito embora tenha seu embasamento na experiência prática de seus autores. Isso ocorre porque a maior parte das pesquisas ainda conta apenas com referenciais teóricos de outras áreas do conhecimento, como a psicologia e neurociência, e não utiliza o material produzido pelos músicos teóricos da prática instrumental como tema ou parâmetros de investigação. No entanto, a aproximação entre a pesquisa empírica a prática musical pode ser muito benéfica. A pesquisa pode aproveitar informações inerentes à atividade musical que pesquisadores de outras áreas não conheceriam. Por outro lado, músicos e professores podem se beneficiar dos resultados científicos para rever suas práticas, eliminar hábitos ineficientes ou prejudiciais.

Não era objetivo dessa pesquisa encontrar fórmulas ou procedimentos que sirvam de maneira igual ao estudo musical de todos. Sendo assim, foi fundamental a referência da aprendizagem autorregulada (no capítulo 2), que considera o papel ativo do estudante em guiar o seu próprio estudo, refletindo e planejando sua prática de acordo com suas necessidades e possibilidades. Se há uma recomendação que serve a todos é justamente a importância de se desenvolva a autonomia no estudo para obter resultados positivos no aprendizado.

Quando se fala em desenvolver a autonomia não significa que o aprendiz que desenvolver a capacidade de autorregulação atingirá altos níveis de expertise, de maneira extremamente eficiente, produtiva e sem precisar de professor, orientação, ou 
qualquer ajuda. 0 que se ganha ao cultivar bons hábitos de estudo é que este músico poderá avaliar melhor sua situação, julgar de maneira mais objetiva o seu trabalho, buscar o desenvolvimento de suas habilidades de maneira estruturada e saber procurar ajuda quando necessário. Ou seja, a intenção com essa abordagem não é tornar o estudante um concertista no menor tempo possível, mas sim dar ferramentas para que ele saia do nível em que está para outro mais avançado, em diferentes aspectos da prática musical, de maneira consciente e objetiva.

Além disso, o mecanismo de regulação do comportamento inclui diversos aspectos que não estão totalmente ao controle direto do indivíduo, como é o caso das variáveis motivacionais e emocionais. A abordagem do conceito de autorregulação neste trabalho não buscava novas conclusões e aprofundamentos sobre a teoria, mas sim uma referência para estruturar as diferentes estratégias de estudo que colaboram no desenvolvimento e a autonomia da aprendizagem musical. Os trabalhos com discussão teórica, estudos de caso e pesquisa experimental sobre autorregulação em música ainda são poucos, recentes e ainda é necessário aprofundar a investigação sobre como se pode promover esse comportamento nos estudantes.

Como foi discutido no capítulo 2, o desenvolvimento da capacidade autorregulada ocorre de maneira gradativa de acordo com o desenvolvimento da expertise e prescinde de suporte social, principalmente em suas primeiras etapas. Esse suporte se dá através dos pais, colegas e os professores, sendo que este último tem um papel crucial na formação dos hábitos de estudo do aprendiz. Ao fornecer modelos adequados de como estudar, apresentar instruções claras nas aulas e incentivar a reflexão e participação ativa do aluno no seu aprendizado, o professor colabora para que o aluno desenvolva sua capacidade de regular o próprio aprendizado em direção às metas que estabelece para si. Formar músicos com boa capacidade crítica, criatividade, individualidade, que buscam os próprios caminhos é algo essencial para que a prática musical não seja apenas a reprodução de modelos já estabelecidos de interpretação e execução, mas que promova a pesquisa, a reflexão, a diversidade, o estabelecimento de novas relações e novas ideias.

$\mathrm{Na}$ atualidade, a busca e o acesso à informação já não representa um grande problema e todo o conteúdo disponível pode ser um grande facilitador no processo de aprendizagem, na busca de soluções e referências. Contudo, o excesso de informação 
pode ter o mesmo efeito que pouca informação, e, se antes o problema era a dificuldade de acesso, hoje o problema é a dificuldade de processamento. Mais do que nunca, o professor tem de exercer o seu papel não apenas na transmissão do co nhecimento, mas como um guia que orienta os alunos a buscar, relacionar e fazer uso das informações para suporte no seu aprendizado.

Uma questão pendente, no entanto, é como fazer essas informações chegarem no ambiente de ensino, já que a prática pedagógica do instrumento ainda é muito pautada pela informalidade, realizada na transmissão mestre-aprendiz e baseada em experiências pessoais. A formação de professores para o ensino da performance e a pedagogia do instrumento ainda é algo pequeno e recente no país. Em sua tese de pósdoutorado sobre a pedagogia da performance, Sonia Ray (2015) discute esse assunto e mostra que quase não há cursos específicos para formação desse profissional e grande parte das universidades nacionais oferece poucas disciplinas sobre o tema.

Com relação à experiência prática realizada, foi possível notar que as atividades de planejamento e a avaliação foram fundamentais para a produtividade ao longo do processo, trazendo impacto positivo no desenvolvimento musical. 0 planejamento antecipado do que precisava fazer e o estabelecimento das metas para as sessões de estudo permitia aproveitar melhor o tempo e facilitar a concentração no trabalho. A avaliação da semana ajudava a rever e organizar o trabalho de maneira mais realista e objetiva, permitindo julgar adequadamente o estágio de desenvolvimento das obras, encontrar dificuldades no processo de estudo e perceber o que estava sendo negligenciado.

Há, no entanto, algumas limitações nessa experiência prática. Não é possível caracterizar essa etapa como uma pesquisa experimental, já que não inclui os critérios metodológicos que seriam necessários a tal trabalho. Por esse motivo, foi realizado apenas na forma de memorial de estudo, o qual relata a aplicação das orientações levantadas na pequisa teórica, sendo o processo registrado em gravações, vídeos e diários. Essa etapa teve também a função dupla de permitir reflexão sobre as implicações práticas do assunto discutido e suprir as exigências do curso de performance, no qual a investigação teórica deve se relacionar com a execução do pesquisador. 
Durante a experiência, nem todas as estratégias estudadas foram usadas de maneira sistemática e equilibrada, apesar de conseguir aplicar várias delas. Ainda assim, os relatórios e gravações de algumas sessões de estudo evidenciam a utilização de vários procedimentos estudados. A duração curta do processo certamente dificultou integrar ao estudo alguns dos objetivos de longo prazo, como aperfeiçoar o elemento expressivo no preparo para a performance que estava ainda em desenvolvimento.

Os registros realizados foram imprescindíveis para a reflexão posterior sobre o processo, já que a avaliação das estratégias aplicadas e do progresso no estudo dependiam destes. Aqui também há outro entrave: só pude avaliar aquilo que eu mesmo consegui registrar. Além disso, para poder analisar com detalhe os comportamentos durante o estudo seria necessário filmar várias sessões durante o processo, investigando com metodologia adequada, as estratégias utilizadas, o controle da atenção e outros processos. Para conseguir fazer isso, além de ser necessário maior conhecimento no que se refere a observação e análise comportamental, teria que suprir uma demanda de trabalho que não seria exequível dentro do mestrado. Essas limitações dificultaram a análise da funcionalidade do processo mas também tornam a experiência próxima de uma situação real, já que qualquer outro indivíduo nas mesmas condições e com os mesmos recursos teria limitações semelhantes no que diz respeito a observação do próprio estudo.

Importante dizer que não é de interesse desse trabalho estabelecer relações causais entre uma abordagem particular de estudo e a melhora do nível de performance. O período de experimentação dessa abordagem foi relativamente curto (12 semanas), visto que frequentemente são necessários meses de trabalho para preparar a performance de uma obra complexa. Creio que seria necessário também mais de um recital, de forma que as falhas do primeiro recital pudessem ser corrigidas, permitindo também uma comparação e uma melhor análise sobre a incidência dessa abordagem na performance. Além disso, a implementação de novos hábitos e abordagens no estudo é um processo longo e seria necessário mais tempo até identificar qual forma de planejamento poderia adequar melhor às características pessoais de trabalho. Como alternativas futuras para a prática, tentaria realizar planos mais simples, revisões de frequência menor (semanal, quinzenal) ou diferentes estratégias para modificar e integrar novos hábitos à rotina. 
Para estudantes violonistas que estejam em fase de formação, que procuram melhorar a maneira de estudar e identificar lacunas na prática individual, o ato de registrar por escrito as metas, estratégias de estudo e reflexões sobre a atividade pode ser um hábito importante a se cultivar (como sugerem várias das referências citadas no trabalho, da pesquisa e da área musical). Naturalmente, ao atingir um alto nível de expertise é provável que a maneira de estudar tenha que se adaptar a outras exigências e talvez o planejamento não seja feito da mesma forma, já que o músico terá desenvolvido maneiras particulares de trabalhar, adquirido um amplo conhecimento de estratégias e uma melhor capacidade de autoavaliação.

Um ponto de partida para avaliar os comportamentos de estudo é através dos questionários, como o elaborado por Araújo (2015), que foi utilizado nesta pesquisa e que investiga o comportamento autorregulado nos músicos. Outra referência é Hatfield e Lemyre (2016) que elaborou um questionário que foi usado para traçar um perfil dos sujeitos de sua pesquisa com relação preparo para performance (performance profile), onde ficavam evidentes pontos fortes e fracos dos participantes. Estas ferramentas podem ajudar a ter um panorama dos hábitos de estudo e guiar a implementação de novas abordagens.

O uso da autorregulação e das orientações aqui discutidas não visam reduzir ou sistematizar o processo de experimentação e pesquisa inerentes à prática artística. 0 próprio processo de escolher estratégias, aplicar e avaliar o seu funcionamento é um processo cíclico de experimentação. Se o resultado é bom, mantém-se. Do contrário, altera-se o plano. Todos fazem isso de alguma maneira ao estudar. As dificuldades podem estar no conhecimento ou escolha das estratégias, em não estabelecer metas claras, problemas na execução do plano (concentração, monitoramento) ou, de maneira crucial, na autoavaliação dos resultados e da maneira de estudar. Ao ampliar sua capacidade metacognitiva, conhecendo melhor o processo de estudo e as características pessoais de trabalho, pode-se investigar onde estão as principais lacunas, mudar a abordagem de trabalho e procurar ajuda externa quando necessário. Fazendo isso, acredito ser possível melhorar a postura frente ao estudo, desenvolver de maneira mais eficiente as habilidades musicais e aperfeiçoar sua produção artística.

Por fim, o assunto deste trabalho pode ter vários outros desdobramentos. Por exemplo: de que maneira incluir novos hábitos na rotina de estudo? Como uso de 
ferramentas digitais pode colaborar no aperfeiçoamento do estudo? Qual o impacto dessa abordagem na performance a longo prazo? Como o professor pode promover a autonomia no aluno em diferentes etapas da formação? Espera-se, portanto, que esse material sirva de referência não apenas para estudantes e professores, mas também para outras pesquisas e que colabore para investigação sobre o ensino e aprendizagem da performance musical. 


\section{REFERÊNCIAS BIBLIOGRÁFICAS}

AGUADO, D. Nuevo método para guitarra. Madrid: Benito Campo, 1843.

ALVES, A. C. Expertise na clarineta: possibilidades de construção da performance musical de "alto nível”. 2013. 103 f. Dissertação (Mestrado em Música). Universidade de Brasília, Brasília, 2013.

ARAÚJO, M. V. Estratégias de estudo utilizadas por dois violonistas na preparação para a execução musical da Elegy (1971) de Alan Rawsthorne. 2010. 138 f. Dissertação (Mestrado em Música). UFRGS, Porto Alegre, 2010.

. Comportamentos autorreguladores e experiências de fluxo na prática musical: Um Inquérito Com Performers De Nível Avançado. 2015. 228 f. Doutorado em Música (Tese). Departamento de Comunicação e Arte, Universidade de Aveiro, 2015.

AZZI, R. G.; POLYDORO S. A. J. Autorregulação da aprendizagem na perspectiva da teoria sociocognitiva: introduzindo modelos de investigação e intervenção. Revista Psicologia da Educação, São Paulo, n. 29, p. 75-94, 2009.

BANDURA, A.; AZZI, R. G.; POLYDORO, S.. Teoria social cognitiva: conceitos básicos. Porto Alegre: Artmed, 2008.

BARROS, L. C. A pesquisa empírica sobre o planejamento da execução instrumental: uma reflexão crítica do sujeito de um estudo de caso. 2008. 265 p. Tese (Doutorado em Música). UFRGS, Porto Alegre, 2008

Retrospectiva histórica e temáticas investigadas nas pesquisas empíricas sobre o processo de preparação da performance musical. Per Musi, Belo Horizonte, n.31, p.284-299, 2015.

BARRY, N. The effects of practice strategies, individual differences in cognitive style, and gender upon technical accuracy and musicality of student instrumental performance. Psychology of Music, v. 20 n.2, p.112-123, 1992.

BARRY, N.H.; HALLAM, S. Practice. In: PARNCUTT, R., \& MCPHERSON, G.E (Eds.). The science and psychology of music performance. Oxford: University Press, 2002, p. 151165.

BJORK, E. L.; BJORK, R. A. Making things hard on yourself, but in a good way: Creating desirable difficulties to enhance learning. Psychology and the real world: Essays illustrating fundamental contributions to society, p. 56-64, 2011.

BORÉM, F.; RAY, S. Pesquisa em Performance Musical no Brasil no século XXI: problemas, tendências e alternativas. In: Simpósio Brasileiro de Pós-Graduandos em Música (2.), 2012, Rio de Janeiro. Anais do II SIMPOM, Rio de Janeiro: UNIRIO, 2012. p. 121-168. 
BORUCHOVITCH, E. Autorregulação da aprendizagem: contribuições da psicologia educacional para a formação de professores. Psicologia Escolar e Educacional, Maringá, v. 18, n.3, p. 401-409, Dez 2014.

CAMARGO, G. A guitarra do século xix em seus aspectos técnicos e estilístico-históricos a partir da tradução comentada e análise do "Método para guitarra" de Fernando Sor. 2005. 188 f. Dissertação (Mestrado em Música). USP - São Paulo, 2005.

CARLEVARO, A. Escuela de la Guitarra: Exposición de la teoría instrumental. Buenos Aires: Barry Editorial, 1979.

CARULLI, F. Metodo completo per chitarra Op.27. Milão: Lucca, c.a. 1850. Disponível em: <http://imslp.org/wiki/M\%C3\%A9thode compl\%C3\%A8te\%2C 0p.27 (Carulli \%2C Ferdinando) > Acesso em: 10 nov. 2015.

CAVALCANTI, C. R. P. Auto-regulação e prática instrumental: um estudo sobre as crenças de auto-eficácia de músicos instrumentistas. 2009. 157 f. Dissertação (Mestrado em Música). Setor de Ciencias Humanas, Letras e Artes, UFPR, Curitiba, 2009.

CHAFFIN, R; LEMIEUX, A. F. General Perspectives on achieving musical excellence. In: WILLIAMON, A. Musical excellence: strategies and techniques to enhance performance. Oxford: Oxford University Press, 2004. p. 19-39.

CONNOLLY, C.; WILlLIAMON, A. Mental Skills Training. In: Williamon, A (ed.). Musical Excellence: strategies and techniques to enhance performance. New York: Oxford University Press, 2004, p 221-245.

DANIEL, R. Self-assessment in performance. British Journal of Music Education. Vol. 18, $\mathrm{n}^{\circ} 3$, p. 215-226, 2001.

ERICSSON, K. A.; KRAMPE, R. T.; TESCH-HÖMER, C. The role of deliberate practice in the acquisition of expert performance. Psychological Review, v. 100, n. 3, p. 363-406, 1993.

FERNANDEZ, E. Técnica, Mecanismo, Aprendizagem: Una investigación sobre cómo llegar a ser guitarrista. Montevideo: Ediciones ART, 2000.

FLESCH, C. The Art of Violin Playing. Carl Fischer Inc. New York, 1939.

FREIRE, L. G. L. Auto-regulação da aprendizagem. Ciências \& Cognição, Rio de Janeiro, v. 14, n. 2, p. 276-286, 2009.

GABRIELSSON, A. Music performance research at the millennium. Psychology of Music, v. 31, p.221-272, 2003.

GALAMIAN, I. Principles of Violin Playing and Teaching. Englewood Cliffs, NJ: Prentice Hall, 1962.

GALVÃO, A. Cognição, emoção e expertise musical. Psicologia: Teoria e Pesquisa, Brasília, v. 22, n. 2, p. 169-174, Agosto 2006.

GERLE, R. The art of practicing the violin. London: Stainer \& Bell, 1983. 
GIESEKING, W.; LEIMER, K. Piano Technique. New York: Dover Publications, 1972.

GINSBORG, J. Strategies for memorizing music. In: In: WILLIAMON, A. Musical excellence: strategies and techniques to enhance performance. Oxford: Oxford University Press, 2004. p. 123-141.

GLISE, A. Classical Guitar Pedagogy: a handbook for teachers. Pacific: MelBay, 1997.

GRUSON, L. Rehearsal skill and musical competence: does practice makes perfect? In: SLOBODA, J. Generative Processes in Music: The Psychology of Performance, improvisation and Composition. Oxford: Clarendon Press, 1988, p. 91-112.

HALLAM, S. Professional musicians' approaches to the learning and interpretation of music. Psychology of Music, v. 21, n. 2, pp. 111-128, 1995.

The development of metacognition in musicians: Implications for education.

British Journal of Music Education, v. 18, pp. 27-39, 2001.

HALLAM, S.; BAUTISTA; A. Processes of Instrumental Learning: The Development of Musical Expertise. In: MCPHERSON, G.; WELCH, G.F. The Oxford Handbook of Music Education. Oxford: Oxford University Press, 2012. p.658-676.

HATFIELD, J.L.; HALVARI, H.; LEMYRE, P-N.. Instrumental practice in the contemporary music academy: A three-phase cycle of Self-Regulated Learning in music students. Musicae Scientiae, p.1-22, 2016. Disponível em: <https://doi.org/10.1177/1029864916658342> Acesso em: 17 nov. 2016.

HATFIELD, J.L.; LEMYRE; P-N.. Foundations of Intervention Research in Instrumental Practice. Front. Psychol. Vol: 6, 2016. Disponível em: <https://doi.org/10.3389/fpsyg.2015.02014 >. Acesso em: 05 out. 2016.

IZNAOLA, R. On Praticing: a manual for students of guitar performance. Pacific, MO: Mel Bay Publications, 2000.

JORGENSEN, H. Strategies for individual practice. In: WILLIAMON, A. Musical excellence: strategies and techniques to enhance performance. Oxford: Oxford University Press, 2004. p. 85-103.

KAMINSKI, L. C. Preparação e planejamento da performance do violonista: Estudo da obra homenagem a Villa-Lobos Op. 46 de Marlos Nobre. 2012. 77p. Dissertação (Mestrado em Música) UFG - Goiânia, 2012.

KAPLAN, J. A. Teoria da Aprendizagem Pianística. 2a edição. ed. Porto Alegre: Editora Movimento, 1987.

KENNY, W. E. The effect of metacognitive strategy instruction on the performance proficiency and attitude toward practice of beginning band students. Tese (Doutorado). Illinois: University of Illinois, 1992.

KLICKSTEIN, G. The Musician's Way: a Guide to Practice, Performance, and Wellness. Oxford: Oxford University Press, 2009. 
LEHMANN, A.C.; JORGENSEN, H. Practice. In: MCPHERSON, G.; WELCH, G.F. The Oxford Handbook of Music Education. Oxford: Oxford University Press, 2012. p.677-693.

LEON-GUERRERO, A. Self-regulation strategies used by student musicians during music practice. Music Education Research, Vol. 10, No. 1, p. 91-106, 2008.

MCPHERSON, G. E.; ZIMMERMAN, B. J. Self Regulation of musical learning. In: COLWELL, R.; WEBSTER P. (eds). MENC Handbook of Research on Music Learning. Oxford: Oxford University Press, 2011. p. 130-175.

MELLO, F. M. Preparação da performance de música de câmara com violão: o uso do corpo no repertório com técnicas estendidas. 2015. 93 p. Dissertação (Mestrado em Música). UNESP, São Paulo, 2015.

MENDONÇA, M. O. Representações mentais na performance violonística. 2015. 177p. Dissertação (Mestrado em Música). Dissertação (Mestrado). Universidade Federal de Goiás, Escola de Música e Artes Cênicas (EMAC), Programa de Pós-Graduação em Música, Goiânia, 2015.

MIKSZA, P. The development of a measure of self-regulated practice behavior for beginning and intermediate instrumental music students. Journal of Research in Music Education, no 59, Vol. 4, p. 321-338, 2011. Disponível em: <http://jrm.sagepub.com/content/59/4/321.full.pdf+html>. Acesso em: 02 nov. 2014.

The effect of self-regulation instruction on the performance achievement, musical self-efficacy, and practicing of advanced wind players. Psychology of Music, Vol 43, Issue 2, p. 219 - 243, 2013. Disponível em: < https://doi.org/10.1177/0305735613500832> Acesso em: 07 jul. 2015.

MONTALVO, F. T.; TORRES, M. C. G. El aprendizaje autorregulado: presente y futuro de la investigación. Electronic journal of research in educational psychology, v. 2, n. 3, p. 1-34, 2004.

NIELSEN, S.. Regulation of learning strategies during practice: a case study of a Church organ student preparing a musical work for performance. Psychology of Music, v.27, p.218-229, 1997.

Self-regulating learning strategies in instrumental music practice. Music Education Research v. 3, n. 2, p. 156-157, 2001.

PARKES, K. A. Recent Research in Applied Studio Instruction: Practice Time and Strategies. The Journal of Research in Music Performance, 2010. Disponível em: <http://dx.doi.org/10.21061/jrmp.v0i0.729> Acesso em: 05 jun. 2016.

POLYDORO, S. A. J. \& AZZI, R. Autorregulação: aspectos introdutórios. In: BANDURA, A.; AZZI, R.; POLYDORO, S. A. J. (orgs.). Teoria Social Cognitiva: conceitos básicos. Porto Alegre, Editora Artmed, 2008, p.149-164.

PROVOST, R. The Art and Technique of Practice. London: Music Sales, 1992. 
The Art and Technique of Performance. São Francisco: GSP, 1994.

PUJOL, E. Escuela razonada de guitarra (Libros 1-4). Buenos Aires: Ricordi Americana, 1933.

RAY, S. Pedagogia da performance musical. 84 p. Tese (Pós-doutorado). Escola de Música e Artes Cênicas, UFG, Goiânia, 2015.

REID, S. Preparing for Performance. In: RINK, J. Musical Performance: a guide to understanding. New York: Cambrige University Press, 2002, p.102-112.

RICHERME, C. A técnica pianística: uma abordagem científica. São João da Boa Vista, SP: AIR Musical Editora, 1997.

RYAN, L. F. The Natural Classical Guitar: The Principles of Effortless Playing. Westport, CT: Bold Strummer Ltd, 1991.

SALGADO, R. P. A preparação da performance musical de quarteto de violões. 121 p. Dissertação (Mestrado em Música). UNESP, São Paulo, 2015.

SANTOS, R. A. T.; HENTSCHKE, L. A perspectiva pragmática nas pesquisas sobre prática instrumental. Per Musi, Belo Horizonte, n. 19, p. 72-82, 2009.

SILVA, C.; SCARDUELLI, F. A autorregulação da aprendizagem aplicada ao ensino de técnica de violão na graduação. XXIII Congresso da Anppom, Brasil, jun 2013. Disponível em:

<http://www.anppom.com.br/congressos/index.php/23anppom/Natal2013/paper/vie $\underline{\mathrm{w} / 2159}>$. Data de acesso: 04 Mar. 2016.

SILVA, C. Ensino de instrumento - violão - nos cursos de licenciatura em música: uma proposta a partir da autorregulação da aprendizagem. 2016. 109 p. Dissertação (Mestrado em Música). UNICAMP, Campinas, 2016.

SLOBODA, J.A.; DAVIDSON, J.W.; HOWE, M.J.A.; MOORE, D.G. The role of practice in the development of performing musicians. British Journal of Psychology, v. 87, p.287-309, 1996.

SLOBODA, J.A. Exploring the musical mind: Cognition, emotion, ability, function. Oxford: Oxford Univesity Press, 2005.

STERNBERG, R.J. Psicologia Cognitiva. Tradução da 5a. ed. São Paulo: CENGAGE, 2010.

TEnNANT, S. Pumping Nylon: The Classical Guitarist's Technique Handbook. Los Angeles: Alfred Music, 1995.

WILLIAMON, A.; VALENTINE, E. Quantity and quality of musical practice as predictors of perfomance quality. British Journal of Psychology, v. 91, p. 353-376, 2000.

WILLIAMON, A. Musical excellence: strategies and techniques to enhance performance. Oxford: Oxford University Press, 2004. 
ZIMMERMAN, B. J.. Attaining self-regulation: A social cognitive perspective. In: M. Boekaerts, P. R. Pintrich, \& M. Zeidner (Eds.). Handbook of self-regulation, 2000, p. 1339.

Becoming a Self-Regulated Learner: An Overview. Theory Into Practice. v. 41, n.2, 2002, p. 64-70. 


\section{ANEXOS}

1 - Quadro de frequência diária, mostrando as obras foram estudadas em cada dia da etapa prática do trabalho (divido em 3 partes: Fevereiro, Março e Abril).

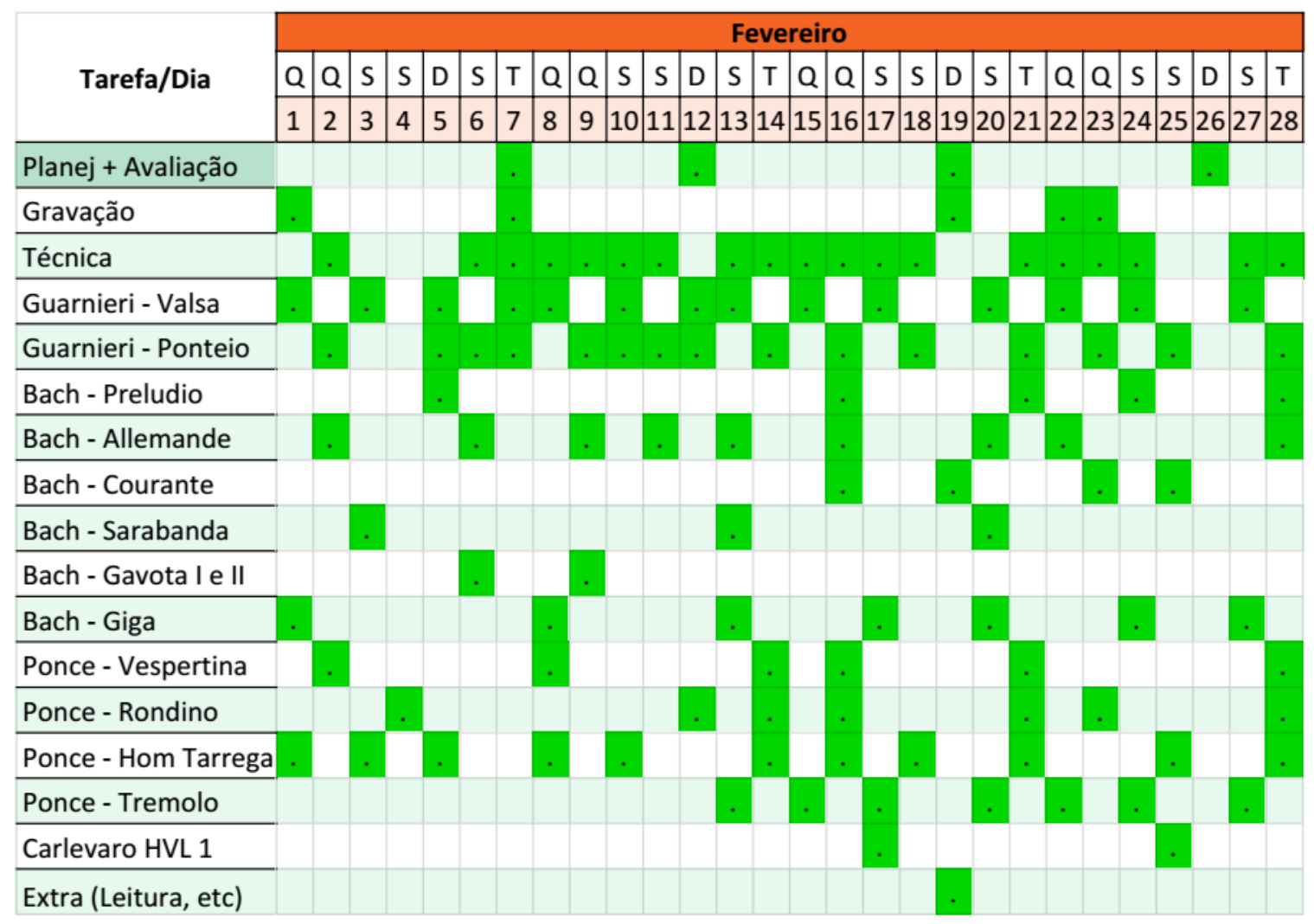




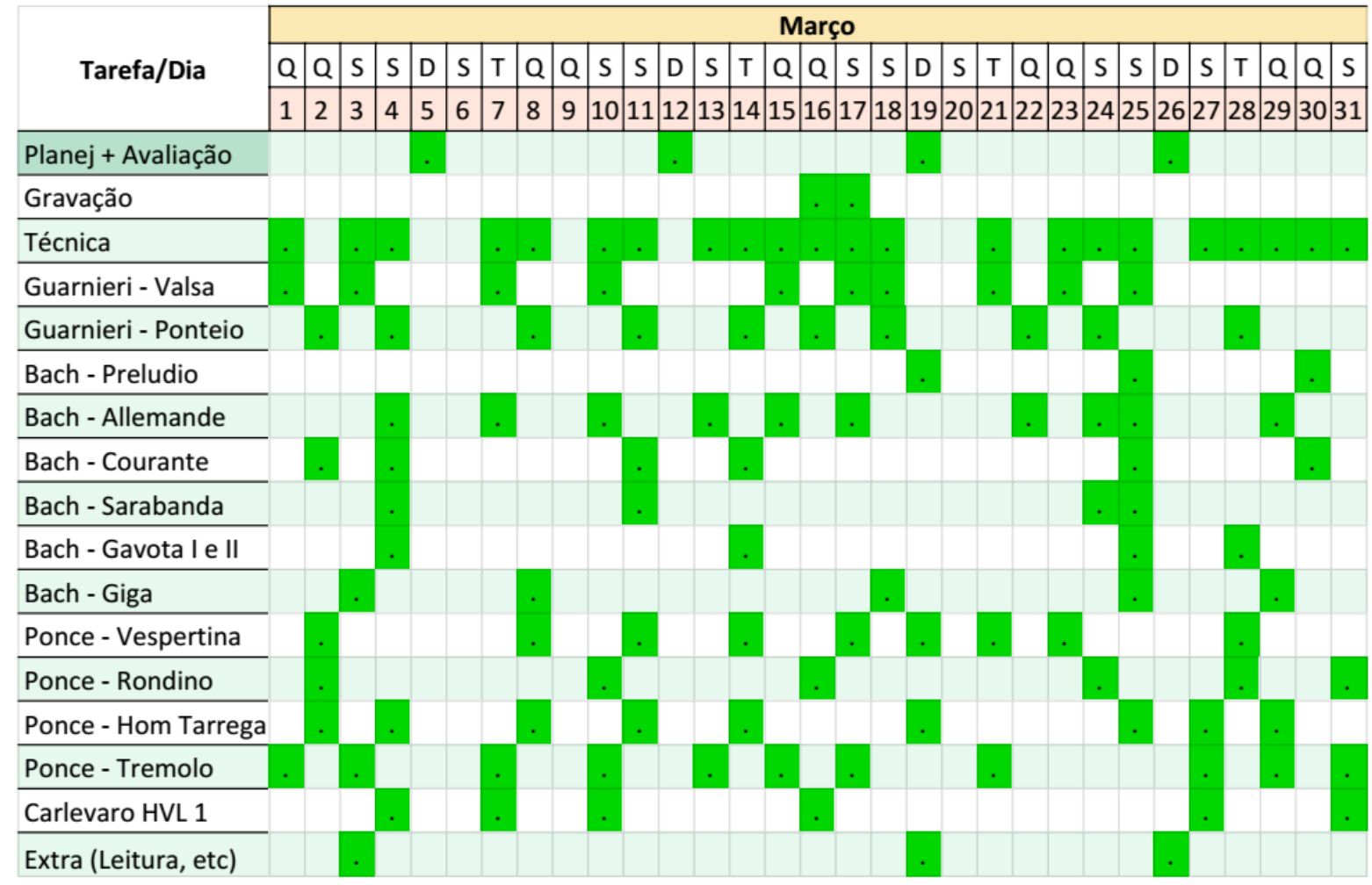

\begin{tabular}{|c|c|c|c|c|c|c|c|c|c|c|c|c|c|c|c|c|c|c|c|c|}
\hline \multirow{3}{*}{ Tarefa/Dia } & \multicolumn{19}{|c|}{ Abril } & \multirow{3}{*}{$\begin{array}{l}\text { Total de } \\
\text { sessões }\end{array}$} \\
\hline & $\mathrm{S}$ & $\mathrm{D}$ & $\mathrm{s} 1$ & $\mathrm{~T}$ & $Q$ & $\mathrm{~s}$ & $\mathrm{~s}$ & 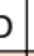 & $\mathrm{S}$ & $\mathrm{T}$ & $Q \mathbf{Q}$ & $\begin{array}{ll}\mathrm{a} & \mathrm{S} \\
\end{array}$ & $\mathrm{s}$ & \begin{tabular}{l|l} 
& $S$ \\
\end{tabular} & \begin{tabular}{l|l}
$\mathrm{S}$ & $\mathrm{T}$ \\
\end{tabular} & $\mathrm{Q} Q \mathrm{Q}$ & $\begin{array}{lll}2 & 5 & 5 \\
\end{array}$ & $S D$ & \begin{tabular}{|l|l}
$D$ & $S$ \\
\end{tabular} & \\
\hline & 1 & 2 & $3 \mid<$ & \begin{tabular}{l|l}
4 & 5 \\
\end{tabular} & 6 & 7 & 8 & & 10 & & & & 15 & & \begin{tabular}{l|l}
17 & 18 \\
\end{tabular} & \begin{tabular}{|l|l|l|}
19 & 20 \\
\end{tabular} & 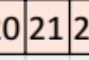 & 222 & \begin{tabular}{|l|l|}
23 & 24 \\
\end{tabular} & \\
\hline Planej + Avaliação & & & & & & & & & & & & & & & & & & & & 11 \\
\hline Gravação & & & & & & & & & & & & & & & & & & . & & 9 \\
\hline Técnica & & & & & & & & & & & & & & & & & 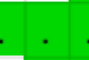 & . & . & 59 \\
\hline Guarnieri - Valsa & & & & & & & & & & & & & & & & & & . & . & 33 \\
\hline Guarnieri - Ponteio & & & & & & & & & & & & & & & & & & . & . & 33 \\
\hline Bach - Preludio & & & & & & & & & & & & & & & & & & . & . & 14 \\
\hline Bach - Allemande & & & & & & & & & & & & & & & & & & . & . & 28 \\
\hline Bach - Courante & & & & & & & & & & & & & & & & & 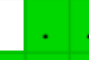 & . & . & 16 \\
\hline Bach - Sarabanda & & & & & & & & & & & & & & & & & . & . . & . & 12 \\
\hline Bach - Gavota I e II & & & & & & & & & & & & & & & & & . &. & . & 14 \\
\hline Bach - Giga & & & & & & & & & & & & & & & & & & . & . & 17 \\
\hline Ponce - Vespertina & & & & & & & & & & & & & & & & & 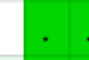 & . & . & 25 \\
\hline Ponce - Rondino & & & & & & & & & & & & & & & & & & . & . & 20 \\
\hline Ponce - Hom Tarrega & & & & & & & & & & & & & & & & & & . & . & 30 \\
\hline Ponce - Tremolo & & & & & & & & & & & & & & & & & & & & 23 \\
\hline Carlevaro HVL 1 & & & & & & & & & & & & & & & & & & . & . & 14 \\
\hline Extra (Leitura, etc) & & & & & & & & & & & & & & & & & & & & 7 \\
\hline
\end{tabular}


2 - Dois excertos do diário de estudos da 6 ${ }^{\mathrm{a}}$ semana da etapa prática, incluindo registros de impressões pessoais e avaliação semanal (divido em 2 partes).

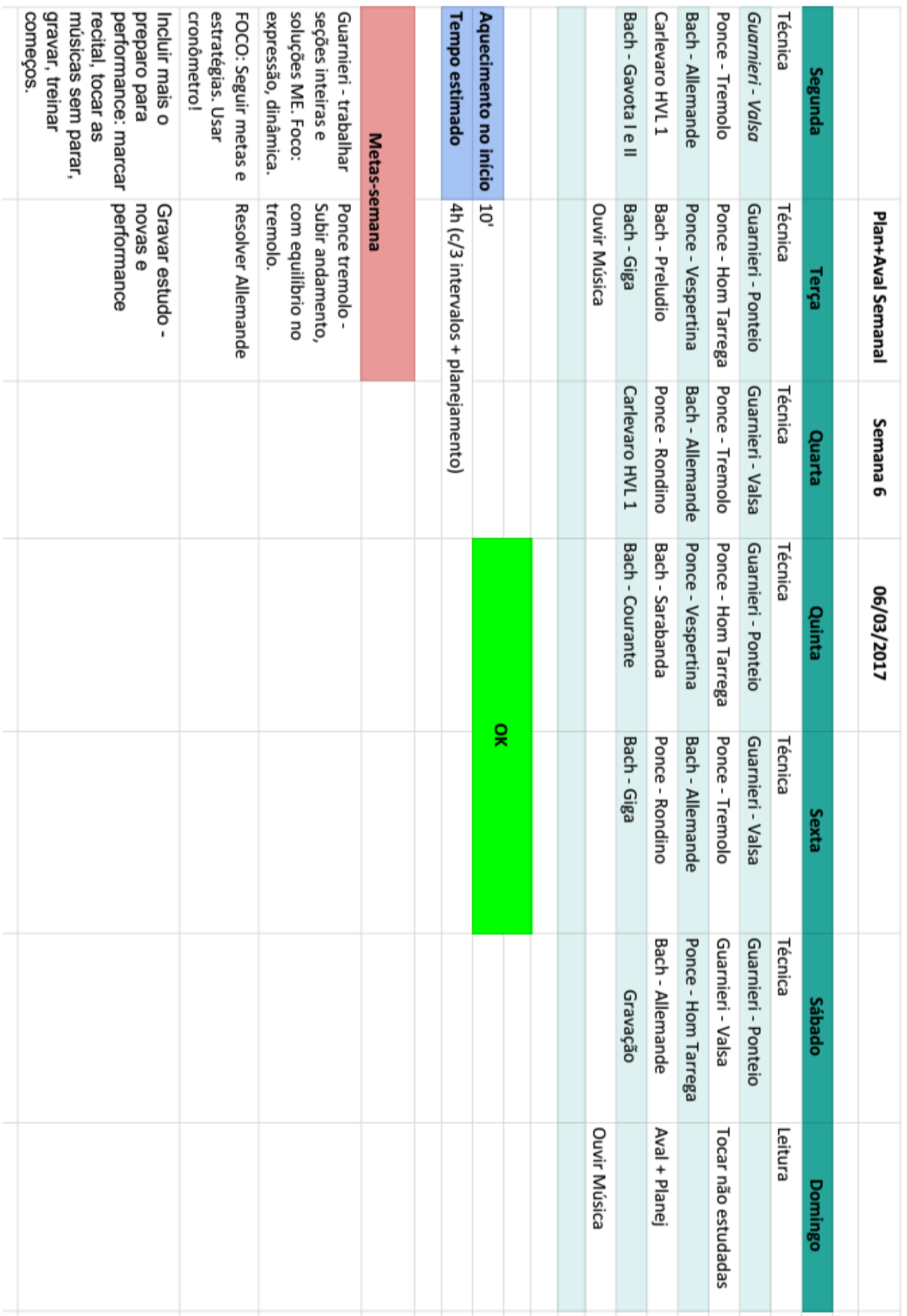



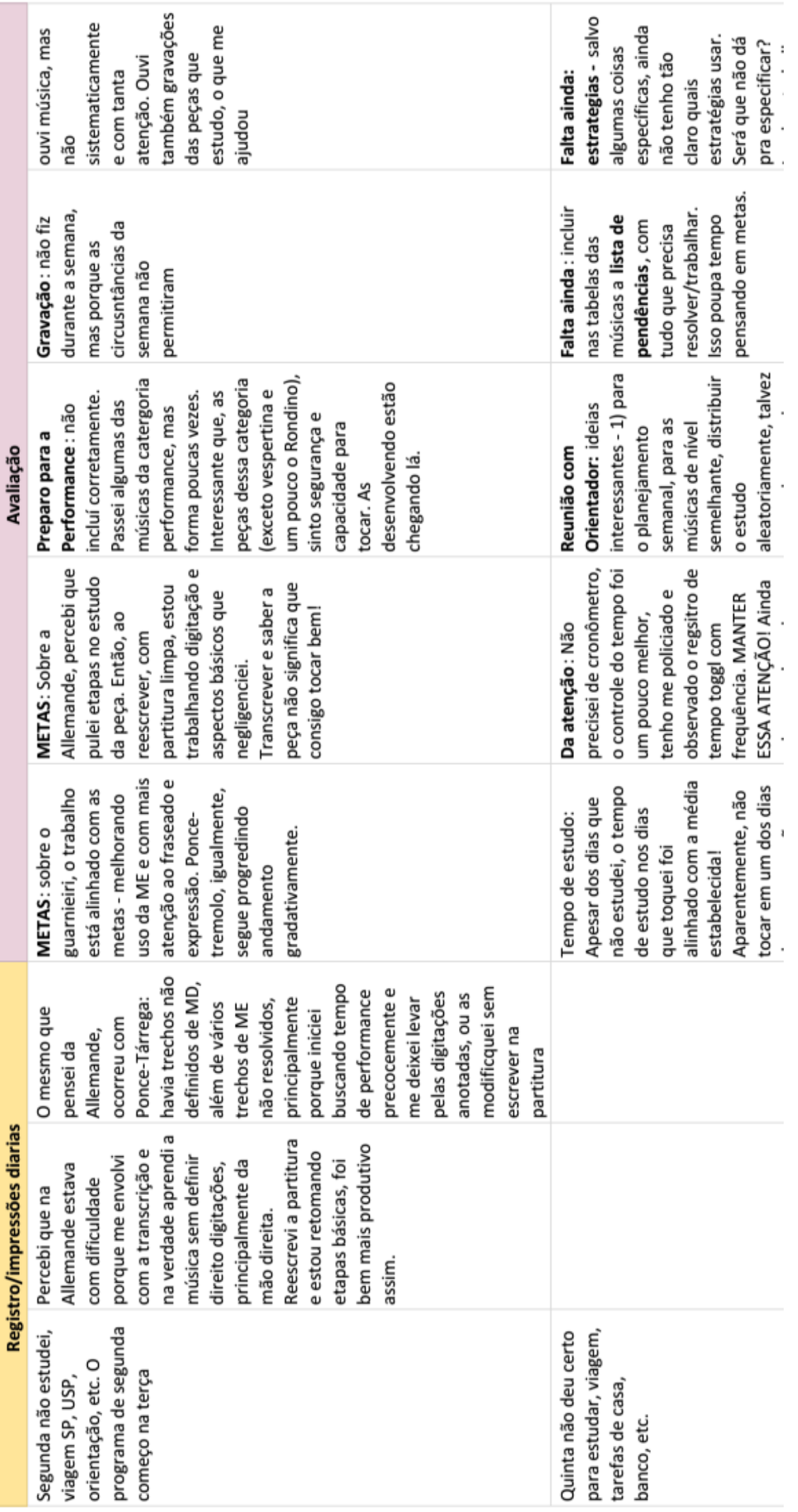
3 - Excertos do diário de estudo de obras da categoria "Em desenvolvimento" (Estudio - Manuel Ponce) e "Performance" (Giga - Bach), respectivamente.

\begin{tabular}{|c|c|c|c|}
\hline \multicolumn{4}{|c|}{ Ponce - Tremolo } \\
\hline Data & Metas (Qual/ O Quê) & Estratégia (Como) & Resultados/Avaliação \\
\hline $13 / 02 / 2017$ & $\begin{array}{l}\text { Revisão geral, sem } \\
\text { tremolo }\end{array}$ & $\begin{array}{l}\text { Lento com partitura, } \\
\text { seções }\end{array}$ & $\begin{array}{l}\text { Revisei geral, lento, tocando como a } \\
\text { intervalos. Seções estavam } \\
\text { marcadas. Trabalhei A e B com } \\
\text { tremolo lento. No tremolo preciso: } \\
\text { evitar acento no anelar, sincronizar } \\
\text { troca de dedos ME. }\end{array}$ \\
\hline $15 / 02 / 2017$ & $\begin{array}{l}\text { Trabalhar seções } \\
\text { complexas (ex: } \\
\text { cromatismo; } \\
\text { agudissimo) }\end{array}$ & $\begin{array}{l}\text { lento, com partitura, } \\
\text { seções, sem tremolo }\end{array}$ & $\begin{array}{l}\text { Toquei seçoes centrais D-G, lento, } \\
\text { sem e com tremolo. Manter atenção } \\
\text { para não acentuar anelar e } \\
\text { sincronizar trocas ME. Foi bom, } \\
\text { compacto, focado, sem exageros. }\end{array}$ \\
\hline $17 / 02 / 2017$ & $\begin{array}{l}\text { Fluidez em seções } \\
\text { iniciais }\end{array}$ & idem & $\begin{array}{l}\text { toquei lento (65) seção inicial e } \\
\text { parte em Maior. O deslocamento } \\
\text { constante do polegar cansa um } \\
\text { pouco, com salto da } 6 \text { a para } 2 \text { a } \\
\text { corda. Não passar de } 15 \text { min nisso. }\end{array}$ \\
\hline $20 / 02 / 2017$ & $\begin{array}{l}\text { Fluidez no final e } \\
\text { cromatismo }\end{array}$ & $\begin{array}{l}\text { lento, metrônomo, } \\
\text { intervalos e tremolo } \\
\text { lento }\end{array}$ & $\begin{array}{l}\text { Fiz o que planejei, pratiquei final e } \\
\text { seção cromatismo. Usei intervalos, } \\
\text { tremolo lento, tocando junto. }\end{array}$ \\
\hline $22 / 02 / 2017$ & $\begin{array}{l}\text { Fluidez seções iniciais, } \\
\text { ligar bem as notas ME }\end{array}$ & $\begin{array}{l}\text { lento, metrônomo } 65- \\
70 \text {, tremolo variado e } \\
\text { em intervalos }\end{array}$ & $\begin{array}{l}\text { OK, fiz o planejado, parece mais } \\
\text { preciso e fácil de controlar o } \\
\text { tremolo. Atenção: aumentar pulso } \\
\text { aos poucos ao longo dos dias (65-70- } \\
75 \text { ) }\end{array}$ \\
\hline
\end{tabular}




\begin{tabular}{|c|c|c|c|}
\hline \multicolumn{4}{|r|}{ Bach - Giga } \\
\hline Data & Metas (Qual/ O Quê) & Estratégia (Como) & Resultados/Avaliação \\
\hline $01 / 02 / 2017$ & $\begin{array}{l}\text { Revisão geral, melhorar } \\
\text { trechos críticos, definir } \\
\text { contrastes e dinâmicas }\end{array}$ & $\begin{array}{l}\text { Estudo lento, } \\
\text { seções, testar } \\
\text { ideias }\end{array}$ & $\begin{array}{l}\text { Toquei lento parte A e B; Spots: c. } 13 \\
\text { e finais; Nova digitação final c. } 65 \text {; } \\
\text { Atenção ao dedo } 2 \text {. Vou fazer } \\
\text { repetição variada? }\end{array}$ \\
\hline $08 / 02 / 2017$ & $\begin{array}{l}\text { Trabalhar digitação nova, } \\
\text { revisar digitação MD, } \\
\text { melhorar spots }\end{array}$ & Lento, seções & $\begin{array}{l}\text { no fim do estudo, a noite, mão } \\
\text { cansada e corpo idem. Revisei a } \\
\text { digitação nova e achei outra melhor. } \\
\text { Passei seções para revisão. }\end{array}$ \\
\hline $13 / 02 / 2017$ & $\begin{array}{l}\text { revisão digitação nova, } \\
\text { spots, exagerar } \\
\text { contrastes }\end{array}$ & $\begin{array}{l}\text { lento, seções, } \\
\text { testes }\end{array}$ & $\begin{array}{l}\text { estudei digitação nova, spots e } \\
\text { legato nas escalas. Ainda há falta de } \\
\text { sincronia e acentos indevidos em } \\
\text { escalas. Praticar também controle } \\
\text { do andamento }\end{array}$ \\
\hline $17 / 02 / 2017$ & $\begin{array}{l}\text { Controle do andamento } \\
\text { (pulsação), contrastes } \\
\text { mais claros. }\end{array}$ & $\begin{array}{l}\text { Metrônomo, } \\
\text { seções, gravação } \\
\text { se necessário para } \\
\text { ouvir }\end{array}$ & $\begin{array}{l}\text { usei metrônomo e toquei trechos } \\
\text { críticos. O principal é lembrar o } \\
\text { fraseado e posicionar bem ME. } \\
\text { Posso gravar para ouvir }\end{array}$ \\
\hline $19 / 02 / 2017$ & Gravação & & \\
\hline $20 / 02 / 2017$ & $\begin{array}{l}\text { Trabalhar spots, } \\
\text { contrastes mais claros, } \\
\text { ouvir gravação }\end{array}$ & $\begin{array}{l}\text { gravação, spots, } \\
\text { testes }\end{array}$ & $\begin{array}{l}\text { a gravação não estava muito boa, } \\
\text { estava distraído com o barulho. } \\
\text { melhorar precisão nos finais e parte } \\
\text { central de B. }\end{array}$ \\
\hline $24 / 02 / 2017$ & $\begin{array}{l}\text { melhorar precisão nos } \\
\text { finais e parte central de } \\
\text { B. }\end{array}$ & $\begin{array}{l}\text { Lento com } \\
\text { metrônomo } \\
\text { talvez. FOCO! }\end{array}$ & $\begin{array}{l}\text { Passei lento, revisando fraseado, } \\
\text { alinhamento ME. Vai bem, mas o } \\
\text { reflexo para os trechos difíceis } \\
\text { precisa melhorar. Repetir de formas } \\
\text { diferentes. }\end{array}$ \\
\hline
\end{tabular}


4 - Vídeos anexos em DVD e disponível na internet através YouTube. Esse material contém excertos de sessões de estudo, gravações feitas como ensaio geral e trechos do recital realizado no dia 24/04/2017. Estão destacadas nos vídeos algumas estratégias de ensaio utilizadas e/ou dificuldades encontradas durante o trabalho. A lista dos vídeos no DVD com os links para o YouTube é a seguinte:

1) Estudo de Tremolo (Manuel Ponce) - Sessão de estudo.

https://youtu.be/huepHGkgZU4

2) Valsa-Choro 1 (Camargo Guarnieri) - Sessão de estudo.

https://youtu.be/a9X8Dj2v5UU

3) Valsa-Choro 1 (Camargo Guarnieri) - Ensaio geral e recital.

https://youtu.be/hymrD3CL7Uk

4) Homenaje a Tarrega (Manuel Ponce) - Sessão de estudo.

https://youtu.be/Rr-PwQyj6ws

5) Homenaje a Tarrega (Manuel Ponce) - Ensaio geral e recital.

https://youtu.be/eVqcrT7GaSo

6) Ponteio (Camargo Guarnieri) - Sessão de estudo.

https://youtu.be/U5mlLsEMroo

7) Ponteio (Camargo Guarnieri) - Ensaio geral e recital.

https://youtu.be/d1ZMZKDqmU4

8) Giga da Suite 6 (J. S. Bach) - Ensaio geral e recital

https://youtu.be/t3DIwUcPhHU

Link para a lista com todos os 8 vídeos:

https://www.youtube.com/watch?v=huepHGkgZU4\&list=PLigjp9uRaVLDnvB9ge2d7wlhck2-gNMg 
5 - Programa do recital realizado como parte da etapa prática

Departamento de Música da ECA/USP

Auditório Olivier Toni

Dia 24/04/2017, Segunda-feira às $20 \mathrm{~h} 30$

\section{RECITAL \\ Leandro Quintério - violão (Mestrado)}

Programa:

Manuel Ponce (1882-1948)

Dos Viñetas:

- Vespertina

- Rondino

Homenaje a Tárrega

Abel Carlevaro (1916-2001)

- Estudo $n^{\circ} 1$ - Homenaje a Villa-Lobos

Camargo Guarnieri (1907-1993)

- Ponteio

- Valsa-Choro n'1

J.S. Bach (1685-1750)

Suite 6 para violoncelo (BWV 1012)

- Preludio

- Allemande

- Courante

- Sarabanda

- Gavota I e II

- Giga 